\title{
Retention and Success of Hispanic Students in Maryland Community Colleges
}

\author{
Laura Emerson Whitmore Holland \\ West Virginia University
}

Follow this and additional works at: https://researchrepository.wvu.edu/etd

\section{Recommended Citation}

Holland, Laura Emerson Whitmore, "Retention and Success of Hispanic Students in Maryland Community Colleges" (2011). Graduate Theses, Dissertations, and Problem Reports. 3062.

https://researchrepository.wvu.edu/etd/3062

This Dissertation is protected by copyright and/or related rights. It has been brought to you by the The Research Repository @ WVU with permission from the rights-holder(s). You are free to use this Dissertation in any way that is permitted by the copyright and related rights legislation that applies to your use. For other uses you must obtain permission from the rights-holder(s) directly, unless additional rights are indicated by a Creative Commons license in the record and/ or on the work itself. This Dissertation has been accepted for inclusion in WVU Graduate Theses, Dissertations, and Problem Reports collection by an authorized administrator of The Research Repository @ WVU.

For more information, please contact researchrepository@mail.wvu.edu. 
Retention and Success of Hispanic Students in Maryland Community Colleges

Laura Emerson Whitmore Holland, MA

Dissertation submitted to the College of Human Resources and Education at West Virginia University in partial fulfillment

of the requirements for the degree of

\author{
Doctor of Education \\ in \\ Educational Leadership Studies \\ Elizabeth A. Jones, Ph.D., Chair \\ Ernest R. Goeres, Ph.D. \\ George D. Brown, Ed.D. \\ Richard T. Walls, Ph.D. \\ Ann Richards, Ph.D. \\ Department of Educational Leadership Studies \\ Morgantown, West Virginia
}

2011

Keywords: Community College, Hispanic Students

Copyright 2011 Laura Emerson Whitmore Holland, MA 


\begin{abstract}
Retention and Success of Hispanic Students in Maryland Community Colleges Laura Emerson Whitmore Holland, MA
\end{abstract}

The purpose of this study was to explore the educational experiences of community college Hispanic students in Maryland. The researcher interviewed students to determine what programs and services existed in their high school and college environments that assisted them in the transition from secondary education to higher education. Furthermore, the researcher questioned students about the barriers that may have existed when they decided to enter college. Moreover, the researcher asked students about internal and external influences that may have existed when they were making the transition from high school to college. After each interview, the researcher used Jean Phinney’s Multigroup Ethnic Identity Measure to determine students' awareness of their ethnic identities. The researcher used Tinto’s theory of integration and identified emergent themes from students attending these colleges to determine if students were both academically and socially acclimated to the college. 


\section{Acknowledgements}

My husband, Barry, encouraged me to finish this project and supported me throughout the completion of this project. Your patience and tolerance is so appreciated.

To my children, Zachary, Emmy, and Cole. Thank you for giving me the time to complete this dissertation. Thank you for being so patient when I didn't have the time you needed of me. I know this has been a sacrifice for all of you.

To my mom and Woody, who have read over my work and watched my kids for days in a row without complaining. I couldn’t have done it without you.

Jennie Shaffer, who spent countless hours reading my work making suggestions and constantly encouraged me to move forward.

Jay Stickley, who helped so much with the kids while I attended classes and drove to Morgantown.

Kathy Perry, who listened to me complain and also helped me with the kids so I could work.

My friends, Mary Jane, Paula, Yvonne, and Barb and Matt who supported me throughout the school year to get the job done.

Ben Brauer, my colleague, for supporting me throughout this dissertation.

Stacy Boggs, my friend, for encouraging me and guiding me through this project.

Mr. Lewis, my principal, for allowing me time to go to Morgantown to complete this degree.

Beth Lamm, who helped me so much with APA and formatting my paper. I simply could not have done this without you.

Dr. Elizabeth Jones, my committee chairperson, who continued to support me while understanding that I had a full-time family and a full-time job. It has been a journey, but we did it!

Dr. George Brown, my friend and colleague, who constantly reminded me that I could do this.

Dr. Ernie Goeres, who made me understand and apply the rules of APA.

Dr. Ann Richards, committee member, who graciously agreed to serve on my committee, and shares my passion for the special education population.

Dr. Richard Walls, committee member, whose enthusiasm during my prospectus meeting excited me and encouraged me to complete this project. 


\section{Dedication}

This project is dedicated to my dad, Tony Whitmore, and my friend, Bill Simpson, who made me aware of the differences that exist among people and who possessed a love and talent to educate all who entered their classrooms. I thank you both. 
Table of Contents

Chapter One: Introduction and Problem Statement ....................................................

Statement of Problem ...............................................................................

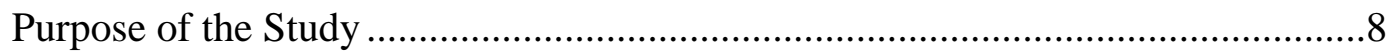

Research Questions .................................................................................9

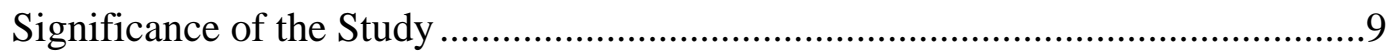

Chapter Two: Review of the Literature .................................................................12

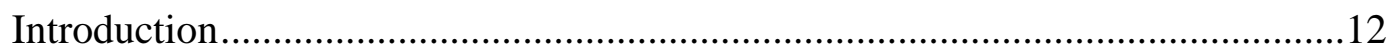

Changing Student Demographics and College Courses ....................................13

Transitioning from Secondary to Higher Education .........................................14

Achieving Goals and Intentions through Community Colleges ..........................17

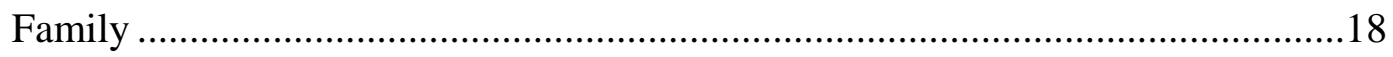

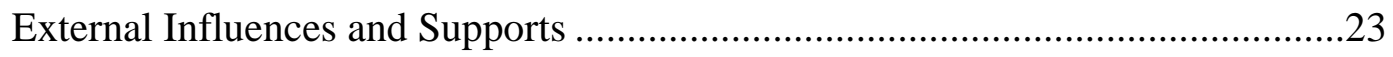

Social Integration: Programs, Services, and Retention Rates..............................31

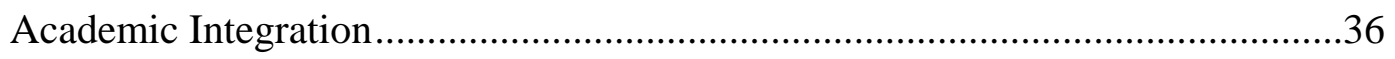

Commitment Toward Attaining Career Goals ..................................................38

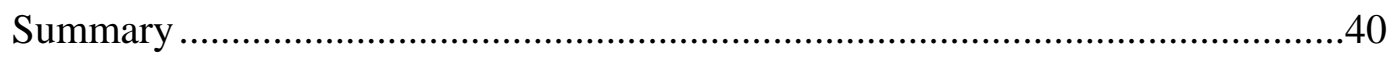

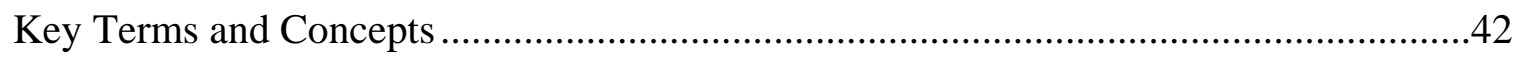

Chapter Three: Research Design and Method ........................................................43

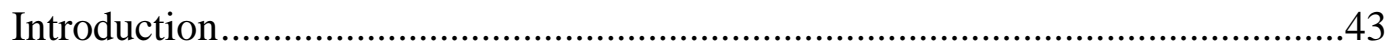

Role of the Researcher ............................................................................44

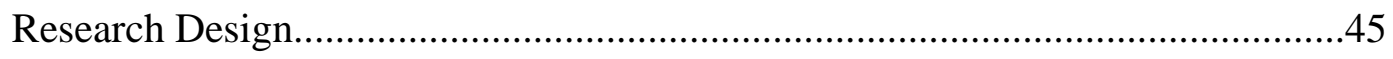

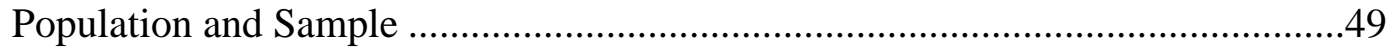




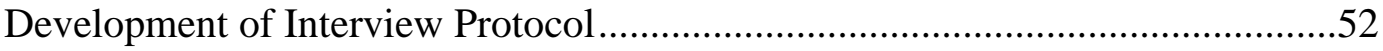

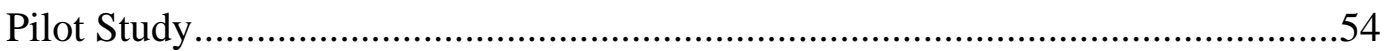

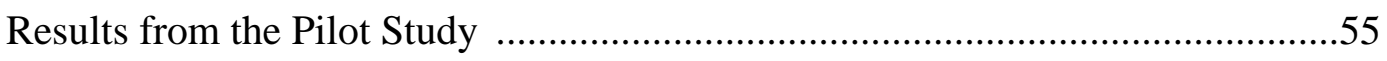

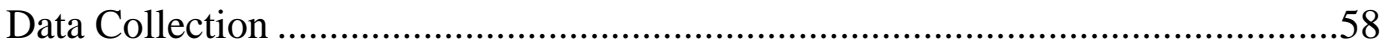

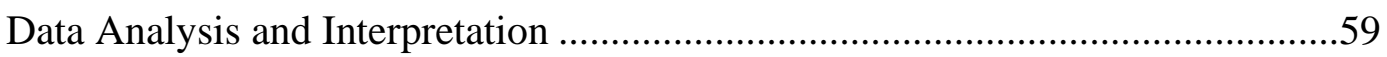

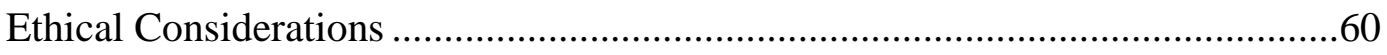

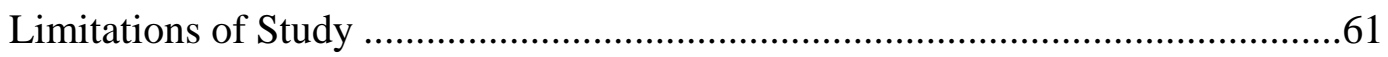

Chapter Four: Knowledge College ......................................................................63

Institutional Background .......................................................................63

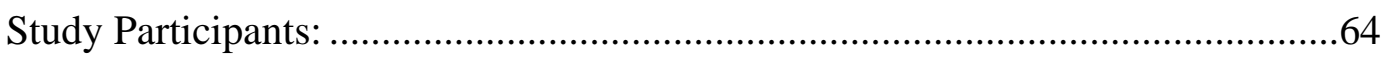

Multigroup Ethnicity Identity Measure .......................................................94

Multigroup Ethnicity Identity Measure Results..............................................94

Chapter Five: Poor Folks College ....................................................................100

Institutional Background ..................................................................... 100

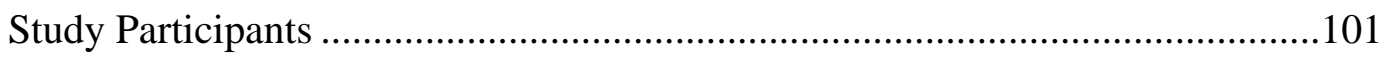

Multigroup Ethnicity Identity Measure ….....................................................123

Multigroup Ethnicity Identity Measure Results.............................................124

Chapter Six: Cross-Site Analysis of Two Maryland Community Colleges ....................130

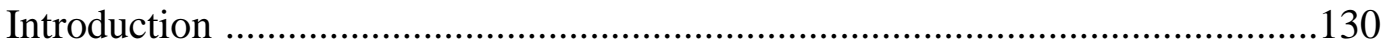

Comparison of Institutional Background ..................................................130

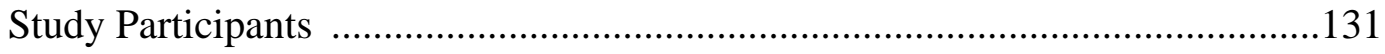

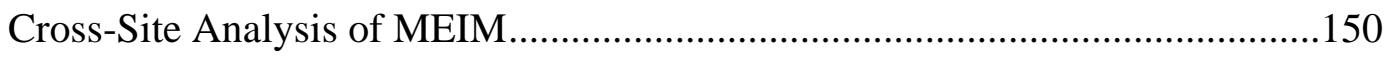

Multigroup Ethnic Identity Results ...........................................................152 
Synthesis of Multigroup Ethnic Identity Measure ........................................156

Chapter Seven: Summary, Conclusion, and Recommendations

for Future Practice and Research .................................................................158

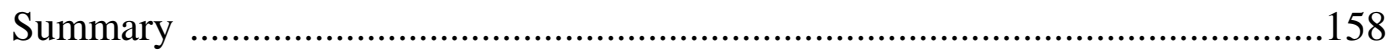

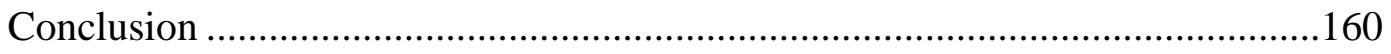

Research Question 1 .....................................................................163

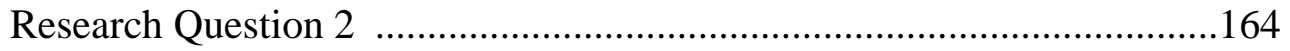

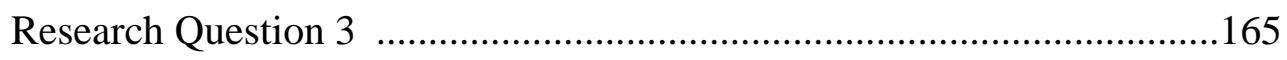

Research Question 4 ......................................................................166

Research Question 5 ................................................................167

Research Question 6 ................................................................168

Research Question 7 ..................................................................169

Recommendations for Future Practice ......................................................169

Recommendations for Future Research ...................................................171

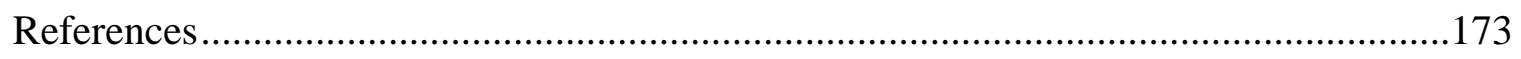

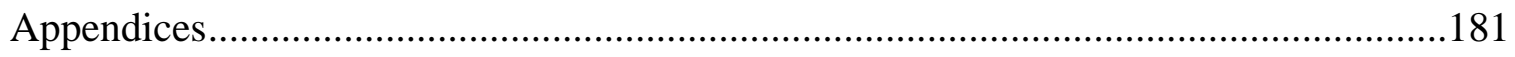


List of Tables

Table 12005 Characteristics of Selected Community College .......................................51

Table 2 Interview Protocol Questions Applying to Research Questions ...........................53

Table 3 Revised Interview Protocol Questions Applying to Research Questions ............57

Table 4 Participants in the Study for Knowledge College.............................................66

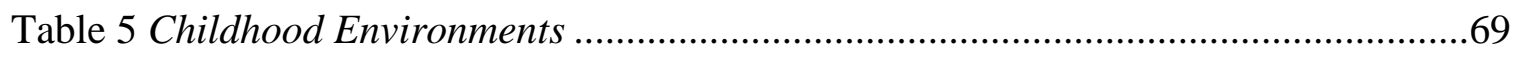

Table 6 Parents’ Educational Backgrounds ...............................................................70

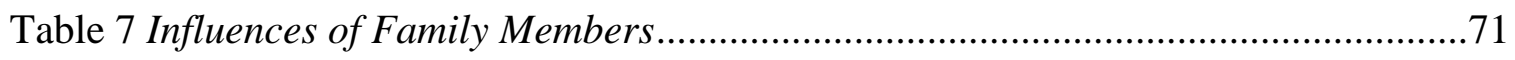

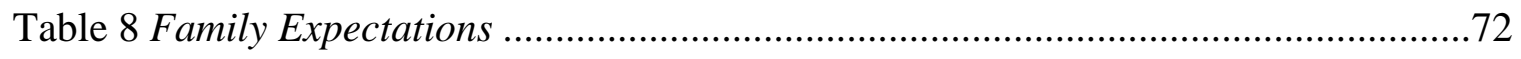

Table 9 Decision to Attend Knowledge College ..........................................................75

Table 10 Challenges Students Encountered ..............................................................77

Table 11 High School Programs and Services ......................................................... 78

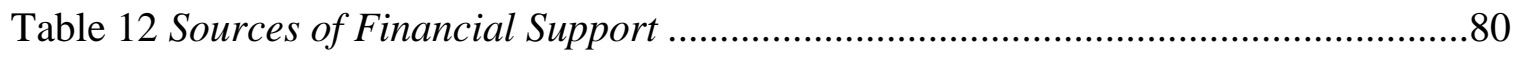

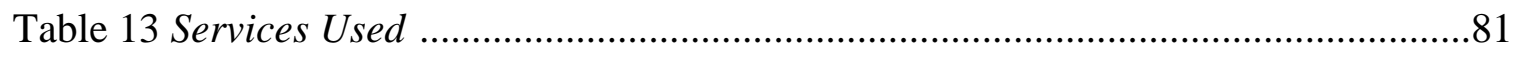

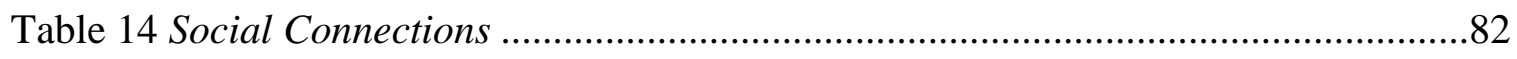

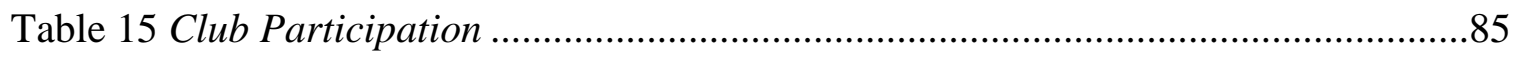

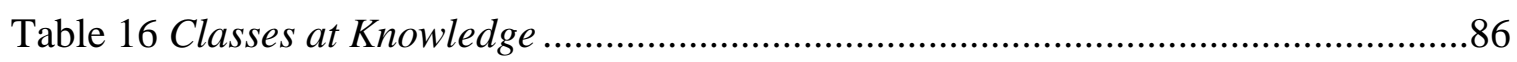

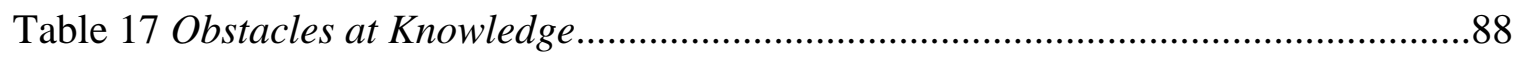

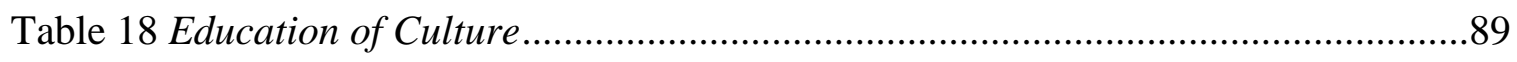

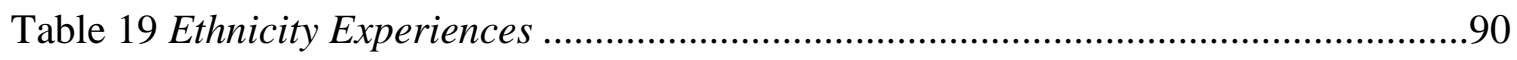

Table 20 Affects of Being Hispanic ........................................................................92

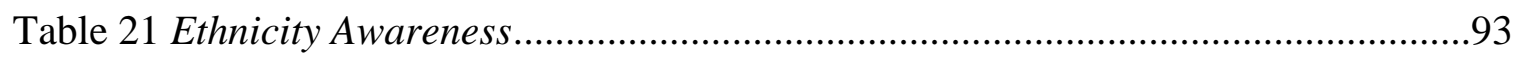

Table 22 Knowledge College MEIM Responses ........................................................95 
Table 23 Knowledge College Students' Ethnicity ............................................................98

Table 24 Knowledge College Father's Ethnicity ...........................................................98

Table 25 Knowledge College Mother's Ethnicity .............................................................99

Table 26 Demographics .............................................................................................102

Table 27 Childhood Environments ..............................................................................104

Table 28 Parents’ Educational Backgrounds ................................................................105

Table 29 Influences to Attend College ..........................................................................106

Table 30 Family Expectations ...............................................................................107

Table 31 Decision to Attend Poor Folks College ………...................................................108

Table 32 Challenges Students Encountered ..................................................................110

Table 33 Programs and Support in High School..........................................................111

Table 34 Receiving Financial Aid...............................................................................113

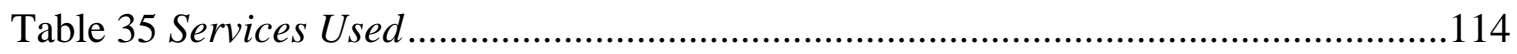

Table 36 Socially Connected …………………………........................................116

Table 37 Club Participation ..............................................................................117

Table 38 Classes at Poor Folks ......................................................................118

Table 39 Obstacles at Poor Folks College …………….............................................119

Table 40 Education of Culture ..................................................................................120

Table 41 Affects of Being Hispanic...........................................................................121

Table 42 Ethnicity Awareness..................................................................................123

Table 43 Poor Folks MEIM Responses ......................................................................125

Table 44 Poor Folks Students’ Ethnicity ...................................................................128

Table 45 Poor Folks Father's Ethnicity .......................................................................128 


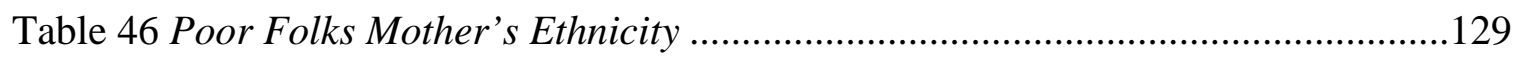

Table 47 Environments Where Students Were Raised ................................................132

Table 48 Parents' Educational Background..............................................................133

Table 49 Most Influential Person .........................................................................134

Table 50 Decision to Attend a Certain College .............................................................135

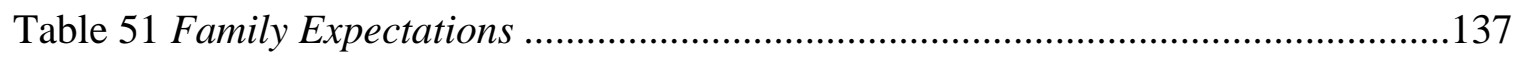

Table 52 Challenges Students Encountered ..............................................................138

Table 53 Help Students Had Transferring from High School to College .........................140

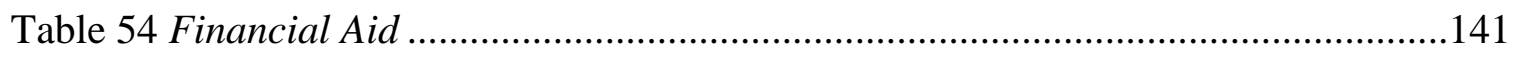

Table 55 Resources Students Used at College ............................................................142

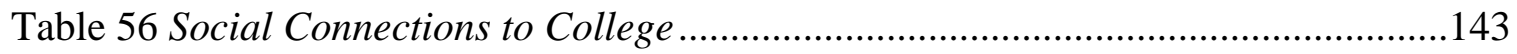

Table 57 Student Participation in Organizations ......................................................145

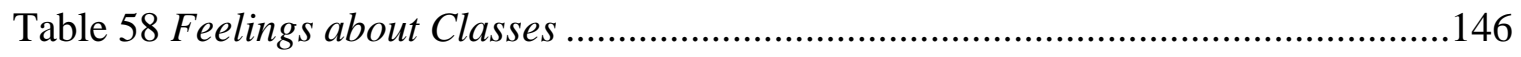

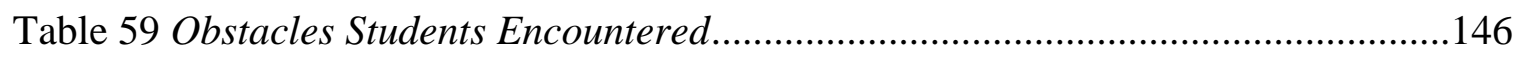

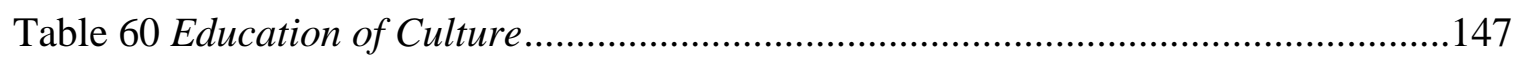

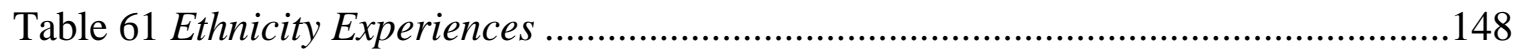

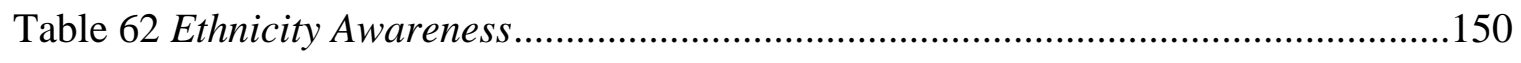

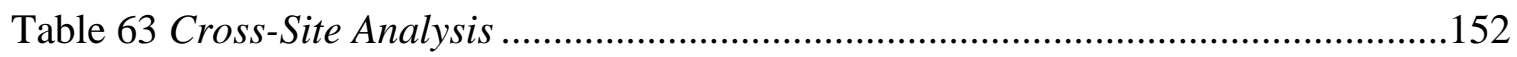




\section{List of Appendices}

Appendix A: Letter to Request Institutional Site Approval...........................................181

Appendix B: Case Study Participant Invitation Letter ...............................................182

Appendix C: Letter to Request Permission to Use MEIM ...........................................183

Appendix D: Letter Template Granting Permission for Use of MEIM ...........................184

Appendix E: Letter to Request Institutional Approval for Pilot Study...........................185

Appendix F: Letter Template from Institution Granting Permission

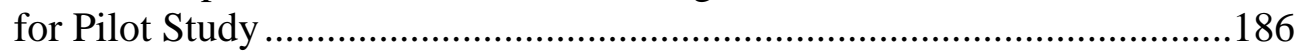

Appendix G: Pilot Participant Invitation Letter........................................................187

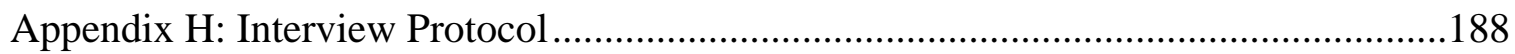

Appendix I: Multigroup Ethnic Identity Measure (MEIM) ........................................190 


\section{List of Figures}

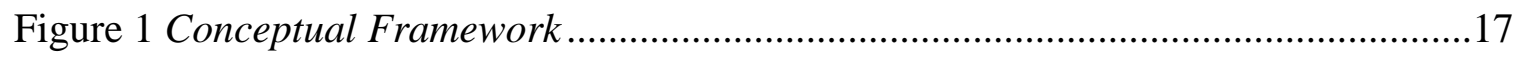

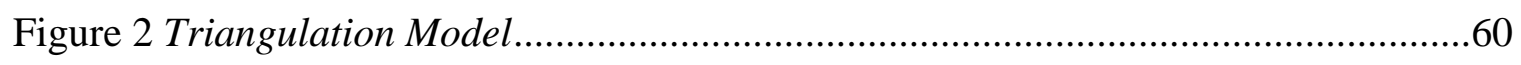




\section{Chapter One: Introduction and Problem Statement}

“No tengo ninguna idea de lo que acabas de decir.” Imagine being in a classroom where you were expected to take notes, pass the subject, and pass state mandated tests. Now, imagine that you did not speak the language of the teacher in the classroom or most of the other students. This is a problem for many of our Hispanic students who are entering classrooms in our public schools. Often, language barriers cause students to be misdiagnosed and placed in classrooms where they do not belong. This problem is compounded after years of being placed in inappropriate classes that fail to meet the students’ needs and do not address their levels of intelligence. Unfortunately, these students have taken standardized tests in English, which is their second language, and, consequently, score lower than if they had been tested in their primary language. Consequently, many of students are placed in remedial classes and are not exposed to classes that will prepare them for college. To make matters worse, most of the parents of these students are Spanish-speaking only and are unaware of the challenges that their children experience because of the language barrier. Furthermore, although many of these parents may want what is best for their children, they often do not know how to advocate for their children's rights. Students are often forced into a track that limits their opportunities to participate in more challenging academic classes which inevitably affects their entry into higher education.

To better understand this problem, educators need to examine the following scenario. Jose and Fernando are brothers who entered a middle school in Allegany County, Maryland. When they entered the school, the guidance counselor looked at their most recent test scores and placed them accordingly. During the time the students were enrolling, a meeting was held to determine the best placement for the boys. Because of their low test scores in reading and math, the guidance department determined that the boys' needs would be best met in the lower section 
where a special education teacher was present. The boys were assigned to collaborative classrooms where both a regular education and a special education teacher worked with students. The group of individuals also determined that these boys qualified as English as a Second Language (ESL) students and would receive services for one hour (two thirty-minute time intervals) a week to learn English. The committee adjourned, and the boys began their education.

In the middle school setting in Allegany County, Maryland, teachers are typically placed on teams representing all subjects. These teams meet daily to discuss students' progress in each of the academic areas. After Jose and Fernando had been in the school for one month, teachers discussed their progress. Upon discussion, their math teacher noted that both boys performed extremely well in their math classes. As the discussion progressed, all teachers reported that the boys made tremendous progress in all of their academic classes. Thus, the teachers went to the guidance counselor to discuss the boys’ placements. According to the guidance counselor, the boys were placed appropriately based on their test scores. They were placed in classes for students who had not passed the state-mandated tests and would receive remedial work in those classes.

Unfortunately, this scenario is all too similar for many Hispanic students. They get placed in classes based on test scores and not their true academic abilities. Consequently, they are not afforded the opportunities to take classes that align with college courses and they are miss valuable information that is distributed in advanced classes. Unfortunately, not only do these students miss out on the education they deserve in the public school setting, but they also are not given the advantages that many of their peers. They simply are not in classes where students are shown the "rules" of college. 


\section{Statement of Problem}

As the above scenario illustrates, school systems in Maryland must address the need for change in the methods used for placing Hispanic students in appropriate classrooms. In order to allow Hispanic students more access to higher education, school systems need to develop programs and services that enable the Hispanic population access to classes that better promote students' transition to higher education and also allow students to gain essential insights and appropriate information that is needed to transition into higher education. Furthermore, school systems must consider that although Hispanic students may be given opportunities at the school setting, many times these students live at home with Spanish-speaking parents who do not understand how to help their children when making decisions to enter college. Moreover, school systems need to understand that students need to have a place where they "fit in" to the school environment.

In September 2008, The Maryland Higher Education Commission’s Minority Achievement Report produced information regarding trends and progress of Hispanic students in institutions of higher education in the state of Maryland (Reid \& Filipp, 2008). Trends in retention, graduation, and transfer rates for Hispanic students continue to remain low in the state of Maryland. According to the Maryland Higher Education Commission, a statewide count from 1994-2004 revealed that Hispanic students who attended community colleges typically were more apt to remain in two-year institutions rather than transfer to four year institutions. In 1994, $43.4 \%$ of students enrolled in community colleges remained; $1.8 \%$ graduated, and $7.0 \%$ transferred to a four year school. In 1998, 39.1\% remained in school, 0.2\% graduated and did not transfer, and 9.2\% transferred to a four-year institution, and in 2004, 45\% remained enrolled, 
1.2\% graduated and did not transfer, and 9.1 transferred to a four year school (Reid \& Filipp, 2008).

The Successful Persister Rate (SPR) is a new measure of student success that Maryland community colleges are using to track students. The SPR measures new students, who have attempted 18 credit hours within the first two years after matriculation at a Maryland Community college and have either graduated or transferred to another college, or those who have not met that criteria, but have completed at least 30 credit hours with a GPA of 2.00 or better and are still enrolled in school. The Successful Persister Rate focused on three cohorts for three years. The rate of students meeting this criterion fluctuated over the three years the cohort was measured. Although the rate of some minority groups achieving "success” was improving, the Hispanic successful persister rate in community colleges in the state of Maryland showed that Hispanic students remained below all students. The SPR for Hispanic students was 66.9 \%in 2000, 64.4 \% in 2001 and $66.7 \%$ in 2002.

The authors of this report discussed a number of ways to improve the diversity of the student population in Maryland community colleges. All colleges reported sponsoring campuswide programs that promote diversity education and make minority students welcome on the campus. Furthermore, all community colleges reported that they made recruitment efforts to include high school visits, on-campus college preview programs, dual enrollment programs and presentations. Moreover, they reported that statewide, an emphasis on reaching younger prospective students is emerging.

Community colleges in Maryland have taken strides to bridge the gap and make transitions into higher education easier for students. For example, Anne Arundel Community College began the Student Achievement and Success Program. This program is designed to 
coordinate the use of college resources to provide individualized academic support services to targeted students who are educationally disadvantaged, low-income, first-generation and/or disabled.

Howard Community College has begun a Step-Up program for all of their students. In this program, faculty, staff, and administrators volunteer to mentor a student for a semester. Although all students are invited to participate in this program, is does allow Hispanic students access to a school mentor on campus. This program was designed to promote the involvement of employees to interact and become involved with students in more meaningful ways that assist with life-coaching skills. The goal of this program was to keep students in contact with the college and see that students are provided services that they may need.

Although services and programs have begun to be implemented into Maryland community colleges, the retention and graduation rate continues to remain below that of their White counterparts. The examination of college participation and degree conferral verifies that Hispanics are an underrepresented group in higher education across the United States. John Hernandez (2002) discussed that although there is an overall growth in the general population, Hispanics continue to trail Whites in terms of college participation rates. In addition, he reported that in 1997, 27.5\% of Hispanic high school graduates between the ages 18 to 21 were enrolled in college, compared to $46.1 \%$ for White high school graduates.

Despite increasing enrollment statistics, the number of degree conferrals is adversely affected by attrition and non-persistence. Because Hispanic students are soon to be the numerical majority in the United States, it is critical that higher education be accountable for understanding, recruiting, retaining, and matriculating Hispanic students (Castellanos \& Jones, 2003). Because of this increase in enrollment, universities must understand the backgrounds and 
cultural differences among this group. Furthermore, a crucial need exists for institutions of higher education to become familiar with the backgrounds and poverty levels that may come from the Hispanic population. Moreover, institutions of higher education must become more involved with secondary education schools and begin to build a smoother transition and create an awareness of attainability of higher education for these students.

Because the levels of education in the Hispanic and other minority societies are tremendously low, many of the families typically do not have the high paying incomes that are predominate in the White culture (Castellanos \& Jones). Consequently, these families may not have access to attain general knowledge that many of the White population do. For example, Hispanic students may not have had the opportunities to travel and to gain broad informational knowledge as their White counterparts. This lack of opportunity obviously places them at a disadvantage before they have even begun to enter an institution of higher education. According to Castellanos and Jones (2003), many students of the Hispanic population have not been exposed to the "rules" of education and the expectations of the professionals who work with them. Although they enter elementary and secondary schools, they often do not attend institutions of higher education since they do not have the background knowledge that the White, middle class does. Research shows that colleges need to provide academic and support services, and peer and professional mentoring at a very early stage in their college careers. Public schools and institutions of higher education need to share responsibility for educating all minority students (Rodriquez, 2002). Programs need to be designed and be implemented in order to bridge the gap between minority students in secondary education and higher education institutions. 
Another challenge that many of these students encounter is the inability to afford higher education. Although scholarships are available for Hispanics and other minority groups, many of these students have not been informed nor do they know where to apply for these scholarships. Thus, a student's “cultural capital” will affect the level and quality of college and education that the student may acquire (McDonough, 1997). This means that because the student may not come from a “middle class” background where certain class status and privilege are provided, the importance of maintaining such status is not a defining issue when choosing an institution of higher education (McDonough, 1997).

Having limited financial means has also been associated with higher attrition rates for Hispanics. Unfortunately, because secondary school guidance counselors are so overwhelmed with assessment, many school systems do not have adequate time to inform students where to attain information that will enable them access to higher education. An examination of economic trends in the middle to late 1980s and throughout the 1990s indicates that college has become less accessible to Hispanics (Orfield \& Ashkinaza, 1991).

Federal Pell grants, once the main source of meeting the costs associated with attending college, increased at a much lower level than the cost of college tuition during that time period. Furthermore, the share of family income required to pay for college costs has increased most for those who occupy the bottom tier of the economic ladder. Low income families have no reserves to draw on and are reluctant to secure loans that will exacerbate family debt (Rendon \& Nora, 1997). Consequently, many students from families in the low-income bracket do not attend postsecondary education.

Tinto (1993) reported that the first year of college is a crucial period for students to get acclimated to the college environment. Upcraft, Gardner, and Barefoot (2005) cited 
overwhelming evidence that student success is largely determined by experiences during the freshman year. Furthermore, a study conducted by Arbona and Nory (1990) that examined the persistence of incoming Hispanic students reported that Hispanic students who had greater educational expectations achieved higher first-year college grades (Hernandez, 2002). Tinto (1993) indicated that an important component of persistence is the willingness of students to work toward the attainment of their goals.

In the literature review of this dissertation, information regarding family and social influences, financial barriers and cultural barriers are discussed. However, although an abundance of information regarding these issues exists, little evidence identified first-hand programs and services that helped Hispanic students decide to attend college and what colleges to attend. Furthermore, more information regarding how students were assisted in their high schools was studied. For example, how students gained more information from their guidance counselors, teachers, peers, or other school-affiliated personnel was studied. Because most of the information was based on different areas in the country and, then, in turn, grouped together, the researcher had difficulty determining exactly what programs and implementations were best suited for certain parts of the country. Feasibility for certain programs in certain parts of the country may not apply to others. For this reason, the researcher focused on students who were attending two-year public institutions in the state of Maryland. The researcher discovered, through qualitative research, what programs and practices provided students the initiative to attend college, how students choose specific colleges, and what programs existed within the current institution to ensure attainment. Although extensive research had been completed with regard to family and social structure within the Hispanic population, the researcher felt that 
answers to these questions were critical to obtain a foundation of where to begin the next step to better serve these students in college.

\section{Purpose of the Study}

Tinto (1993) discusses the processes by which students become integrated into the academic and social systems of colleges or universities through a three-stage process: separation, transition, and incorporation. The first purpose of this study was to examine how individuals influence Hispanic students to attend and remain in college to fulfill their academic goals. The second purpose of this study was to determine what methods, practices, and current programs assisted Hispanic students with their transition into higher education and facilitate their retention in higher education. The researcher expected to gain information to benefit secondary school systems and colleges to determine what programs and services Hispanic students identified helped them best transition into college.

By examining this topic, the researcher can help students and families become aware of programs and services that would enable them to be more successful in attending college. Furthermore, the research enables school systems to work with each other. In addition, the research generates an understanding between the secondary school systems and institutions of higher education that a clientele of students exists that need support in how to "play the game" in order to be successful in higher education.

For this dissertation study, the researcher created the following questions:

\section{Research Questions}

1. What internal influences affect Hispanic students to attend college?

a. How do peers of Hispanic students and parents and other family members of Hispanic students encourage their children to attend college? 
b. What are the expectations of the family once their son or daughter attends college?

2. What external influences and supports do Hispanic students obtain from high schools?

a. What programs helped these students with transition to their higher education?

b. How are Hispanics made aware of opportunities such as grants and financial aid while attending high school?

c. What individuals in the public school encourage Hispanic students to consider college as an option? How do they encourage them?

3. What supports and services did students obtain from the community college?

4. How socially integrated are students in the community college?

5. How integrated are students academically in the community college?

6. What challenges do Hispanic students encounter as new students in higher education?

7. How committed are students to their career goals and the completion of their community college degree?

\section{Significance of the Study}

In order to help Hispanic students successfully transition from secondary education to colleges, students, teachers, and administrators must know what programs and services help this transition. They must understand what their school systems are "missing” that will enable more students to attend college. By conducting a qualitative study on community colleges campuses in the in the state of Maryland, the researcher learned from students what programs, services, school personnel, and other means, helped students make the jump from secondary education to college. 
This qualitative study helps school systems learn what actions they must take in the secondary school setting to help Hispanic students. This research allows school systems to examine what other systems are doing in the state and determine what is working for students. With this examination, school systems may use information to incorporate into their own school settings.

This study also provides opportunities for community colleges to examine what programs and services exist at colleges to determine and possibly adopt programs that are working. The study allows colleges to gain information regarding social clubs and organizations and support services that may focus only on the Hispanic population within the college environment. Moreover, it shows what community colleges are doing in the state of Maryland to help retain students on their campuses.

In chapter one the researcher reviewed the percentages and statistics of Hispanic students who were enrolled in college. She determined that problems existed for Hispanic students with regard to student retention and attrition. She also determined that while the number of Hispanic students who are attending college is growing, the Hispanic population is still behind its White counterparts. In chapter two, the researcher conducted a literature review to determine barriers or obstacles that are causing Hispanic students to continue to fall behind and how Hispanic students determine which colleges they are going to attend. In chapter three, the researcher designed an interview protocol and gained permission from Dr. Jean Phinney to use her Multigroup Ethnic Identity Measure (MEIM) to gain insight on how students perceive themselves with regard to their ethnic identity (Phinney, 1992). The researcher conducted a qualitative study on two community colleges in the state of Maryland to better understand what students perceive as ways to help them attend and stay in college. 


\section{Chapter Two: Review of the Literature}

\section{Introduction}

This literature review examines retention rates among the Hispanic population in higher education and barriers that Hispanic students face in higher education. The researcher will explore attributes with regard to both individuals and families that affect student attrition at higher education institutions.

A steadily increasing discrepancy between the enrollment of Hispanic students and the number of Hispanic students graduating from institutions of higher education exists (Longerbeam, Sedlacek, \& Alatorre, 2004). Moreover, while retention has been studied in general, the unique aspects of Hispanic student retention have not been a particular focus. Consequently, the study of retention of Hispanic students in U.S. colleges and universities has become increasingly important (Longerbeam, Sedlacek, \& Alatorre, 2004). Because Hispanics as a group are diverse in ethnicity, socioeconomic status, language, and national origin, all contribute to this complexity and diversity of students (Longerbeam, Sedlacek, \& Alatorre, 2004).

To explore the multiple obstacles that Hispanic students may encounter when attending and transitioning into institutions of higher education, this literature review is divided into several sections. The first section discusses the struggles and barriers students and their families face when first deciding to attend institutions of higher education directly from high school. This section reveals goals and intentions that students may have when first deciding to attend college and barriers students face with regard to family obstruction and obstacles that students encounter transitioning from secondary education to higher education institutions when leaving the family environment. 
Next, the researcher will explore external influences that affect the ease, or lack thereof, of transitioning between secondary and higher education. The researcher will also focus on integration both academically and socially that affect the retention rates of students.

This researcher will explore Tinto’s (1993) model of academic departure. The researcher will use variables from this model which include students' familial and social supports, academic preparation, and financial knowledge and resources. The literature review will conclude with the discussion of activities and assistance both academically and socially that exists on campuses.

\section{Changing Student Demographics and College Choices}

The American college campus, like society as a whole, is experiencing an expansion of racial and ethnic diversity. Estimates are that by 2050, minorities are projected to account for 47 percent of the population (Aragon, 2000). These demographic trends are also apparent in the enrollment patterns of American colleges and universities. Ethnic minorities accounted for more than half of the 30 percent expansion in students’ enrollment between 1976 and 1994 (Aragon, 2000). Due to their geographic accessibility, open door admissions policies, and reduced costs, community colleges are especially likely to serve a diverse student body. Furthermore, a choice to attend a community college rather than a four-year institution may also be a result of an educational system that prepares students for destinations that are similar to their family backgrounds (Kurlaender, 2006). Consequently, many Hispanic students are enrolling in community colleges. Currently, ethnic minorities comprise approximately 30 percent of student enrollments at American community colleges (Laanan, 2000).

Undergraduate enrollment increased between 1989 and 1995 by half a million to reach 12.2 million students (Horn \& Berger, 2004). However, these students represent much different demographics than have past student populations. While the percentage of Whites decreased to 
$71 \%$ of the campus population, the percentages of Black and Hispanic students increased to each represent 12\% of the total student population between 1985 and 1999 (Horn \& Berger, 2004).

Community colleges provide the opportunity for people with multiple ethnic backgrounds to attend institutions of higher education. Community colleges successfully serve many individuals' educational and career goals. For many students attending community colleges, the subbaclauraeate credential is the primary educational objective and serves as the impetus for opportunity and social mobility (Aragon, 2000). This type of demographic environment is appealing to ethnic minority students who seek to improve their lives through education (Laanan, 2000). Community colleges enroll a substantial percentage of ethnic minorities, women, and nontraditional students. For the majority of individuals, graduating from high school and enrolling immediately in a four-year college or university is considered the traditional route. However, today, attending a community college upon graduating from high school is becoming a popular route, especially among underrepresented groups (Laanan, 2000). Laanan believes that community colleges serve as opportunities for social mobility. Students who are trained in areas offered by community colleges are more likely to secure positions in the world of work that lead to high-skill, high-wage careers.

\section{Transitioning from Secondary to Higher Education}

Tinto (1993) suggests that departure from college is most likely due to the absence of social and intellectual integration into or membership in community life and of the social support integration provides. He further suggests that an “institution's capacity to retain students is directly related to its ability to reach out and make contact with students and integrate them into the social and intellectual fabric of institution life” (Tinto, 1993, p. 204). 
The framework of this study is based on Tinto’s (1993) model of student departure. There are two basic stages in student integration into college. The first stage occurs before students enter college. During the pre-college stage, students ideally develop the academic skills, possess familial and social support, and obtain financial resources necessary to successfully navigate to the college environment. The interaction of familial and social support, academic skills, and financial resources at a student's disposal influence the student's decision to enter college. Once matriculated, the academic and social systems of the college interact and affect a student's ability to be integrated into the institution. The academic success and social integration skills of undergraduates interact to influence their continued goals and help determine if the student persists or departs from the institution.

In 1975, Vincent Tinto developed a theory as to why students depart from college. Tinto explained that the individual characteristics that students possess as they enter college influence their initial commitments to institutions, their goals for graduation, and their departure decisions (Braxton \& Hirschy, 2004). The basic argument of Tinto’s model is that social and academic integration are essential to student retention. Tinto’s 1975 and 1987 models for student departure have provided a workable and testable foundation for analyzing the multiple factors involved with student departure (Rendon, Jalono, \& Nora, 2001).

In 1993, Tinto revised his model incorporating two additional components. First, the influence of external communities was added. Second, student’s financial resources were included as part of the entering characteristics with which students enter college. The rest of this model remained intact and continued to emphasize that some degree of academic and social integration must exist for students to persist (Tinto, 1993). Tinto emphasis, 
in its full form, the model of student institutional departure sees the process of persistence as being marked over time by different stages in the passage of students from past forms of association to new forms of membership in the social and intellectual communities of the college (Tinto, 1993, p. 135).

Tinto further explains that persistence to retention requires that individuals make the transition to college and become involved in both its social and intellectual life. Tinto's model is described as an "interactional system model of individual leaving” (Tinto, 1993, p. 136). The model defines the necessity that both forms of integration, social and intellectual, are essential to student persistence. Students must become integrated into the social and academic communities of the college. The philosophical framework of the dissertation research study is based upon Tinto’s model of student departure (see Figure 1). Within this framework, there are two stages in student integration into college: the first stage of the framework focuses on the integration and transition that students experience when first entering college. The second stage of this framework focuses on the student once he or she has entered college. It discusses colleges’ interactions with regard to the social and academic systems of the college once the student has made the decision to attend the institution. 
Figure 1

\section{Conceptual Framework}

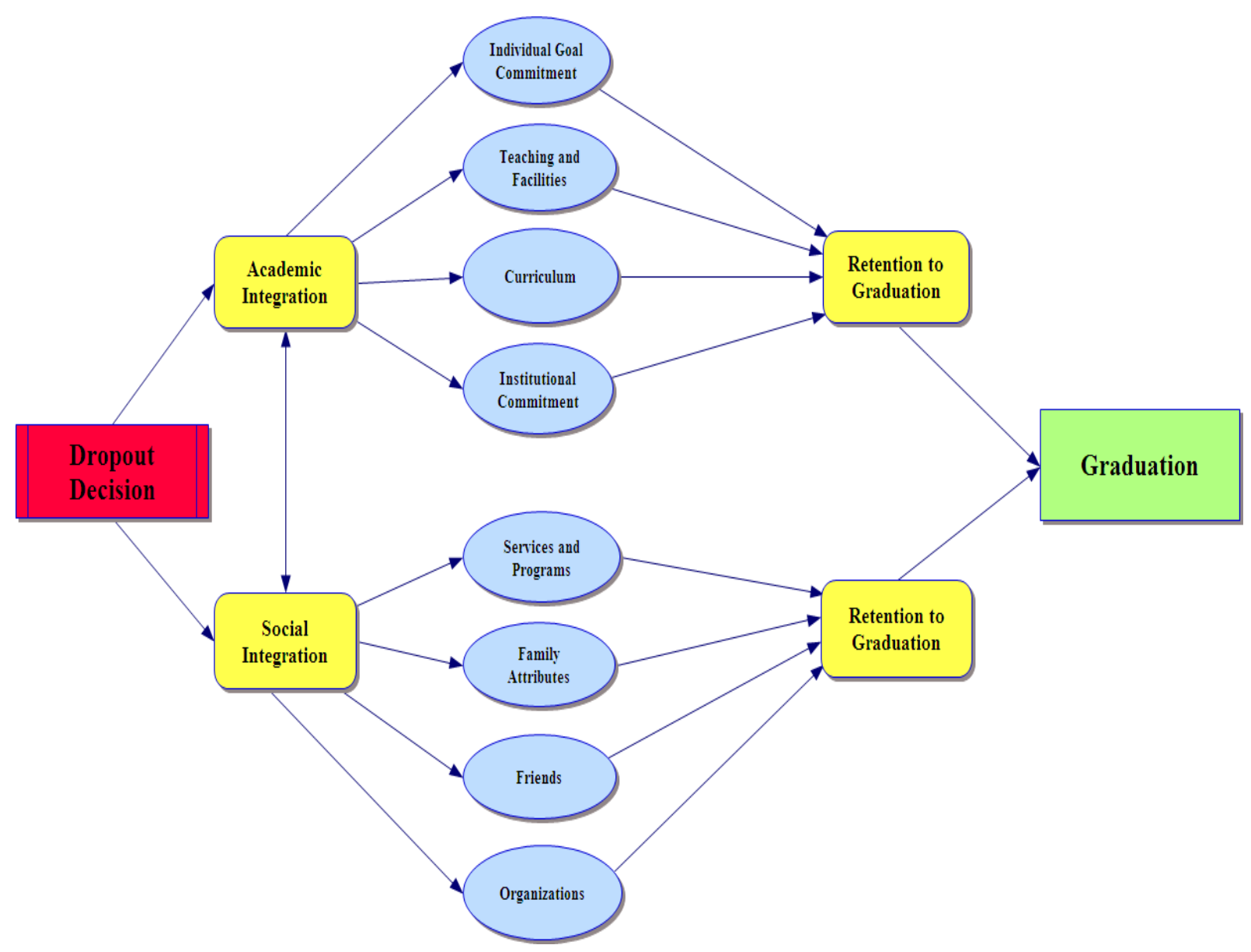

\section{Achieving Goals and Intentions through Community Colleges}

Students encounter multiple choices when deciding to attend an institution of higher

education to pursue education beyond high school. Choices students make are a combination of the relationships of the individual, family, cultural capital, and the structure of the organization (McDonough, 1997). Students must consider the career paths they are choosing and skillfully choose an institution that meets those needs. Furthermore, students must know of the cost of the institution.

For many students, colleges and universities that are out of state or far away from home tend to cost more. Community colleges provide opportunities for people in all stages of life to 
attend college. Community colleges allow people to advance their education and careers, regardless of their educational backgrounds (Laanan, 2000). This demographic environment is appealing to ethnic minority students who seek to improve their lives through education. Community colleges are institutions that are ideal places for individuals to explore their educational and career goals. The option of attending a community college can be viewed as opening college opportunities for many students (Laanan, 2000). Due to the lack of funding and opportunities for Hispanic students, many are most likely to choose institutions with low tuition costs and classes that can be scheduled around work and family commitments. Results from an analysis reported by Kurlaender (2006) show that Hispanic students generally are much more likely to attend a community college than are African American or White students from similar socioeconomic backgrounds.

\section{Family}

Hispanic students report that they rely on their friends, peers, and faculty members in the transition to college (Hurtado, Carter, \& Spuler, 1996). However, since Hispanic culture relies on familial support systems, students also tended to identify the support of family members during college essential in transitioning to college (Castellanos \& Jones, 2003). Unfortunately, since the majority of Hispanic students come from families where they are first-generation college students, the necessary support needed to cope with challenges they encounter may not exist because of the lack of college knowledge (Castellanos \& Jones, 2003). Furthermore, Nora and Lang (1999) found that skills and attitudes developed prior to enrollment in higher education have an impact on the student's decision to remain in college. Contributing factors that may have an impact on Hispanic student's skills and attitudes are as follows: 
1. Hispanics under age 5 are less likely to be enrolled in early childhood education programs than other groups.

2. The enrollment of Hispanic children in preschool increased with increases in parent educational attainment.

3. Fewer Hispanics age 25 or older complete high school than do African Americans and Whites.

4. Enrollment also increases along with increases in family income. But here, too, Hispanics with a median family income of $\$ 28,000$ lag behind the $\$ 39,000$ median income of the population at large.

5. While 36 percent of Hispanic children live in poverty, only 26 percent attend Head Start programs, which are designed to remedy the effect of poverty on education achievement.

6. Although children three to five years old may start school better prepared to learn if they are read to, only 65 percent of Hispanic children are read to compared to 75 percent of African Americans and 90 percent of Whites.

7. $70 \%$ of preschool teachers assert that they are not fully prepared to meet the needs of students with limited English proficiency or from diverse cultural backgrounds. Such lack of preparation can seriously impede the quality of Hispanic children's preschool education. These issues among others create serious barriers for Hispanic students to experience success in institutions of higher education (Hispanics in Education, 2001). 
"In the social organization of Hispanics, family is considered the single most important institution. It is through the family and its activities that many Hispanics relate to significant others in their lives and learn to interact with greater society” (Castellanos \& Jones, 2003, p. 7).

Arellano and Padilla (1996) report an examination of factors contributing to the academic success of Hispanic students proved there was a powerful effect of parental influence on students’ academic success. According to Arellano and Padilla (1996) each respondent referred to the critical importance of parent support and encouragement. Unfortunately, this tendency to remain loyal to the family may cause students to withdraw from school.

Tinto (1993) reports that racial or ethnic minority students who attend commuter institutions are typically first-generation collegians and are from low socioeconomic status backgrounds. Tinto further reports that due to the backgrounds of the parents of these students, the parents' educational experiences, the students' secondary school experiences, and their peers' educational expectations, many students enter commuter institutions lacking a strong commitment to graduate. Furthermore, family responsibilities and working off-campus may exert a "pull away" effect on students' social and academic integration and will then consequently affect their decisions to remain enrolled (Nora \& Wedham, 1991). Nora, Cabrera, Hagedorn, and Pascarella (1996) report that minority students who attend commuter institutions often have jobs, live away from campus, and have demanding family responsibilities. Moreover, Hispanic and African American women who reported taking care of a family member were 83 percent more likely to leave college than their counterparts without such responsibility (Nora \& Cabrera, 1996). Although some parents will be supportive, many will not be extremely active in their daughters’ college searches or may even limit their daughters' searches because they may want to keep the cost down or keep them closer to home (McDonough, 1997). Some parents 
have even encouraged their daughters to stay close to home because the people are "more like us” (McDonough, 1997). Consequently, departure decisions may be influenced by how students negotiate these conflicts within their families and significant others.

Tinto (1993) reports that, the impact of work and family obligations may not, however, be the same for all students. Studies of retention among married students, for example, suggest that family responsibilities may sometimes hinder persistence but "may do so more for females than for males” (Tinto, 1993, p. 64). Tinto further reports that, "though being married is generally associated with higher rates of persistence among men, it is often related to lower rates of completion among women” (Tinto, 1993, p. 65). This is even more evident in Hispanic students, where women who leave college “typically report extensive family duties as a prime cause of their inability to complete a college degree program” (Tinto, 1993, p. 65).

Research conducted by Nora and Cabrera (1996) focused on three factors that heavily weighed on a student's decision to remain in college. Those factors included encouragement and support by parents, academic performance, and the student's own sense of developing academically while in college. Nora and Cabrera (1996) indicated that while perceptions of discrimination and prejudice on campus negatively affected the adjustment to college and several college related outcomes, students' success was due to the students’ perceptions that their families were supportive and provided encouragement while they were enrolled in college. Furthermore, the authors found that successful adjustment to college may have included severing previous ties with family, friends, and past communities (Nora \& Cabrera, 1996). Such links to significant others were instrumental for the successful transition from high school to college among Hispanics. Furthermore, Nora and Cabrera report that parental encouragement and support were found to serve as a positive influence on a student's integration into college, as well 
as on academic and intellectual development, academic performance and commitments, and decisions to remain enrolled in college (Nora \& Cabrera, 1996). This single factor has been found to significantly impact on the determination of minority students to persist. Furthermore, it is believed that, "the influence of family and community in the persistence process is to the interrelations between Tinto’s (1993) transition phases and different sources and forms of encouragement and support from significant others” (Castallanos \& Jones, 2003, p. 60).

As previously stated, the major components of the framework of this study are guided by Tinto’s model of student retention with regard to academic and social integration Hispanic students experience when entering college. According to Tinto, students must experience both academic and social integration to return to college. Tinto reports that, the first stage of the college career, separation requires individuals to disassociate themselves, in varying degrees, from membership in the communities of the past, most typically those associated with the family, local high school, and local areas of residents. (Tinto, 1993, p. 95)

According to Tinto, students' communities often “differ from college not only in composition but also in values, norms, and behavioral and intellectual styles that characterize their everyday life (Tinto, 1993, p. 95). Thus, a transformation of the former behaviors to the new adopted behaviors must occur (Tinto, 1993). Consequently, according to Tinto, students may have to change behaviors, alter relationships, and focus on different values from which they have been accustomed. Tinto (1993) suggests that this change in direction will help assist with student retention. However, this is difficult when most, if not all, of Hispanic students attending two-year institutions come form the surrounding community where the college is situated and live at home (Nora, 1990). 
Results from another study (Laanan, 2000) that further examined Hispanic students concluded that the extent of family influence on occupational career choices found that when compared to their non-Hispanic American counterparts, Hispanic students showed that they were much more influenced by their families and tended to choose colleges near home so that they could still be involved with the family environment. A group of more than two thousand eighthgrade, twelfth-grade, and community college students from 11 Texas school districts and three community colleges, as well as 500 parents, were surveyed. Hispanics students perceived their parents to have a greater influence on occupational and educational decisions. Furthermore, financing their college educations was a major concern among the Hispanic population. Moreover, non-White students indicated that they chose community colleges because of low tuition costs, in addition to having the desire to live near home, job-placement rates, the college's reputation as a good academic institution, and the thought that a community college is an extension of high school. Furthermore, the students in this study noted that attending a community college was their first choice because it enabled them to get a better job and make more money (Laanan, 2000).

\section{External Influences and Supports}

Although many variables exist when Hispanic students are making decisions concerning higher education, external influences and supports are crucial components to help students make appropriate choices. Teachers in both upper and lower tracks often play a tremendous role in helping students prepare for and make decisions pertaining to college. Teachers, ironically, actually play a larger role in helping students make choices and decisions regarding higher education than school guidance counselors (Kirst \& Venezia, 2004). Therefore, is it critical that teachers are aware of key issues regarding admission policies, placement standards, and financial 
requirements for students who lack connections to broad-access post-secondary and placement information.

Hispanics are the largest ethnic minority in the United States, yet Hispanic students are the least likely of all the major ethnic groups to graduate from high school, go on to college, and earn a degree (Gandara, 2004). In 2000, only 10 percent of Hispanics nationwide had earned college degrees, compared with 18 percent of African Americans and 34 percent of European Americans (National Center for Education Statistics, 2009). According to the National Assessment of Educational Progress, 41 percent of white students are proficient in reading by $4^{\text {th }}$ grade, compared with only 15 percent of Hispanic students. And, by $12^{\text {th }}$ grade, a point by which significant number of lower performing students have already dropped out of school, only about one fourth (26 percent) of Hispanics have achieved proficiency in reading, compared with almost one-half) 47 percent of white students (National Center for Education Statistics, 2009).

Perceptions that students who get counselor, teacher, or parental assistance on financial aid are more successful in higher education may exist, however, due to the already-existing gap of abilities, Hispanic students who get help on their college entrance or financial-aid applications, or who receive such aid, are not significantly more likely to graduate from college than those who get no help (Swail, Cabrera, Lee, \& Williams, 2005). Furthermore, although financial concerns are important, it is the types of funding in certain combinations along with the costs - not just the question of whether Hispanic students do or do not receive aid affects whether they graduate from college. Moreover, courses Hispanic students take in high school are more important to their success in college than any help they may receive with college applications (Swail, Cabrera, Lee, \& Williams, 2005). In addition, Hispanic students who either aspire to attend college as early as eighth grade, who enroll in college right after high school, who stay 
enrolled continuously, or who have parents who expect them to get an advanced degree, among other factors, are the ones who are more likely to graduate from college than their counterparts who do not meet those criteria (Swail, Cabrera, Lee, \& Williams, 2005). Components that help retention and college graduation are as follows:

1. Give Hispanic students enough academic support services and safety nets,

2. Track their academic progress, especially during freshman year,

3. Stress financial-aid programs that allow students to stay enrolled continuously, and

4. Link the financial-aid office to the academic and social-services branches of the university to provide coordinated support.

By tracking this information, numbers of retention rates among Hispanic students will increase and the success rate among this population will rise (Swail, Cabrera, Lee, \& Williams, 2005).

Previous academic achievement is a significant factor in the college choice process. Higher achieving students (as measured by their eighth grade math achievement scores) are on average, more likely to start their postsecondary schooling at four-year institutions than community colleges, even when race, socioeconomic status, and degree intention have been held constant (Castellanos \& Jones, 2003). Hispanic students’ performance on standardized achievement test in the NELS data set is, on average, higher than African Americans' but lower than white students’ performance. However, Hispanics’ choice to attend community colleges over four-year schools extends beyond academic achievement (Kurlaender, 2006). Consequently, although eighth-grade math scores positively affect White and African American students' probability of attending a four-year institution, they do not change the likelihood that a Hispanic student will begin postsecondary education at a community college. For Hispanic 
students, attending a community college is an inevitable choice for postsecondary education (Kuelaender,2006).

Although the basic right to equal school access eventually became a reality, equal access has not led to equal achievement (Barton, 2004). Although local communities, state policymakers, and the federal government have kept equal achievement on their agendas, as expressed in such efforts as the Elementary and Secondary Education Act of 1965, equal achievement has remained just around the corner (Barton, 2004). Barton (2004) conducted a project that examined how well he could determine why the school achievement gap persists. Barton first identified the life experiences and conditions that research showed were associated with school achievement, and secondly, he looked for statistics that indicated whether children's experience with each factor differed on the basis of race/ethnicity and income. The information was divided into 12 factors. Data were available for each of the 12 factors and evidence showed that a gap for 11 of the 12 factors existed for minority students. The data concluded that achievement gaps by race/ethnicity and income mirror inequalities in those aspects of schooling, early life and home circumstances that research has linked to school achievement (Barton, 2004).

Data from the U.S. Education Department's National Education Longitudinal Study, a long-term study of the academic progress of a random sample of 26,000 students who were first surveyed in 1988, when they were in the eighth grade, and follow-up studies which were completed in 1990, 1992, 1994, and 2000, concluded the following:

1. Eighth graders who plan to attend college are 48 percent more likely to complete college than their counterparts who have no such plans.

2. Those who plan to get a bachelors' degree are 53 percent more likely than their counterparts to graduate. 
3. Students who maintain continuous college enrollment are 60 percent more likely to graduate.

4. Students who have a grade-point average between 2.50 and 3.29 are 47 percent more likely to graduate, and those with a GPA between 3.2 and 4.0 are 62 percent more likely.

5. Students with parents who expect them to get an advanced degree are 46 percent more likely to graduate than their peers without such expectation.

6. Students with parents who expect them to get bachelor's degrees are not significantly more likely to graduate than peers whose parents have no such expectations.

7. Hispanic students are 20 percent more likely to get a college degree than their male counterparts.

8. Delaying college enrollment after finishing high school reduces graduation rates among students by 20 percent. (Rampey, Dion, \& Donahue, 2009)

Not only are Hispanic students obtaining postsecondary education degrees at a lower rate than their White, non-Hispanic counterparts, they are also graduating from high school with a lower level of academic skills. African American and Hispanic 12th graders across the United States read and do math at the same level as white 8th graders on average (Kirst \& Venezia, 2004). Consequently, many low-income and minority students take remedial courses in college, which lowers their chances for completing either a two-year or four-year degree or a vocational certificate. Moreover, broad-access institutions, community colleges, or four-year institutions that admit just about every student who applies represent about 85 percent of all postsecondary school and educate approximately 80 percent of the nation's first-year college students. Kirst 
and Venezia (2004) argue that instead of focusing on the 20 percent of students who attend the most selective four-year institutions with the wealthiest and best-prepared student models, media and public attention should focus on program completion rates for students from low socioeconomic brackets attending broad-access institutions.

The Stanford University Bridge Project, a six-year national study, analyzed high school exit level policies and college entrance policies to discover whether a discrepancy exists between the skills that each education system requires. The Bridge Project researchers analyzed state and institutional policies in six states. The data from the Bridge Project showed that high school students in accelerated curricular tracks receive clearer signals about college preparation than do their peers in other tracks. (Kirst \& Venezia, 2004). Postsecondary education outreach efforts by high school and college counseling staff often fail to reach students in middle and lower-level high school courses (Venezia, Kirst, \& Antonio, 2003).

Because student impressions of college are typically shaped by multiple sources, it is imperative that students are provided opportunities from external sources that guide them in the right direction of higher education. Students may receive brochures, magazines, and advertisements for colleges. School guidance counselors, teachers, other students, college fairs, high school visitations, and high school newspapers are just a few of the more obvious sources of information students may experience (Tinto, 1993). Tinto (1993) suggests that although these may be some of the more popular means of communication for students entering college, they may not be the most accurate. For example, many guidance counselors may have outdated or mistaken information and views as to the character of the institution. Moreover, the information provided is not always relevant to the issues of individual congruency and integration into the 
life of the institution (Tinto, 1993). Consequently, some students may not have a full picture of the college or university they plan to attend.

Hispanic families often lack the social capital that is so essential for students to gain a foothold in society (Gandara, 2004, p. 56). Middle-class, predominantly Caucasian, parents advocate on behalf of their children and locate the resources in public schools to enhance their children's successes. Furthermore, these parents know how bureaucracies work, and they have easy access to people in key decision-making posts (Gandara, 2004, p. 56). Kirst (2004) reports that many economically disadvantaged parents lack experience concerning college preparation. They are economically disadvantaged and tend to have occupations such as service workers, craftsmen, operators, farm laborers, and non-farm laborers. On the other hand, they are underrepresented in more prestigious, better-paying occupations including professional and technical workers, managers and administrators, and farmers and farm managers (Castellanos \& Jones, 2003, p. 50). Furthermore, lower income parents cannot afford to send their children to preschool, but they know that their children should be getting something, so they send them to kindergarten early to reap the advantages that they believe it offers (Castellanos \& Jones, 2003). Teachers are, therefore, confronted with 6 year old White children in the same classroom as four year old minority students. As the younger children start school, the deck is already stacked against them (Hale, 2004).

Tinto (1993) reports that although it has been questioned whether financial assistance is not as important to student retention as is commonly thought, short term fluctuations in finances can and do cause a number of students to withdraw from college. Consequently, Tinto (1993) reports that financial-aid programs can help prevent departure by enabling students to overcome temporary financial difficulties. Studies have validated that the importance of financial aid 
creates an equal playing field among recipients and non-recipients. Cabrera, Nora, and Castaneda (1993) revealed an intangible factor associated with financial aid. In their 1993 study, they distinguished between actual awarding of financial aid and attitudes associated with having received financial aid. In those studies, both components were found to directly and indirectly influence the decisions of Hispanic students to remain in college.

It is assumed that the intangible component is not only a reflection of stress reduction that comes from being able to pay for college-related expenses, but that it may also represent a student's commitment to his or her respective institution, centering around the notion that the institution provided the financial means to remain in college. (Castellanos \& Jones, 2003, p. 58)

Tinto (1993) suggests that evidence exists that implies that finances and financial aid may be more important to disadvantaged students from traditionally underrepresented groups than it is for White students. A study conducted by Nora (1993) that focused on financial aid and retention among Chicano community college students argues that the interplay between financial aid and financial resources is essential to the students’ persistence. Furthermore, these variables tended to play a more significant role in the retention rates for these students than their high school grades and their accumulative grade-point averages at the two-year institution.

Janet Murguia, President and CEO of The National Council of La Raza (NCLR), stated that numerous polls show that Hispanics value education, but the price of attending our nation’s postsecondary institutions is among several obstacles Hispanic children face in achieving their dream of attending college and fully contributing to society. The reduction of loan interest rates is an important first step in opening the doors to higher education for millions of Hispanics (Pernick, 2007). Financial aid creates an equal field among recipients and non-recipients. The 
College Student Relief Act of 2007, passed by the U.S. House of Representatives, reduced college loan interest rates. Since Hispanics compose $18 \%$ of the total college-age population, but constitute only a small proportion of undergraduate students in U.S. postsecondary institutions; only $10.4 \%$ of all 2002 undergraduate students for Hispanic, for many low-income Hispanics students, the most significant barrier to attending college is cost (Pernick, 2007).

\section{Social Integration: Programs, Services, and Retention Rates}

“Understanding perceptions of the environmental context and subsequent academic comfort of racial and ethnic minorities in higher education is particularly important when studying persistence” (Castellanos \& Jones, 2003, p. 7). Pascarella and Terenzini (2005) suggest that certain college environmental conditions exert independent effects on educational attainment. They suggest that programs and activities such as a cohesive peer environment, frequent participation in college-sponsored activities and a perception that the institution is concerned about students as individual must exist. Although Hispanic students are beginning to graduate from college and enroll in college, drop-out rates remain high. Many times, these students enter a college campus and feel intimidated because of the high populated White campus environment as well as the predominately White faculty. These campuses may have little understanding of minority cultures, racism, and fiercely competitive learning environments, as well as a Euro-centered curriculum (Castellanos \& Jones, 2003). Minority students may feel culturally or racially isolated on campus. "The lack of minority role models and mentors, the lack of minority issues or materials in the curriculum, and the lack of noticeable minority support programs has led to adverse conditions that must be faced by Hispanic undergraduate students” (Castellanos \& Jones, 2003, p. 55). Consequently, Hispanic students are less likely to successfully transition from high school to college or to become involved in institutional life on 
campus, which itself leads to attrition (Castellanos \& Jones, 2003). Furthermore, for minority students whose cultures of origin do not resemble the dominant culture of the social communities of their college or university, a cultural enclave or affinity group of students who share the same culture must be found. Braxton, Hirschy, and McClendon (2004) report that if this environment does not exist, such minority students will not perceive that potential for community exists for them. Consequently, minority students in residential colleges and universities with small numbers of minority students enrolled may perceive that the potential for community does not exist at their institution because few, if any, cultural enclaves of affinity subgroups exist. Consequently, students may choose to leave the institution because they do not feel that they "fit” into the campus culture. Tinto (1997) addresses that the academic and social climat in higher education institutions definitely influence academic outcomes for Mexican American and other Hispanic students. Tinto emphasizes the importance of knowing the characters of an institution’s climate with regard to how Hispanic students experience it.

Braxton, Hirschy, and McClendon (2004) who have re-visited and revised Tinto’s theory of student departure, describe six influences on social integration that was derived from the body of literature of theory and research on college student departure. They discuss that communal potential, which refers to the anticipation of membership in a particular community of a college or university, must exist in order for attainment to occur. This means that an anticipation of membership stems from the perception that a subgroup of students exists within the college community with which the student shares similar values, beliefs, and goals (Braxton, Hirschy, \& McClendon, 2004). Furthermore, Nora (1993) concluded within four factors that contribute to persistence and subsequently graduate social integration and experiences were crucial to the retention. Included in the social integration and experiences factor is that students must have 
formal and informal academic interactions with faculty, involvement in learning communities, in-class experiences, outside of class experiences, collaborative learning, social experiences, peer group interaction, involvement in organizations, campus climates, perception of prejudices discrimination, tolerance versus acceptance, validating experiences, encouragements and support from faculty and staff, as well as counseling and advising staff. Tinto (1997) notes that institutions that promote improving the social climate and make the social climate more congruent with the lives of Hispanic students and have provided special programs, services, and physical facilities such as multicultural centers, and tutoring, and mentoring centers, help students retain the sense of cultural identity, and, therefore, help Hispanic students transition from what might be a discomforting experience to one that hosts a sense of belonging.

Castellanos and Jones (2003) discuss Raymond Herrera who has worked extensively in the area of Multicultural Student Services. He indicated that one of the factors that kept him in the system was the supportive people who lived and cared for him and wanted him to succeed. Furthermore, Herrera reports that,

one thing that I did not expect to happen to me has a result of attending a predominantly White university is that I've learned more about Chicanismo and indigenous ways than when I lived in the very diverse San Francisco Bay Area. (Castellanos \& Jones, 2003, p. 118)

Herrera further reports that for most students, college is a time for discovery; however, for himself, the isolation from a Chicano community, from family, and from everything other than the culture of a rural White university and farming community, left him wanting for things that he had previously taken for granted. Although traditions, music and foods became important to him, he intensively missed the cultural ways of his home community. Herrera stated that he 
no longer was able to "get lost” and be “inconspicuous" in a large crowd. Having a yearning for his missed culture, Herrera assisted in the organizing of CAMARADAS, a Chicano/Hispanic graduate student association. Herrera reports that after other Hispanic graduate students spoke with him, these themes resonated for all. Hispanic students felt they had a need for a social support network, a need for mentoring (for themselves and undergraduates), and a need for graduate students to be proactive on behalf of the Hispanic community on campus and around the state (Castellanos \& Jones, 2003).

Longerbeam, Sedlacek, and Alatorre (2004) emphasize that acculturation stress is experienced in differing ways. They stress that coping mechanisms for addressing students’ stress can be varied and may include incorporating the Hispanic community into the campus community as a means of achieving success. They also emphasize the connection and continuity that exists between the Hispanic culture as a response to being a minority on a predominately White campus (Longerbeam, Sedlacek, \& Alatorre, 2004). An overall climate that is welcoming and provides opportunities to incorporate Hispanic culture is an important institution contribution to lowering Hispanic stress. Hurtado, Carter, and Spuler (1996) found that minority status stressors were higher than those who simply had adjustment and transition issues. They suggested that mentoring Hispanic students is extremely important for success in college.

O’Meara and Braskamp (2005) discuss that a widening gulf between students and faculty is occurring. Faculty spend less time than in the past advising and counseling students. Furthermore, they report that the out-of class contact, which is considered a significant role in the retention and persistence of student attrition, does not exist as it did in the past. O’Meara and Braskamp report, 
over the last decade faulty productivity and particularly the standards for publication productivity have been moving upward, while the amount of time faculty spend with students outside of class varies. Furthermore, they report with early retirement programs and increased use of part-time and non-tenure track faculty, fewer tenured faculty are on campus, thus creating fewer tenured faculty to participate in shared governance and coordinate academic programs. As a result, the majority of graduate programs still do not prepare future faculty for, nor do the majority of reward systems necessarily prioritize, faculty engagement with students. (O’Meara \& Braskamp, 2005, p. 230)

Tinto discusses “competent membership in college communities is at least partially determined by the formal demand of the academic system of the college and prevailing intellectual and/or academic culture of the institution” (Tinto, 1993, p. 121). He argues, “culture helps define for the formal structure what is competent membership and what is not” (Tinto, 1993, p. 121). He explains that in order for some form of integration, some type of intellectual membership in at least one college community is a minimum condition for continued persistence. Tinto (1993) stresses that we must consider the impact of integration which occurs in both the formal and informal setting. He discusses integration in the formal academic setting may lead to similar integration in the informal academic setting of the institution. He suggests that contact with the faculty in informal settings outside the classes is a critical component in student persistence generally and students’ intellectual development in particular (Tinto, 1993). Unfortunately, social integration of students can prove to be challenging, especially for students who are attending community colleges. Many community college students struggle with having the confidence of feeling comfortable and knowing their way around campus (Tinto \& Love, 1995). Moreover, community colleges have more limited opportunities to engage students. 
Most student-faculty interaction occurs in the classroom and many students do not participate in college sponsored extracurricular activities (Center for Community College Student Engagement, 2009). The 2009 Community College Survey of Student Engagement (2009) found $60 \%$ of the community college students were part-time students and $57 \%$ of these students work more than 20 hours per week (Center for Community College Student Engagement, 2009). These two characteristics also may make it difficult for students to participate in these types of extra-curricular activities.

Jean Phinney, professor of Psychology, California State University, Los Angeles, who developed the Ethnic Identity Model, discusses that, “ethnic identity develops from the shared culture, religion, geography, and language of individuals who are often connected by strong and loyalty and kinship” (Phinney, 1992, p. 2). In stage two of Phinney’s model, she discusses that ethnic identity development becomes increasingly more aware to the individual because issues may be stimulated by an experience that causes an exploration or a new awareness that causes an individual to examine the significance of her or his ethnic background (Phinney, 1992). This realization into one's own identity may help provide insight and gain awareness to help the individual feel more associated with a particular culture or group. Consequently, making decisions to remain in college may occur due to the feeling of acceptance and awareness into one's culture.

\section{Academic Integration}

Although the number of students enrolling in American colleges is steadily increasing, and the level of confidence entering freshman is at an all-time high, the proportion of students who actually graduate from college is declining, especially among minority students (Pascarella \& Terenzini, 1991). Statistics regarding students’ attrition are startling. One-half of first-year 
students at community colleges do not continue for a second year (Kirst \& Venezia, 2004). The first year of college is the most critical year in the student's college career (Tinto, 1993). The first quarter or semester is typically the stage which typically calls for individuals to separate themselves from past associations and patterns of educational participation, and to make the social and academic transition to a new and more challenging life (Tinto, 1993). Student's persistence in college depends in part upon their integration into the academic environment of the institutions.

Contact/community programs are, as their name suggests, designed to provide new students with contact with other member of the institution and with the carious communities that make up its daily life. Their long-term goal is the incorporation of individual into the academic and social communities of the institutions. These programs go beyond the mere formalities of college life and involve students, faculty, and staff in a variety of formal and informal interactions over a range of topics pertinent to the needs and interests of new students...Contact among other students may be particularly important not only because it helps cement personal affiliation, which ties the new student into the fabric of student culture, but also because it enables the newcomer to acquire useful information as to the informal character in institutional life. (Tinto, 1993, p.165)

Tinto discusses “competent membership in college communities is at least partially determined by the formal demand of the academic system of the college and prevailing intellectual and/or academic culture of the institution” (Tinto, 1993, p. 121). Tinto argues that, “culture helps define for the formal structure what is competent membership and what is not” (Tinto, 1993, p. 121). He explains that in order for some form of integration, some type of 
intellectual membership in at least one college community is a minimum condition for continued persistence. Thus, a social support network, a need for mentoring, and a need for graduate students to be proactive on behalf of the Hispanic community is needed on campuses (Castellanos \& Jones, 2003).

Tinto (1993) stresses that we must consider the impact of integration which occurs in both the formal and informal setting. Tinto (1993) discusses that form of integration in the formal academic setting may lead to similar integration in the informal academic setting of the institution. He suggests that contact with the faculty in informal settings outside the classes are a critical component in student persistence generally and students intellectual development in particular (Tinto, 1993).

\section{Commitment Toward Attaining Career Goals}

Retention, the ability to remain in school and matriculate toward degree completion, is yet another concern when transitioning into higher education. This "revolving door" cycle where Hispanic students enter college, drop out, and are replaced by new Hispanic students occurs in most institutions (Haro, Rodriguez, \& Gonzalez, 1994). Consequently, an illusion of a stable set of students exists because the number of Hispanic students enrolled remains the same. Factors that must be considered are cultural and background variables, socioeconomic status, academic and acculturative stress, family support, campus climate. Furthermore, cultural congruity and faculty mentorship are essential elements that must be present in order for attainment to occur (Gloria, Riechmann, \& Rush, 2000).

Numerous cultural and personal indicators have been key factors that contribute to the achievement and retention of Hispanic students in higher education. Students who have limited English skills, come from single parent homes, have irregular attendance patterns, and have 
received a poor background in quality education all play a significant role in the retention of Hispanic students once they transition into higher education (Rendon \& Hope, 1996).

Furthermore, lack of resources in students' educational backgrounds, such as out-dated books, limited access to technology, and ill-prepared teachers also hinder the success that these students may have in higher education.

Hernandez (2000) suggests that the focus should not only be on failure rates, but on understanding why students who have overcome obstacles and have remained in school and achieved success in college. Hernandez found that “validating” students' desire to succeed and encouraging their optimistic outlook is a central theme for student retention (p. 581). Furthermore, Hernandez (2000) emphasizes that families of Hispanic students are effective tools in retention if they are familiar with the college environment and are provided with the opportunities to develop relationships with the college faculty and administrators. Moreover, students who are provided opportunities to work with the faculty, administrators, and curricular activities allowed Hispanic students to develop a sense of community and support on the college campus.

Tinto (1993) discusses that individual commitment takes two major forms, goal and institutional. Goal commitment is the student's decision to obtain personal educational and occupational goals, and the student's willingness to work towards attaining those goals. Institutional commitment is the student's commitment to the institution in which he or she is enrolled, and it shows the degree to which the student is willing to work to obtain his or her goal. Obviously, the greater the student's commitment, the greater the chance of institutional persistence and student attainment (Malette \& Cabrera, 1991). 


\section{Summary}

In summary, although an increasing number of Hispanic students deciding to pursue education after high school is increasing, the overall retention rates are not improving. Through examining research and literature, the opinion of the researcher is that Hispanic students continue to experience barriers with regard to finances, family concerns, social interference and a lack of informative programs and services available to assist students. Regardless of how secondary schools and community colleges determine to help facilitate the process of providing information to students, the opinion of the researcher is that these institutions must first consider how to approach the family and social settings of this culture. Furthermore, this researcher believes that assistance from secondary schools is critical in creating an awareness of programs and opportunities that exist to help the transition from secondary school to higher education. Moreover, these schools must provide programs that help influence students and ease the burden of the formalities that one encounters when entering higher education. Although research has been conducted that shows some programs and support services exist, it is also clear to this researcher that school personnel are not adequately trained to handle students with these needs and overall a "lacking” of consistency exists among schools. Guidelines and training seminars should be in place for teachers, guidance counselors, and school personnel to help assist students who have interests in attending institutions of higher education.

Finally, although a tremendous amount of literature exists that discusses barriers that students may face when entering college, very little research exists on how to help college and school personnel, administrators, and parents to assist students who have language barriers which prevent them from applying to colleges as most White students. Little research exists that teaches school personnel how to work with students to complete forms such as the Free 
Application for Federal Student Aid (FAFSA) and applications for admittance and scholarships.

Consequently, many of these students are overlooked and passed by when it comes to completing the necessary paperwork that will enable them access to higher education. Hopefully through research and interviews, this researcher will gain first-hand insight on what students’ feel have been the most influential causes to help them persist in higher education. 


\section{Key Terms and Concepts}

Academic Integration: How students are integrated into the academic aspect of the community college.

External Influences: Influences that students may have had from friends, guidance counselors, school personnel, and any other persons excluding family members.

Internal Influences: Influences that students may have had from family members to attend college.

Retention: The ability to remain in school and matriculate toward degree.

Social Integration: How students are integrated into the social aspect of the community college. Success: Full-time students who have completed at least 12 credit hours or students who are part time who have completed at least 12 credit hours and have attended two consecutive semesters. Successful Persister Rate (SPR): A measure of student success that Maryland Community Colleges are using to track students. The SPR measures new students who have attempted 18 credit hours within the first two years after matriculation at a Maryland Community College, have either graduated or transferred, or those who have not met that criteria, but have completed 30 credit hours with a GPA or 2.00 or better and are still enrolled in school. 


\section{Chapter Three: Research Design and Method}

\section{Introduction}

The researcher examined Hispanic students who were attending community colleges and were working toward a degree. The researcher interviewed Hispanic students in the state of Maryland to determine what enabled them to attend and remain in college. The researcher studied the students’ perceptions regarding what factors helped to transition from secondary school to higher education. Furthermore, the researcher studied methods and programs on these campuses that were most likely directly related to student retention. The study focused on each of the following categories: (a) support initiated by family members, (b) members of students' social networks who promoted attendance in higher education, and (c) success of transition between secondary school and higher education.

This researcher examined these attributes and identified the most successful resources that contribute to decisions to persist at an institution. This researcher used Tinto's conceptual framework to determine where student attainment occurred with regard to family support, external support, and social and academic integration. This researcher believed that a qualitative study was imperative to determine first-hand what helped these students enter college as well as finish their plan of study.

In an effort to gain an understanding of the barriers Hispanic students may face when entering into higher education, the researcher conducted a preliminary literature review as presented in chapter two. The literature revealed to this examiner that a majority of Hispanic students face barriers and challenges with regard to language, socio economic status, parental support, and social integration. Furthermore, the literature revealed that many Hispanic students enter community colleges due to convenience with regard to location and the lower cost of 
school tuition. Moreover, the literature review conducted in this study revealed that many female Hispanic students entered community colleges which were close to home because of expectations and duties of these students that were expected by their families.

The researcher investigated by means of qualitative study, Hispanic students who had been successful in college and gathered information concerning barriers and challenges that they may have encountered transitioning to college and in the community college environment once they were in college. For the purpose of this study, success was defined as full-time students who had completed at least 12 credit hours or were part time students who had completed at least 12 credit hours and had attended two consecutive semesters in college. All students were currently enrolled in their respective colleges.

\section{Role of the Researcher}

The researcher is a secondary education teacher in the area of English. Although she does not teach a high population of Hispanic students, she is gradually experiencing an annual increase in the population of Hispanic students enrolled in her school. Furthermore, the researcher has experienced, first-hand, the language barrier that exists between student and teacher when a Hispanic student enters her classroom. Not only do problems exist with regard to communication, but Hispanic students also tend to struggle with the books and tests that are given to them. Moreover, the researcher has witnessed situations where Hispanic students have been forced to take standardized tests that are prepared in English. Consequently, many Hispanic students are placed in remedial courses and classes simply because they cannot read the language on the tests. During this qualitative study, the researcher interviewed Hispanic students who have been successful in higher education to determine what resources were most helpful in both secondary and higher education that helped them continue their education. By examining 
Hispanic students in community colleges in the state of Maryland, the researcher gained valuable information to assist schools at the secondary level in developing and implementing programs and services that ease the transition from secondary to higher education.

\section{Research Design}

The purpose of this qualitative study was to determine the factors that contributed to success for Hispanic students in higher education. The researcher identified Hispanic students in community colleges and determined what types of influences such as family, friends, school personnel in both secondary and higher education, and services and programs helped these students experience success and remain in school.

The study examined students at two different community colleges in Maryland where Hispanic students were enrolled. These students had attended their institutions for one year and continued to remain enrolled in the college to complete their two-year degrees or were planning to transfer to a four-year college. A list of accredited two-year institutions was obtained from the Carnegie Foundation website. The researcher obtained a contact person at each institution and asked each of the colleges for permission to conduct a study on their campuses (see Appendix A). Furthermore, the researcher asked that each of the colleges provide student names that met the study’s criteria. Once permission from the college was granted to the researcher, the researcher randomly contacted 20 of the identified students at each college and requested their participation in the study. The researcher interviewed a total of 26 students at the two community colleges in Maryland. Thirteen students were interviewed from Knowledge College and thirteen students were interviewed from Poor Folks College. Each student received a cover letter inviting his or her participation before the interviews began (see Appendix B). The researcher interviewed students to gather data on their experiences as Hispanic students in higher 
education using the protocol she created and followed- up by giving the Multigroup Ethnic Identity Measure (MEIM) (Phinney, 1992) (see Appendix C) to students. The researcher obtained permission from Dr. Phinney to use this measure (see Appendix D).

The researcher's goal was to interview at least 10 students at each college. Moreover, the researcher interviewed extra invited students since some undergraduates did not respond or declined to participate. By interviewing Hispanic students in community colleges in the state of Maryland, the researcher was able to answer the following questions:

1. What internal influences affect Hispanic students to attend college?

a. How do parents and other family members or peers of Hispanic students encourage their children to attend college?

b. What are the expectations of the family once their son or daughter attends college?

2. What external influences and supports do Hispanic students obtain from high schools?

a. What programs helped these students with transition to their higher education?

b. How are Hispanic students made aware of opportunities such as grants and financial aid while attending high school?

c. What individuals in the public school encourage Hispanic students to consider college as an option? How do they encourage them?

3. What supports and services did students obtain from the community college?

4. How socially integrated are students in the community college?

5. How integrated are students academically in the community college?

6. What challenges do Hispanic students encounter as new students in higher education? 
7. How committed are students to their career goals and the completion of their community college degree?

Strauss and Corbin (1990) define qualitative research as any kind of research that produces findings that are not arrived at by means of statistical procedures or other means of quantification. They further report that in order to successfully conduct qualitative research, the researcher must have the ability to critically analyze situations, to recognize and avoid bias, to obtain valid and reliable date, and to think abstractly. Yin (2003) stresses that research design is the logic that links the data to be collected with the conclusions and reflects the initial questions of study.

Patton (2002) discusses that there are three kinds of qualitative data. These include:

1. Interviews, which are open-ended questions and probes, which yield in-depth responses about people’s experiences, perceptions, opinions, feelings, and knowledge. This data consist of verbatim quotations with sufficient contact to be interpretable.

2. Observations which are a fieldwork of descriptions of activities, behaviors, actions, conversations, interpersonal interactions, organizational of community processes, or any other aspect of observable human experiences. Data consist of field notes; rich, detailed descriptions, including the context within which the observations were made.

3. Documents, which consist of written materials and other documents from organization, clinical, or program records; memoranda and correspondence; official publications and reports; personal diaries, letters, artistic work, photographs, and memorabilia; and written responses to open-ended surveys. Data consist of excerpts from documents captured in a way that records and preserves context. 
Patton (2002) further states that it is crucial for the examiner to know that qualitative studies vary by type, purpose, and quality, and that the data for qualitative analysis typically comes from fieldwork. During this time, the researcher spends time in the setting under a study program, an organization, a community, or wherever situations of importance to a study can be observed, people interviewed, and documents analyzed.

Creswell (1994) discusses approaches that are consistent with paradigms. He explains that two approaches may be used, depending on the philosophical sophistication of the audience. Creswell emphasizes that qualitative researchers are concerned primarily with the process, rather than outcomes of products. They are interested in meaning-how people make sense of their lives, experiences, and the structures of their worlds (Creswell, 1994). Furthermore, the qualitative researcher is the primary instrument for data collections and analysis. Data are mediated through his or her human instrument, rather than through inventories, questionnaires, or machines.

Qualitative research involves field work. The researcher physically goes to the people, setting, site, or institution to observe and record behavior in its natural setting. Qualitative research is descriptive, in that the researcher is interested in process, meaning, and understanding gained through words or pictures and the process of qualitative research is inductive in that the researcher builds abstractions, concepts, hypotheses, and theories from details (Creswell, 1994). Creswell (2004) describes the role of the researcher in qualitative study as interpretative research. The researcher's biases, values, and judgment become stated explicitly in the research report. Such openness is considered to be useful and positive, and allows the researcher to gain entry to a research site and potential ethical issues that may arise (Creswell, 1994). 
Merriam (2001) defines “qualitative inquiry,” as that of which focuses on meaning in context, requires a data collection instrument that is sensitive to underlying meaning when gathering and interpreting data. Humans are best suited for this task, especially because interviewing, observing, and analyzing are activities central to qualitative research (Merriam, 2001). Moreover, it is imperative that when choosing a study design, the researcher has an understanding of the philosophical foundations underlying the type of research, taking stock of whether there is a good match between the type of research and the personality, attributes, and skills of the researcher. This will enable the researcher to become informed about the design choices available to him or her within the paradigm.

\section{Population and Sample}

Once the researcher has identified the general problem, the task becomes to select the sample (Merriam, 2001). Within all studies, numerous sites could be visited, various events or activities can be observed, several people can be interviewed, and documents can be reviewed; however, the goal of the researcher is to determine, where, when, what, and whom to observe (Merriam, 2001). Sampling in field research involves the selection of a research site, time, people, and events (Merriam, 2001).

Community colleges represent a large element of postsecondary education in the United States. According to the Carnegie Foundation for the Advancement of Teaching, (2009), there are 1,769 institutions offering a two-year undergraduate degrees and certifications. The institutions represent $40.3 \%$ of all higher education institutions. With an average enrollment of 3,796, two-year community colleges include $38.2 \%$ of all students in higher education. Within Exclusively Undergraduate Two-year colleges (ExU2), 1,078 are public, 127 are private, not for profit, and 564 are private for profit. 
For this research dissertation, the researcher examined two-year colleges in the state of Maryland. The researcher chose community colleges in the state of Maryland that were primarily undergraduate two-year colleges. The researcher chose this state because it is where she teaches and the state of Maryland is currently undergoing a growth in the Hispanic population.

The researcher examined community colleges in the state of Maryland (see Table 1). Next, the researcher used information from the Internet to determine Carnegie classification (Carnegie Foundation for the Advancement of Teaching, 2009) as well as gained information regarding population and programs that existed to assist Hispanic students in higher education. The researcher also used Peterson’s Two Year Colleges book to gain demographic information regarding student population (Fern, 2006). Furthermore, the researcher examined two-year colleges to gain further information regarding demographics and/or programs that existed in these colleges.

The researcher identified six community colleges in the state of Maryland that had at least twenty Hispanic students enrolled. The institutions selected for this study were public ExU2 colleges. The institutions were limited to representatives of the Hispanic population who fall into the ExU2 category. The colleges represented both urban and rural colleges. The researcher visited two of these community colleges. Extra institutions were included in case a particular college did not participate in this study. 
Table 1

2005 Characteristics of Selected Community Colleges

\begin{tabular}{|c|c|c|c|c|c|}
\hline Institution & $\begin{array}{l}\text { Enrollment } \\
\text { No. }\end{array}$ & $\begin{array}{l}\text { Number of } \\
\text { Hispanic } \\
\text { students } \\
\text { enrolled }\end{array}$ & Size & Location & $\begin{array}{l}\text { Undergraduate } \\
\text { Public }\end{array}$ \\
\hline $\begin{array}{l}\text { Frederick } \\
\text { Community } \\
\text { College }\end{array}$ & 4822 & 193 & M2 & $\begin{array}{l}\text { Public } \\
\text { Suburban }\end{array}$ & PT2 \\
\hline $\begin{array}{l}\text { Hagerstown } \\
\text { Community } \\
\text { College }\end{array}$ & 3521 & 70 & S2 & $\begin{array}{l}\text { Public } \\
\text { Rural }\end{array}$ & PT2 \\
\hline $\begin{array}{l}\text { Anne } \\
\text { Arundel } \\
\text { Community } \\
\text { College } \\
\end{array}$ & 14290 & 286 & L2 & $\begin{array}{l}\text { Public } \\
\text { Suburban }\end{array}$ & PT2 \\
\hline $\begin{array}{l}\text { Carroll } \\
\text { Community } \\
\text { College }\end{array}$ & 3115 & 62 & S2 & $\begin{array}{l}\text { Public } \\
\text { Suburban }\end{array}$ & MIX2 \\
\hline $\begin{array}{l}\text { Harford } \\
\text { Community } \\
\text { College }\end{array}$ & 5492 & 165 & M2 & $\begin{array}{l}\text { Public } \\
\text { Suburban }\end{array}$ & MIX2 \\
\hline $\begin{array}{l}\text { Allegany } \\
\text { College of } \\
\text { Maryland }\end{array}$ & 3945 & 25 & M2 & $\begin{array}{l}\text { Public } \\
\text { rural }\end{array}$ & MIX2 \\
\hline
\end{tabular}

Student participants for this study were selected by the following criteria:

1. Participants were categorized as Hispanic.

2. Participants were enrolled in any program of study which culminates in a degree or certification.

3. Students were attending either part-time or full-time.

4. Participants may be either traditional (18-22 years) or non-traditional (over 22 years)

5. Students had completed 12 credit hours as full-time or part-time students and had attended two consecutive semesters. 


\section{Development of Interview Protocol}

For this study, the researcher developed interview questions that aligned with the research questions and the literature review. The interview protocol was developed to address each of the areas where the researcher thought the students may had experienced influences or barriers which affected their decisions to enter and/or remain in college. The interview protocol consisted of open-ended questions which allowed the participants to describe their experiences in their own words. This allowed the researcher to gain knowledge because students' answers were not limited and provided more details. The interview questions included information that was specifically geared toward addressing the research questions. The interview questions corresponded with at least one research question (see Table 2). Table 2 was the original table that was developed prior to the pilot study. 
Table 2

Interview Protocol Questions Applying to Research Questions

\begin{tabular}{|c|c|c|}
\hline Research Question & $\begin{array}{l}\text { Interview } \\
\text { Question }\end{array}$ & MEIM \\
\hline $\begin{array}{l}\text { 1. What internal influences affect Hispanic } \\
\text { students to attend college? } \\
\qquad \begin{aligned} \text { a. How do parents and other family } \\
\text { members or peers of Latino } \\
\text { students encourage their children to } \\
\text { attend college? } \\
\text { b. What are the expectations of the } \\
\text { family once their son or daughter } \\
\text { attends college? }\end{aligned}\end{array}$ & $7,8,9$ & $1,3,5,6,7$ \\
\hline
\end{tabular}

2. What external influences and supports do $10,11,12$

Hispanic students obtain from high schools?

a. What programs helped these students with transition to their higher education?

b. How are Latinos made aware of opportunities such as grants and financial aid while attending high school?

c. What individuals in the public school encourage Latino students to consider college as an option? How do they encourage them?
3. What supports and services did students obtain $11,11 \mathrm{~B}, 12 \quad 4$ from the community college during their freshman year?

\begin{tabular}{llc}
\hline $\begin{array}{l}\text { 4. How socially integrated are students in the } \\
\text { community college? }\end{array}$ & $\begin{array}{l}13,14, \\
15,16,17\end{array}$ & $\begin{array}{l}2,5,6, \\
7,8,9,10\end{array}$ \\
\hline $\begin{array}{l}\text { 5. How integrated are students academically in the } \\
\text { community college? }\end{array}$ & $18,18 \mathrm{~B}, 18 \mathrm{C}$ & \\
\hline
\end{tabular}


Table 2 (continued)

Interview Protocol Questions Applying to Research Questions

7. How committed are students to their career $\quad 4,21,22$, goals and the completion of their community 22B, 23, 24

college degree?

Demographics $1,2,3,5,6 \quad 13,14,15$

\section{Pilot Study}

The researcher obtained approval from the West Virginia University’s Institutional Review Board for the Protection of Human Subjects to conduct a pilot study. A pilot study is a small-scale trial of the study (Fraenkel \& Wallen, 2000). The purpose of the pilot study was to identify and correct any problems associated with the design or protocol (Fraenkel \& Wallen, 2000). For the pilot study, the researcher contacted an institution and asked permission to interview five students (see Appendix E). The researcher asked the president of the college to provide a letter granting permission to conduct the study, and to identify students who met the criteria of the study. (see Appendix F).

Upon receipt of the institutional permission letter and student information, the researcher contacted students through a formal letter requesting their participation in the study (see Appendix G). The researcher interviewed five students utilizing the interview protocol (see Appendix H) and the MEIM (see Appendix I). As a part of the pilot study, the researcher asked the institutional representative and the participants to critique the cover letter and interview questions to identify areas that needed improvement or clarity. The researcher recorded, coded, and analyzed the participants' responses and made changes to the study design and protocol based on feedback and findings in the pilot study. 


\section{Results from the Pilot Study}

Once the researcher attained IRB approval, she conducted the pilot study, and asked the following questions about the interview protocol in order to gain clarity of students' responses.

1. What questions were unclear to you?

2. Are there any important questions that you feel I did not ask you?

3. Were there any questions that you found offensive?

4. Did the order of the questions flow smoothly?

5. Should the interview be conducted in one setting or two?

Based upon the pilot study and how the students responded, the researcher felt that she needed to add probing questions to two of the open-ended questions and move one question to the beginning of the protocol in order for the interview to flow more smoothly.

She also used the pilot study to determine the amount of time it would take each interview. All of the pilot participants suggested that the interviews should be conducted in one setting. The total length of time needed to conduct the interview was 30 minutes. Following the interview, the researcher asked the individuals within her pilot study to review the cover letter (see Appendix B) to determine if the purpose of the study was clear and if they felt that it would motivate students to participate.

Once the interview questions and the MEIM were piloted, participants were then provided information regarding the research questions and were asked if they thought that these questions were properly aligned with the protocol and the MEIM. After this discussion took place with students individually, the protocol was altered to make sure that it was aligned with the research questions 
Once the interview protocol was finalized, it was shared with the chair of the researcher's committee and the revised protocol was approved by the West Virginia University IRB committee on February 4, 2011.

Specifically, it should be noted that the following questions were altered in the protocol.

1. Questions \#8 was moved to be asked earlier in the protocol. It was obvious to the researcher after the pilot study that she should be made aware of the primary language used at home before asking students questions about their families. Furthermore, it made sense to the researcher to know whether or not a language barrier may exist prior to asking questions about challenges or barriers.

2. Question \# 10: How would you describe the place where you were raised? PROBE: Additional information-Students seemed confused about this question, so the researcher changed the question to clarify to students that that she wanted to know what their environments were like when they were children.

3. Question \# 15: What types of challenges did you face as you made your decisions to attend this college? This question originally asked students, "Did you face any types of challenges as you made your decision to attend this college? The wording in the beginning of the question was changed to elicit more student responses. The original question made it too easy to answer, "No.”

4. Question \# 27: How successful have you been in this college? (Can you describe some of your successes?)

The researcher revised the interview protocol by moving questions to the appropriate placement within the protocol and other questions were altered to properly align with the research questions (see Table 3). No revisions were made to the cover letter. 
Table 3

Revised Interview Protocol Questions Applying to Research Questions

\begin{tabular}{|c|c|c|}
\hline Research Question & $\begin{array}{l}\text { Interview } \\
\text { Question }\end{array}$ & MEIM \\
\hline $\begin{array}{l}\text { 1. What internal influences affect Hispanic } \\
\text { students to attend college? } \\
\qquad \begin{aligned} \text { a. How do parents and other family } \\
\text { members or peers of Hispanic } \\
\text { students encourage their children to } \\
\text { attend college? } \\
\text { b. What are the expectations of the } \\
\text { family once their son or daughter } \\
\text { attends college? }\end{aligned}\end{array}$ & $11,12,13$ & \\
\hline $\begin{array}{l}\text { 2. What external influences and supports do } \\
\text { Hispanic students obtain from high schools? } \\
\text { a. What programs helped these } \\
\text { students with transition to their } \\
\text { higher education? } \\
\text { b. How are Hispanics made aware of } \\
\text { opportunities such as grants and } \\
\text { financial aid while attending high } \\
\text { school? } \\
\text { c. What individuals in the public } \\
\text { school encourage Hispanic students } \\
\text { to consider college as an option? } \\
\text { How do they encourage them? }\end{array}$ & $\begin{array}{l}\text { 14, 16A, 16B, } \\
17 \mathrm{~A}, 17 \mathrm{~B}\end{array}$ & \\
\hline $\begin{array}{l}\text { 3. What supports and services did students obtain } \\
\text { from the community college during their freshman } \\
\text { year? }\end{array}$ & 18A, 18B & \\
\hline $\begin{array}{l}\text { 4. How socially integrated are students in the } \\
\text { community college? }\end{array}$ & $\begin{array}{l}19,20,21,22, \\
23,26\end{array}$ & $1-12$ \\
\hline
\end{tabular}


Table 3 (continued)

Revised Interview Protocol Questions Applying to Research Questions

5. How integrated are students academically in the 24 community college?

\begin{tabular}{ll}
\hline $\begin{array}{l}\text { 6. What challenges do Hispanic students } \\
\text { encounter as new students in higher education? }\end{array}$ & 15,25 \\
& \\
\hline $\begin{array}{l}\text { 7. How committed are students to their career } \\
\text { goals and the completion of their community } \\
\text { college degree? }\end{array}$ & $27,28 \mathrm{~A}, 28 \mathrm{~B}$, \\
\hline Demographics & $\begin{array}{l}\text { 1, 2, 3, 4, 5, 6, } \\
\text { 7, } 13,14,15\end{array}$ \\
\hline
\end{tabular}

\section{Data Collection}

The researcher identified six community colleges in the state of Maryland that met the criteria for the study. The researcher contacted the person in charge of student services or institutional research. The researcher, via letter, gained permission to conduct the study and obtain access to student demographics, institutional, financial, and academic data that are pertinent to the study.

The researcher interviewed a total of 26 students at two selected colleges. The students were reassured that all responses were confidential, and that they would not be identified. Students were also assured that participation was strictly voluntary. The students were asked to schedule a time with the researcher. The researcher conducted interviews using the protocol that she designed using open-ended questions. Although the interview protocol was identical questions for all participants, the protocol allowed for follow-up questions in order to clarify students' responses. The interviews were recorded through the researcher's notes as well as audio taped with permission from the participant. 


\section{Data Analysis and Interpretation}

Once the interviews were completed, the researcher transcribed and coded the interviews. The researcher analyzed responses and examined trends and similar experiences that participants discussed. The researcher used information to compare and contrast data from each school to determine differences and commonalities that existed between the schools. The researcher identified aspects from each of these schools which helped enhance the retention rates and success of these students in higher education.

The data analysis consisted of several steps to gain information on demographics and helpful background on each student. The researcher used mixed methods to gain a rich description of the students interviewed. First, the researcher interviewed the participants with open-ended questions. This allowed the participant not only to answer the question at hand, but also provided an opportunity for students to elaborate on their answers which gave the researcher more information. Next, the researcher administered the MEIM in order to determine how the participants perceived themselves with regard to their ethnic identity.

The researcher examined the answers provided by the participants and determined frequencies that existed among the students and the institutions. These frequencies were recorded in percentages. The researcher analyzed the data from the interviews and the MEIM and, thus, summarized how the data addresses the researcher's questions.

The researcher used multiple validation strategies (see Figure 2). Triangulation is using multiple methods for the researcher to gain a deeper, more enriched understanding of the subject. The logic of triangulation is based on the idea that no single method alone adequately solves the problem of rival causal factors. Since each method reveals different aspects of reality, multiple methods of observations must be used (Patton, 2002). Triangulation strengthens a study because 
it combines methods. The concept of triangulation was based on the assumption that any bias inherent in particular data sources, investigator, and method would be neutralized when used in conjunction with other data sources, investigators, and methods (Creswell, 2003). For this study, the researcher used rich, thick description in conjunction with the MIEM in order to establish triangulation to help readers better understand the study.

Figure 2

Triangulation Model

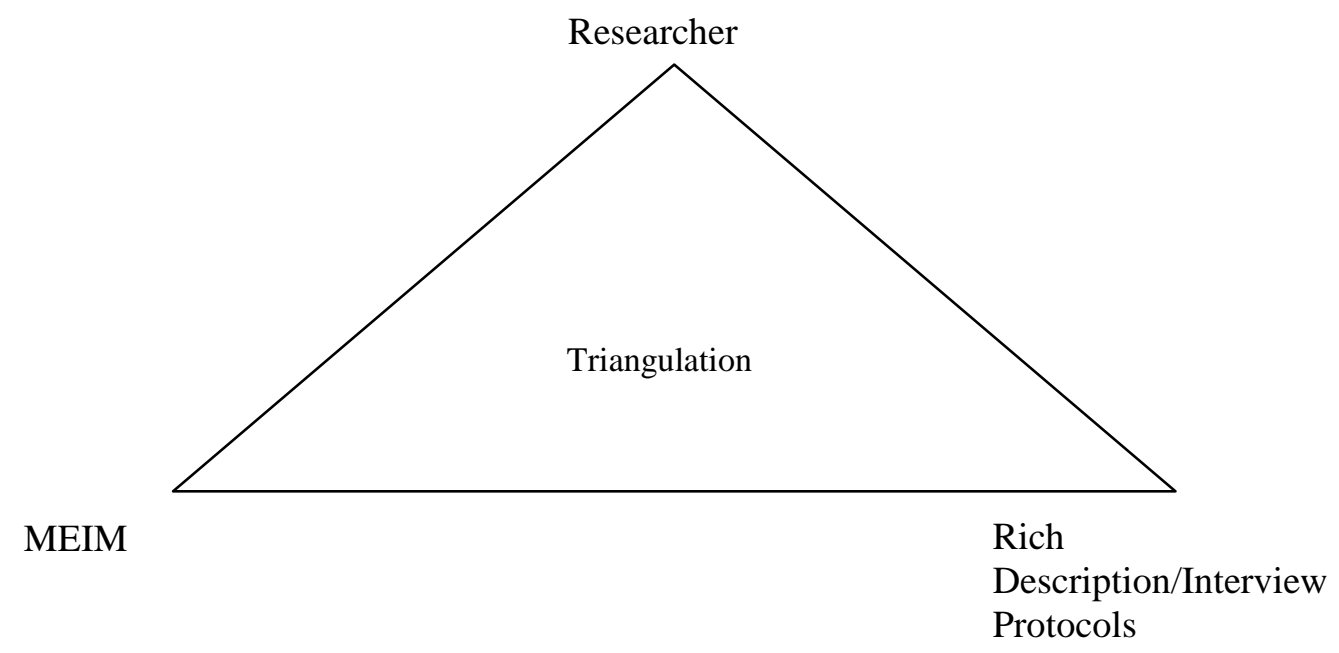

\section{Ethical Considerations}

Qualitative research provides the researcher with the opportunity to get to know the participants personally. However, this personal contact with participants can lead to revelations which may be sensitive to the participants. The researcher took the following steps in order to protect the participants’ rights: 1) present the purpose of the research including how the data would be used verbally and in writing, 2) the study maintained participant anonymity, and 3) the researcher gained approval from the West Virginia University Institutional Review Board provided an exemption. 


\section{Limitations of Study}

If a researcher wants more information about the characteristics of a given population or an area of interest, a descriptive study is in order (Merriam, 2001). Results from this study were limited to describing the phenomenon rather than predicting future behavior. Consequently, the researcher selected a case study design because of the nature of the research problem and the nature of the research questions. The case study offers a means of investigating complex social unites consisting of multiple variable of potential importance in understanding the phenomenon (Merriam, 2001). Case studies offer more insights and illuminate meanings that expand its reader’s experiences. Case studies have also proven extremely useful for studying education innovations, for evaluating programs, and for informing policy (Merriam, 2001).

Although strengths and usefulness of qualitative studies exist, there are some limitations. Although rich, thick description and analysis of a phenomenon may be desired, a researcher may not have the time or money to devote to such an undertaking (Merriam, 2001). Another limitation may be that the product may be too lengthy, too detailed, or too involved for busy policy makers and educators to read and use.

Another limitation that exists is that there were few participants in this study. Fraenkel and Wallen (2000) explain a population is more accurately represented the larger the random sample size. The small sample size of the study limited the ability to generalize the results of this study to that of the population as a whole.

A third limitation is that although the goal of this researcher was to examine what programs and services helped students achieve success, she only interviewed students who were in and have remained in college. Because she did not identify and interview students who did 
not experience success as defined by the examiner, the researcher may have gotten into the depth of the existing problems that many Hispanic student may have encountered.

A fourth limitation is that the researcher only examined two, community colleges in the state of Maryland. Although this may be an adequate representation for the state of Maryland, it may be difficult to generalize this information to other states that may have a higher population of Hispanic students.

A fifth limitation is that this researcher has had very little hands-on experiences with Hispanic students. Consequently, her limited knowledge of the Hispanics culture may have influenced or detracted from the ways that students may answer her questions. 


\section{Chapter Four: Knowledge College}

\section{Institutional Background}

Knowledge College is a two-year community college located in a rural area approximately twenty minutes from a major city. It has approximately 9,720 students. Knowledge College offers two-year associate degrees in the areas of Arts, Science, Applied Science, and Teaching, and numerous certificates. In addition, it offers transfer credit programs in the areas of General Studies, Nursing, Business Administration, Psychology, and English (Knowledge College website, 2010).

The college is easy to find and the campus is easy to navigate once on the main campus. The library is in the center of the campus and serves as a common site for students and faculty to work on assignments, gather information, and hold meetings. This is where the researcher was provided an office and accommodations to hold the interviews with the students. The campus atmosphere was extremely quiet and relaxing. People were friendly and welcoming. There was security at the front door, so the researcher explained why she was there. The security officers gave the researcher a tour of the building and informed the researcher to come and go as she needed (Knowledge College website, 2010).

Knowledge College presently has a total of 97 full-time faculty and 299 part-time faculty. Of the 97 full-time faculty, 45 are male and 52 are female. According to the college’s website, $8 \%$ of its full-time faculty are minorities. With regard to the part-time faculty, 131 are male and 168 are female. Ten percent of the part-time faculty are considered minorities. Furthermore, the college employs 187 full-time staff. Fifty-five are male, and 132 are female. Sixteen percent of the staff are considered minorities. The college also employs 224 part-time staff. Seventy of the 
part-time staff are male and 154 are female. Thirteen percent of the 224 employed staff are minorities (Knowledge College website, 2010).

According to Knowledge College's mission statement, Knowledge is a dynamic, open access institution that provides high quality educational experiences for the community. It promotes lifelong learning, workforce development, and social and cultural enrichment (Knowledge College, 2010).

In the researcher's opinion, this statement was accurate and depicted the attitude of the school very well. The researcher had the opportunity to meet and work with school personnel, and they were extremely helpful and assisted with gathering student information and disseminating information about the study. Moreover, they assisted the researcher with establishing times and places to meet students for interviews.

\section{Study Participants}

Thirteen Hispanic students were interviewed from Knowledge College during February, 2011. These students met individually with the researcher and answered questions from a protocol created by the researcher. After each interview, students were given the Multigroup Ethnic Identity Measure (MEIM) to determine how they rated themselves with regard to their ethnicity. All students were provided information regarding confidentiality before completing the interviews and the MEIM. Students were once again informed that their identities would be kept anonymous. Pseudonyms for the participants and their respective colleges are used to maintain confidentiality throughout the discussion of emergent themes.

As shown in Table 4, of the thirteen students interviewed, $46 \%(n=6)$ were male and $54 \%$ $(n=7)$ were female. The ages of students interviewed ranged from 18 to 44 . Overall, $77 \%$ $(n=10)$ were non-traditional students. Moreover, of this seventy-seven percent, $80 \%(n=8)$ of 
these students were female. However, it is imperative the researcher comment at this point, that although these students are considered non-traditional, many of them are from South and Latin America and are currently visiting the United States for college or have moved to the United States permanently to reside and are now attending college. Many of these students have attended college after high school, but not in the United States. Because of their ages, they now are considered non-traditional students. 
Table 4

Participants in the Study for Knowledge College

\begin{tabular}{|c|c|c|c|c|c|c|c|c|}
\hline Participant & Gender & Age & Credits & Major & GPA & Ed. Goal & $\begin{array}{l}\text { Former } \\
\text { Residence } \\
\end{array}$ & $\begin{array}{l}\text { Present } \\
\text { Residence } \\
\end{array}$ \\
\hline 1 & $\mathrm{M}$ & 20 & 12 & $\begin{array}{l}\text { Political } \\
\text { Science }\end{array}$ & 2.0 & Transfer & Colombia & $\begin{array}{l}\text { US Host } \\
\text { family }\end{array}$ \\
\hline 2 & $\mathrm{~F}$ & 22 & 12 & Business & 3.0 & Transfer & Mexico & $\begin{array}{l}\text { US host } \\
\text { family }\end{array}$ \\
\hline 3 & $\mathrm{~F}$ & 44 & 36 & Nursing & 3.5 & $2 Y$ & Texas & $\begin{array}{l}\text { House with } \\
\text { Husband }\end{array}$ \\
\hline 4 & $\mathrm{~F}$ & 24 & 27 & Nursing & 3.0 & $2 Y$ & Mexico & USA \\
\hline 5 & $\mathrm{~F}$ & 29 & 36 & Nursing & 3.7 & Transfer & California & Husband \\
\hline 6 & $\mathrm{M}$ & 24 & 42 & $\begin{array}{l}\text { Bio } \\
\text { Chem }\end{array}$ & 3.75 & Transfer & $\begin{array}{l}\text { Mexico } \\
\text { USA }\end{array}$ & Apartment \\
\hline 7 & M & 19 & 36 & Biology & 3.5 & Transfer & $\begin{array}{l}\text { Towson, } \\
\text { MD }\end{array}$ & Apartment \\
\hline 8 & $\mathrm{~F}$ & 27 & 48 & $\begin{array}{l}\text { Business } \\
\text { Manage- } \\
\text { ment }\end{array}$ & 3.86 & Unsure & Argentina & $\begin{array}{l}\text { US Host } \\
\text { family }\end{array}$ \\
\hline 9 & $\mathrm{~F}$ & 29 & $48+$ & $\begin{array}{l}\text { Bio- } \\
\text { Chem }\end{array}$ & 4.0 & Transfer & $\begin{array}{l}\text { California, } \\
\text { Oregon }\end{array}$ & Apartment \\
\hline 10 & $\mathrm{~F}$ & 24 & 36 & Unsure & 3.5 & Transfer & Mexico & Apartment \\
\hline 11 & $\mathrm{M}$ & 18 & Unsure & $\begin{array}{l}\text { Engineer- } \\
\text { ing }\end{array}$ & 4.0 & Transfer & Brazil & Apartment \\
\hline 12 & $\mathrm{M}$ & 19 & Unsure & $\begin{array}{l}\text { Criminal } \\
\text { Justice }\end{array}$ & 3.2 & Transfer & $\begin{array}{l}\text { New } \\
\text { Jersey }\end{array}$ & Apartment \\
\hline 13 & $\mathrm{M}$ & 29 & 56 & Sec. Ed & 2.5 & Transfer & Colombia & $\begin{array}{l}\text { House with } \\
\text { wife }\end{array}$ \\
\hline
\end{tabular}

Sixty-nine percent $(n=9)$ of students had earned over 27 credits, and 15\% $(n=2)$ had earned 12 credits at Knowledge College (see Table 4). Fifteen percent $(n=2)$ were unsure of the amount of credits they had earned.

Twenty-three percent $(n=3)$ of students were majoring in nursing, and all $23 \%$ of those students were non-traditional female students. Fifteen percent of the students were business 
majors, and they were also non-traditional female students (see Table 4). Twenty-three $(n=3)$ of the students were majoring in science related fields such as Biology, Bio Chemistry, and Engineering. Twenty-three percent $(n=3)$ of the students interviewed were majoring in Political Science, Criminal Justice, or Secondary Education. One student was unsure of her major. Students' grade point averages (GPA) ranged from 2.0 to 4.0. Fifteen percent $(n=2)$ of the students interviewed reported that they were currently earning a 4.0, and $15 \%(n=2)$ of the students had a GPA in the "C" range. Seventy-seven percent $(n=10)$ of the students reported that their GPAs were in the 3.0 to 3.9 range.

Ten students (77\%) reported that they plan to transfer after they finish their two-year degrees at Knowledge College (see Table 4). Two students (15\%) reported that they will not attend another college after they finish their degrees, and one student (8\%) reported that he is not sure what he will do (see Table 4).

After responding to information on age, gender, and school demographics, students were asked to describe the place where they were raised (see Table 5). Student responses varied. Table 5 illustrates the environments where they were raised. Seven students (54\%) responded that they were raised in a much friendlier environment, and that people were much more likely to talk to other people even if they did not know them. They described their environments as much more welcoming and that people are more open to talk to strangers. One student explained, It is so much different here. For example, when I was in Mexico, if we would see a student, no matter American or not, we would speak to that student. I remember one time we saw an American student in a coffee shop by herself, so a group of us approached her and asked her to join us. We took her with us and introduced her to more friends and our families. There is no way that anything like that would happen here. It is like people are 
so afraid of each other that it is kind of sad because you don't ever get to know other people. I think that because Americans are so reluctant to step outside or away from their group of friends, they really limit themselves.

Two students (15\%) responded that their cultures were much livelier and festive. One student told this by explaining,

I live in a small town, probably like 100,000. It is really diverse because of a lot of immigrants from Germany, Spain, and Italy, and we embrace our culture. We even have our annual festival that is real large; we are talking about 350,000 people attending the festival. That is called the Immigrant Festival which is at a large park, probably like this campus with 10 different restaurants from different countries where you can try the food from the country and see the people dressed in the typical costumes and dances and all that. It is a lot of fun.

Although students reported that they viewed their homes where they were raised as friendlier and more inviting, three students (23\%) also reported that they were raised in extremely hot and poor conditions. One student stated,

Where I was raised was economically arduous. It was an area that is even more dilapidated now than it was then. My parents are both immigrants, so this is where they could afford to live and where I was raised.

Another student commented,

I guess you guys would call it the $3^{\text {rd }}$ World. I lived in the mountain with a couple treed logs and a palmed roof. Where I came from, most of the country was agriculture based, so that is where most people got their money. 
Table 5

Childhood Environments

\begin{tabular}{lcc}
\hline $\begin{array}{l}\text { Interview response: } \\
\begin{array}{l}\text { Describe the place where you } \\
\text { were raised }\end{array}\end{array}$ & $\begin{array}{c}\text { Number of } \\
\text { responses } \\
\mathrm{N}=12\end{array}$ & $\begin{array}{c}\text { \% based on } \\
\text { number of } \\
\text { respondents } \\
\mathrm{N}=13\end{array}$ \\
\hline $\begin{array}{l}\text { Raised in a much friendlier } \\
\text { environment }\end{array}$ & 7 & 54 \\
\hline $\begin{array}{l}\text { Lived in a very poor } \\
\text { environment }\end{array}$ & 3 & 23 \\
\hline $\begin{array}{l}\text { Lived in a livelier } \\
\text { environment }\end{array}$ & 2 & 15 \\
\hline
\end{tabular}

Students were also asked about their parents’ educational backgrounds (see Table 6). Eight students (62\%) indicated that both of their parents had earned college degrees. Two of the students (15\%) responded that at least one of their parents had graduated from college, and three of the students (23\%) indicated that neither of their parents had attended college. One of the eight students (8\%) whose parents graduated from college explained that it was a clear expectation that he would enter college after high school because his parents attended college and that higher education was not something that was negotiated; it was just understood that it was the next step after high school. This sophomore business major expressed this by explaining,

I guess it was like something we were supposed to be. We were raised in a family where both parents went to college. It was just understood that I would graduate from high school and go to college. It was really not much of a choice decision, just something that I knew I would do.

Another student commented by discussing that his parents simply explained, 
We will make your life easy if you go to school. We will pay for everything and make sure that you have everything you need, or you can go out to the world with nothing and see what your life is like, like that. So I knew that I really didn’t have a choice.

Table 6

Parents’ Educational Backgrounds

\begin{tabular}{lcc}
\hline $\begin{array}{l}\text { Interview response: } \\
\text { Educational background of } \\
\text { parents }\end{array}$ & $\begin{array}{c}\text { Number of responses } \\
(\mathrm{N}=13)\end{array}$ & $\begin{array}{c}\text { \% based on number of } \\
\text { respondents. } \\
(\mathrm{N}=13)\end{array}$ \\
\hline $\begin{array}{l}\text { Both parents graduated } \\
\text { from college }\end{array}$ & 8 & 62 \\
\hline $\begin{array}{l}\text { One parent graduated from } \\
\text { college }\end{array}$ & 2 & 15 \\
\hline $\begin{array}{l}\text { Neither parent graduated } \\
\text { from college }\end{array}$ & 3 & 23 \\
\hline
\end{tabular}

Students were asked to discuss if there was one particular person who influenced them to attend college (see Table 7). Eight students (68\%) had already indicated that there were expectations to attend college because their parents had graduated from college, but the researcher asked students to think about who in their lives was most instrumental in assisting with the transition from high school to college. Although answers varied, eleven students (85\%) reported that their parents were most instrumental in their attending college. Of those 11 responses, 10 students (77\%) reported that it was their mothers who were most persistent and helped them with forms and gathering information. A twenty-four -year-old nursing student stated the following,

My mother was definitely most instrumental in me attending college. She made sure that I was focused on my studies. She was most forceful when it came to my studies. She was demanding, but I think it was good. She did not come from a wealthy family, so she got an education, and so it was just understood that I would do the same. 
Table 7

Influences of Family Members

\begin{tabular}{lcc}
\hline $\begin{array}{l}\text { Interview response: } \\
\text { Influences to attend college }\end{array}$ & $\begin{array}{c}\text { Number of responses } \\
(\mathrm{N}=13)\end{array}$ & $\begin{array}{c}\text { \% based upon the number } \\
\text { of respondents } \\
(\mathrm{N}=13)\end{array}$ \\
\hline Mother & 10 & 77 \\
\hline Father & 1 & 8 \\
\hline Spouse & 2 & 15 \\
\hline
\end{tabular}

Two students (15\%) reported that their spouses were responsible for helping them with the decision to attend college (see Table 7). It is important to note that these two students did not have parents who attended college. One student (8\%) explained that although he had attended college in Columbia, those credits would not transfer to America, so he and his wife decided that the only way he could teach in America was for him to go back to college. This secondary education major commented,

I guess my wife and the laws here are what influenced me most to go back to school. In Colombia, I have I don’t know how many certifications to teach, but it doesn’t mean anything here. I wanted to raise my family in America, so my wife and I decided that we would move here and I would take classes. It is very difficult sometimes because I have a full time job as a construction worker, so I have to do that first because that is what supports my family. There are some scholarships that exist to help me pay for college, but they don't put dinner on the table if you know what I mean. I know that it will take me longer just because I can’t take classes like most students, but it is a decision that we have made. 
Students were asked about their family expectations once they entered college. It was evident to the researcher that all families had expectations of their spouses or children to graduate from college (see Table 8).

Table 8

Family Expectations

\begin{tabular}{lcc}
\hline $\begin{array}{l}\text { Interview response: } \\
\begin{array}{l}\text { Expectations of family } \\
\text { members }\end{array}\end{array}$ & $\begin{array}{c}\text { Number of responses } \\
(\mathrm{N}=19)\end{array}$ & $\begin{array}{c}\text { \% based upon the number } \\
\text { of respondents } \\
(\mathrm{N}=13)\end{array}$ \\
\hline Complete four-year degree & 10 & 77 \\
\hline Complete two-year degree & 3 & 23 \\
\hline Become fluent in English & 3 & 23 \\
\hline $\begin{array}{l}\text { Take advantage of college } \\
\text { opportunity }\end{array}$ & 3 &
\end{tabular}

Ten students (77\%) discussed that their families were adamant that they complete their degrees at Knowledge and then transfer to a four-year college or university or transfer before they complete their two-year degrees to a four- year college or university (see Table 8). A nineteen-year old biology major commented, My family’s expectations for me are extremely high, trust me. They want me to become a doctor. They say that I have to go to school after I get my degree, so that I can be something higher that what they currently are.

Another student discussed that since both of his parents were physicians, that the expectations for him were not only that he become a physician, but a specialist.

Three students (23\%) responded that their families expected them to complete their twoyear degrees at Knowledge College. Three students (23\%) responded that their families expected them to become more fluent in English (see Table 8). One student discussed that her 
father wanted her to stay in America, so she could become fluent in English to get a better paying job in Mexico. Emmy Smith, a business student commented,

My parents told me about the importance of education in your life. And for, me, my personal opinion is that in your life, you have to learn because there is always something new to learn. My dad wants me to stay here in America, so I can learn English better. He told me that by improving my English skills, I can get a better job when I return to Mexico.

All three nursing students (23\%) commented that the first expectation was to complete their degrees. These are two-year degrees offered by the nursing program at Knowledge.

Three students (23\%) stated that their families expected them to take advantage of the opportunity to attend college (see Table 8). These students commented that their parents did not finish high school and, thus, attending college was not even something that was viewed as an option. John Jones, a political science major stated, My family expectation is so much higher. They want me to do something like lobbyist, attorney, or lawyer. When we first came here, the first six months I had no college because I was new here. I didn’t know the places. I didn’t know the colleges-where to go, but my mom always say, "Surf the internet and look for the nearest colleges near our apartment.” My mom helped me to this and then helped me with my applications and payment. So, she expects that I do well in school.

Ocie Cook, a nursing student explained that because of where she came, education was not always guaranteed. Furthermore, she commented, If a person was given the opportunity to get an education, the expectations for that person to take advantage of that opportunity were extremely high. Where I am from is 
very hot; the people are very poor. Ever since I was a child, my parents made sure that I knew that education was really important. That is how you progress in life. Where I come from, everyone is poor, so education is the only way you can be financially secure, so I know that because I am here, they expect me to do well.

Brett Lindskog, biochemistry major added the following,

We moved from Long Beach, California. There were gangs, so my family moved. It got pretty bad. We had a lot of drive-bys at one point. My parents moved us here to the east coast. My mom graduated high school in Mexico and my dad, I think the furthest he went was middle school in Mexico, so my parents were very set on me going to school and finish school. It was not a choice. They made sure of it. They told me that they would make my life easier if I went to school. They paid for everything, made sure that I had everything that I needed, and pretty much told me that I would end up like my brother who has a very hard life if I didn’t go to school. They have always helped me throughout my education. Anything I need for my education, they are there, but I know that they expect me to do what I need to do to pass.

Participants were asked about the reasons they decided to attend Knowledge College (see Table 9). Six students (46\%) commented that the cheap cost of Knowledge was a deciding factor when making decisions on where to attend school. The cost of one credit at Knowledge College is $\$ 82.00$. Thus, a student attending Knowledge would pay approximately $\$ 984.00$ per semester to be a full-time student (Knowledge College website). However, according to Barry Whitmore, an undecided major, the nearest university charges $\$ 4000.00$ per semester for fulltime students. He commented, 
Finances were a lot cheaper here at Knowledge. It was the only way I could afford to go to school. I also live at home, so I don't have to pay housing like I would if I went to a different school. Also, when I looked into attending another school, by the time I paid for housing and food and just stuff like hook up for the internet, it was going to be like over \$22,000 for the year so it wasn’t even an option for me to go anywhere else.

Table 9

Decision to Attend Knowledge College

\begin{tabular}{lcc}
\hline $\begin{array}{l}\text { Interview response: } \\
\text { Why students chose } \\
\text { Knowledge }\end{array}$ & $\begin{array}{c}\text { Number of responses } \\
(\mathrm{N}=16)\end{array}$ & $\begin{array}{c}\text { \% based upon the number } \\
\text { of respondents } \\
(\mathrm{N}=13)\end{array}$ \\
\hline Affordable tuition & 6 & 46 \\
\hline Close proximity to home & 5 & 38 \\
\hline Programs for host families & 3 & 23 \\
\hline Sport scholarships & 2 & 15 \\
\hline
\end{tabular}

Five students (38\%) interviewed discussed that close proximity to their homes were factors in why they are attending Knowledge College (see Table 9). Since Knowledge does not have dorms, most students either live at home or in apartments. Students discussed that housing close to campus is relatively cheap when compared to other campuses.

One student's mother had been diagnosed with cancer, so he attended Knowledge because he could still go to school and help take care of his mother at home. Unfortunately, this student had been accepted to a major university, but was unable to attend because of his mother's health. Another student discussed that she attended Knowledge because her husband's job was in the county, and it was where she could attend college and still be close to her home and her children’s school. This nursing student stated, 
It is the only school that is close by my home. We moved here so my husband could get a job. Going to another college wasn’t even a consideration for me because I need to be close to my family in case my kids would be sick or I was needed at home.

Students' responses also included that Knowledge was one of the first schools to accept them (see Table 9). Three students (23\%) reported that they are attending Knowledge because of a program that accepts students from Mexico who live with host families, and two students (15\%) indicated that they are attending Knowledge because they were accepted through sports scholarships.

Students were asked to discuss challenges that they may have encountered while attending college (see Table 10). Six students (46\%) responded that finances were a constant worry while attending college. Twenty-nine-year- old secondary education major reported, There are tons [of challenges]. It is my work schedule, my two kids, and my wife. I have to provide for them before I can study, so the challenges are mainly just the work and family life and the cost of it all, not the education. I can handle my class work really well.

One student discussed that his economic situation had changed, so he could not afford a "big college” for now. Consequently, his major challenge at this point was finances. Political Science major Woodrow Broome commented,

I was away from here. I have attended a university but I could no longer afford the high tuition and pay for everything, so I had to call my parents and come home, so they were like all right and set up my room for me and everything. I am sure that I will go back to the university again because I want to get a four-year degree. 
Three (23\%) students discussed that juggling work, family and school was extremely challenging (see Table 10). Three students (23\%) discussed that the English language was a challenge that they encountered when first attending college.

Table 10

Challenges Students Encountered

\begin{tabular}{lcc}
\hline $\begin{array}{l}\text { Interview response: } \\
\text { Challenges students have } \\
\text { encountered }\end{array}$ & $\begin{array}{c}\text { Number of responses } \\
(\mathrm{N}=15)\end{array}$ & $\begin{array}{c}\text { \% based upon the number } \\
\text { of respondents } \\
(\mathrm{N}=13)\end{array}$ \\
\hline Finances & 6 & 46 \\
\hline Work schedule & 3 & 23 \\
\hline Family & 3 & 23 \\
\hline Language barrier & 3 & \\
\hline
\end{tabular}

Students were questioned about what kind of support they received in high school, or if any programs existed in high school that helped them decide to attend college or where to attend college (see Table 11). Five students (38\%) responded that they received no help or guidance to attend college while they were in high school. A twenty-nine- year-old nursing student Constance Shaffer commented,

There was a lot of information there, but right out of high school, I really didn’t get any. There wasn't anybody there who told me where to go or what to apply for. I really didn't know much of anything until I was older and decided to go to school. 
Table 11

High School Programs and Services

\begin{tabular}{lcc}
\hline $\begin{array}{l}\text { Interview response: } \\
\text { Personnel, programs, or } \\
\text { services in high school }\end{array}$ & $\begin{array}{c}\text { Number of responses } \\
(\mathrm{N}=15)\end{array}$ & $\begin{array}{c}\text { \% based upon the number } \\
\text { of respondents } \\
(\mathrm{N}=13)\end{array}$ \\
\hline None & 5 & 38 \\
\hline School counselor & 5 & 38 \\
\hline Special programs & 3 & 15 \\
\hline $\begin{array}{l}\text { Athletic } \\
\text { scholarships/programs }\end{array}$ & 2 & \\
\hline
\end{tabular}

Five students (38\%) responded that they were provided information through their guidance counselors at school; however, only one of those students responded that she received specific information regarding scholarships for Hispanic students. This forty-four year old nursing student commented,

Where I was from in Texas, there were Hispanic scholarship programs for college. Like I said, I grew up in San Antonio, which I would say is 50\% Hispanic, 50\% Caucasian and a little mix of everything else. Consequently, there was a lot of support where I went to school, in high school, to try to move forward. However, since I am married and have moved around a lot, I wouldn't say that having these same opportunities are the case. Kids here do not have the same opportunities that I had. I think it is just very unique to Texas. Here students are made aware of scholarships, but they are not because of any particular ethnicity. Because I am an adult and aware of my own kids' needs, I am much more aware of these scholarships than my classmates.

One student (8\%) responded that his private school was geared toward putting students in a college track. He explained, 
Well, I went to a private school, so the programs at the school oriented you to definitely go to college and get into good colleges. We took classes that prepared us for college. This definitely helped because, so far, I think my classes here are pretty easy. Three students (23\%) who lived with host families discussed that their schools had special programs that gave information about various colleges they could attend in America (see Table 11). A twenty-two-year-old business major commented, In Mexico I was studying in a private high school, so they had a special week where you would go to university and ask for information, and they would come to the high school and you would take the test about to get in. So it is easy in Mexico to get information about the universities. They encourage you to continue your education, just not the major-even more majors like master's and Ph.D.

Two students (15\%) reported that they received information in their high schools about athletic programs that existed in colleges.

Students were asked to report whether or not they received financial aid or any other assistance while they were in college (see Table 12). Five (38\%) students indicated that they did not receive financial aid or any other kind of assistance. Five students (38\%) reported that they were receiving financial aid. Three students (23\%) reported that they were receiving Pell grants. Two students (15\%) indicated that they were received some assistance through athletic scholarships. One student (8\%) reported that he was working for tuition. One student (8\%) reported that he received free tuition through the army (see Table 12). After further discussion with students, this researcher learned that one of the students was aware that he was receiving some type of financial aid, but he had no idea what it was.

This second-year biology student stated, 
Yes, I am receiving a grant, but I am honestly not too sure. I have one Pell; I have a couple of stuff. I guess I have financial aid because I played soccer here. Technically it is not financial aid because it is from the coach.

Table 12

Sources of Financial Support

\begin{tabular}{lcc}
\hline $\begin{array}{l}\text { Interview response: } \\
\begin{array}{l}\text { Students receiving help } \\
\text { with paying for college }\end{array}\end{array}$ & $\begin{array}{c}\text { Number of responses } \\
(\mathrm{N}=17)\end{array}$ & $\begin{array}{c}\text { \% based upon the number } \\
\text { of respondents } \\
(\mathrm{N}=13)\end{array}$ \\
\hline None & 5 & 38 \\
\hline Financial aid & 5 & 23 \\
\hline Pell grants & 3 & 15 \\
\hline Athletic scholarships & 2 & 8 \\
\hline $\begin{array}{l}\text { Working at the college for } \\
\text { tuition }\end{array}$ & 1 & 8 \\
\hline Free tuition through the army & 1 & \\
\hline
\end{tabular}

Students were asked about the services and programs available for them to use at Knowledge College (see Table 13). Eleven students (85\%) reported that they use the library more than any other resources that are available. Jennie Ack, a business management major, reported,

I probably use the library the most. I use it all the time. I come here and use the computers and books. Plus, there are people here too who help you when you have an assignment, and they already know where everything is , so I just go to them and it saves me a lot of time.

An athlete Marvin Proietti stated, 
Well, I guess the library and the labs that we can use here at the campus. I also go to the gym and the court. But mostly, I just meet the other players here at the library, and we do our work together. That's how we get our work done. Students also commented that other than the library, they have the luxury of e-mailing their professors and working on-line with them.

One student commented,

I use the library and computers and just talking to my professors helps, but most of all, I email my professors. That has been helping me a lot because I can email at certain times when I am not working. It is more convenient for me to email when I have the time. They always get back to me. I know that won't happen at the university that is nearby, so I know that I am very fortunate to have professors who care to email me back.

Table 13

Services Used

\begin{tabular}{lcc}
\hline $\begin{array}{l}\text { Interview response: } \\
\text { Services students use at } \\
\text { Knowledge College }\end{array}$ & $\begin{array}{c}\text { Number of responses } \\
(\mathrm{N}=15)\end{array}$ & $\begin{array}{c}\text { \% based upon the number } \\
\text { of respondents } \\
(\mathrm{N}=13)\end{array}$ \\
\hline Library & 11 & 85 \\
\hline Tutoring & 2 & 15 \\
\hline Interaction with faculty & 2 & 15 \\
\hline
\end{tabular}

Two students (23\%) commented that they use the tutoring center (see Table 13). One student commented that although she knows there is a tutoring center available, she has not needed to use it at this time. 
Students were asked about how socially connected they felt to other students and faculty members at Knowledge (see Table 14). Students' responses varied. Thirteen students (100\%) reported that they felt socially connected to the faculty at Knowledge College (see Table 14).

Table 14

Social Connections

\begin{tabular}{lcc}
\hline $\begin{array}{l}\text { Interview response: } \\
\text { How socially students feel } \\
\text { Connected to the college }\end{array}$ & $\begin{array}{c}\text { Number of responses } \\
(\mathrm{N}=28)\end{array}$ & $\begin{array}{c}\text { \% based upon the number } \\
\text { of respondents (N=13) }\end{array}$ \\
\hline $\begin{array}{l}\text { Feel socially connected to } \\
\text { faculty }\end{array}$ & 13 & 54 \\
\hline $\begin{array}{l}\text { Feel socially connected to } \\
\text { students }\end{array}$ & 7 & 31 \\
\hline $\begin{array}{l}\text { Do not feel socially } \\
\text { connected to students }\end{array}$ & 4 & 31 \\
\hline $\begin{array}{l}\text { Do not feel socially } \\
\text { connected to Hispanic } \\
\text { students }\end{array}$ & 4 & \\
\hline
\end{tabular}

Seven students (54\%) felt that they were socially connected to students at the college (see Table 14). A nineteen-year-old soccer student commented,

Pretty connected. I have no problem going up to people and everyone kind of knows me. I am lucky because I am on the soccer team, but it just takes time and when you are on a team or something like that, it is better, because you can make friends easier.

With regard to faculty connections, a twenty-nine-year-old biology-chemistry major stated, They care a whole lot, especially because I went on vacation for a week one time, and I got really sick. I wasn't able to go to school at all for two weeks or something like that and they didn't take off any points or anything. They just helped me catch up, and they kept me after class and everything, so it was cool.

Four students (31\%) said that they did not feel socially connected to students at the college (see Table 14). For example, a twenty-four-year-old bio-chemistry major explained, 
No, not really. Everyone kind of leaves you alone here. It is very quiet, like it was when I was little. I kind of like that, but it doesn't give you a lot of time to meet people. Like I go to the café to watch sports, but everybody is already in their groups, so I don't really get to know anybody here. I think that it will be better when I go to Delaware because a lot of my friends are there.

Four students (31\%) commented that they felt connected to students, but not necessarily with the Hispanic population (see Table 14). A twenty-four year old Jennifer Raines commented,

I feel connected to my peers in the nursing program. We have had so many of our classes together that we kind of have our own family, but no, I do not feel connected to any Hispanic students. I have seen several on campus, but it's not like I know them outside of seeing them here.

A host student, Emmy Perry further explained, No, not at all to the Hispanic population. That is one thing I miss here. I thought that when I came on campus, there would be some type of organization or something for people in this program to get to know other people. But, there is nothing like that here. I wish that there was something because although my host family is very good to me, I would like to meet some people, you know, who are my-age people I could see on weekends.

And I really think that something would be good to introduce us to people on the campus. I have gone to the café several times, but it is like groups are so separate there. I mean the Black population and the White population are separated there. That is really strange to me. 
Students were questioned about social connections they had with regard to students, faculty, and clubs (see Table 15). Although students overwhelmingly reported that they felt socially connected to students and faculty, they did not see, and they were not aware of many other Hispanic students on campus. One student commented,

I would say that the opportunities are out there for them, but that because there is no active participation, nobody is really looking for them, nobody is trying to encourage them to come, that because of that, they are not going to do it on their own. A lot of times, the language barrier is so significant that they just don't have that opportunity to do so. I think if someone found their way to Knowledge College, they would be well taken care of, but nobody is going to go look for them and they don't know that that opportunity is there, so it is like something missing. The in between person is missing for them to get there. I probably would say I am the $1 \%$ in school. I have not seen another person who is of Hispanic origin, maybe there is and I just don't know it. Eight students (62\%) responded that they were not aware of any clubs at Knowledge College (see Table 15). Two students (15\%) responded that they were aware of some clubs on campus, but that they did not participate in any. Two students (15\%) reported that they were members of athletic clubs, and only one (8\%) student reported that she was a member of the Multicultural Students Organization (MSA). A nineteen-year-old criminal justice major said, There are so many clubs, but currently I am not a member of any of them. But, I am not aware of any clubs for Hispanic students. I know that there are other Hispanic students on campus, but I really do not know them. I think it would be nice to get to know them. You know when you go to the café, you see a lot of White students congregating 
watching sports, basketball and football. However, you never really see a group of Hispanic students together in the cafe. I think I would like that.

Table 15

Club Participation

\begin{tabular}{lcc}
\hline $\begin{array}{l}\text { Interview response: } \\
\text { Do students participate in } \\
\text { clubs? }\end{array}$ & $\begin{array}{c}\text { Number of responses } \\
(\mathrm{N}=13)\end{array}$ & $\begin{array}{c}\text { \% based upon the number } \\
\text { of respondents } \\
(\mathrm{N}=13)\end{array}$ \\
\hline Are not aware of clubs & 8 & 62 \\
\hline $\begin{array}{l}\text { Aware but do not } \\
\text { participate in clubs }\end{array}$ & 2 & 15 \\
$\begin{array}{l}\text { Participate in college } \\
\text { Sports }\end{array}$ & 2 & 15 \\
\hline Participate in clubs & 1 & 8
\end{tabular}

An engineering student Zachary Ashby commented,

Not really, I guess no. I mean again, I wish I would know more Hispanic students, but right now, I don't have time for a big social life anyway, so I don't know you know if I would have time, but I would like to meet new people and I always like to learn more about different cultures, so if there was a club for Hispanics, I would definitely join.

One student commented, "I'm not sure. Don't they have like an Asian or Hispanic club-I made that up. I'm not sure."

Students were asked how much they enjoy their classes at Knowledge College and whether or not they felt that their instructors cared about their classes (see Table 16). Five students (38\%) reported that they enjoyed their classes, and that they feel that their professors care about their progress. A business management major commented,

Yes, I enjoy my classes very much. I am learning a lot, but I am only taking a few classes right now because I need to focus on my writing class. That is very 
difficult for me. The class is "fast paced," so I have to spend a lot of time with the tutor and working outside of the class to pass the class. My professor talks to me about making sure that I work with the tutor, so I can pass.

Four students (31\%) reported that they love their classes (see Table 16).A twenty-nine-year-old nursing student explained,

All the instructors are just very devoted to the students and do try to work hard to get their students to do well. However, I think that you get to a point to whether you either do it or you don't. In nursing, you get to a point where you either pass or fail. The instructors will help you, but at some point, you have to have the knowledge.

A twenty-two year-old political science teacher noted,

The math and the English teacher always talk to me. If I am doing okay and need some help, they help me. They will work with be in their offices to make sure that I understand. Although, I go to tutoring and do that sometimes, I like it better to go to them because they know exactly what we have done in class. So far, I think that this has helped me the best. They are used to me now. They are not surprised when they see me. I am doing well in both of their classes.

Table 16

Classes at Knowledge

\begin{tabular}{lcc}
\hline $\begin{array}{l}\text { Interview response: } \\
\text { How students feel about } \\
\text { classes }\end{array}$ & $\begin{array}{c}\text { Number of responses } \\
(\mathrm{N}=14)\end{array}$ & $\begin{array}{c}\text { \% based upon the number } \\
\text { of respondents }(\mathrm{N}=13)\end{array}$ \\
\hline Enjoy classes & 5 & 38 \\
\hline $\begin{array}{l}\text { Feel that professors } \\
\text { Care about their progress }\end{array}$ & 5 & 31 \\
\hline Love classes & 4 & 38 \\
\hline
\end{tabular}


Students were asked if they had encountered any obstacles while attending college (see Table 17). Six students (46\%) reported that finances were a constant concern. Most of the students interviewed were non-traditional students, so they previously had jobs for money to attend school or were currently working so that they could afford school. A forty-four-year-old nursing student commented,

I have two kids, so my husband and I struggle to make sure that they have everything they need and still pay for all of the costs that come with the typical cost of living. We look forward to when I am actually earning a salary and we are not worried about paying for the next tuition and our basic family needs too.

Four students (31\%) commented that time management is a constant concern for them in college (see Table 17). Students commented that keeping up with their classes and a work schedule is difficult. Three students (23\%) commented that English was definitely an obstacle that they had to overcome. A twenty-year-old business major commented, The language has definitely been an issue for me, but that is partly why I am here. I knew that when I came to the U.S., I would struggle with my English. My family here is so helpful and they try to work with me for my assignments, but I would say that has been the main obstacle for me. 
Table 17

Obstacles at Knowledge

\begin{tabular}{lcc}
\hline $\begin{array}{l}\text { Interview response: } \\
\begin{array}{l}\text { Obstacles students } \\
\text { encountered at Knowledge }\end{array}\end{array}$ & $\begin{array}{c}\text { Number of responses } \\
(\mathrm{N}=13)\end{array}$ & $\begin{array}{c}\text { \% based upon the number } \\
\text { of respondents (N=13) }\end{array}$ \\
\hline Finances & 6 & 38 \\
\hline Time management & 4 & 23 \\
\hline Language & 3 &
\end{tabular}

Students were asked if they could teach people at Knowledge College about their culture, what they would teach them (see Table 18). Two students (15\%) commented that they would teach people to disregard stereotypes. A forty-four- year-old nursing student discussed,

I would teach them that Hispanic people are not just laborers, and that a lot of times they do come over here and they do have other things that they can contribute, but I think as a whole people see Hispanics as just being laborers and that is all they can do. They are just not aware of all the possibilities that people can still contribute given the opportunity. Not that they all come here with being able to do a lot of stuff, but if they were given the opportunity, I think that they would be able to contribute.

A secondary-education major Anthony Looney commented,

That it is not about drugs and coffee in Columbia. It is not a trap or a dangerous place anymore. Besides the coffee and the other stuff, they have roses, textiles, gold, platinum, emeralds. They have abundant resources, but people only think coffee and drugs.

A host student, Jenna Summers, contributed,

I would probably teach them that South Americans in general are all kind of hybrids, that people don't have a clear, you know [student paused] when my whole life they have those 
check boxes of Asian and Pacific Island and Hispanics from Mexico find it easier, but Hispanics from South America are more often than not; some look like me, some are black some are light skinned because everyone is mixed together over a long time, so cultural identity is a bit more oblique for them. I think most people don't know that about South America.

Three students (23\%) commented that they would teach others that their culture is much friendlier and inviting to others. Two students (15\%) stated that they would like to teach others why Hispanic people want to come to the United States (see Table 18).

Table 18

Education of Culture

\begin{tabular}{lcc}
\hline $\begin{array}{l}\text { Interview response: } \\
\begin{array}{l}\text { What students would teach } \\
\text { others about their culture }\end{array}\end{array}$ & $\begin{array}{c}\text { Number of responses } \\
(\mathrm{N}=9)\end{array}$ & $\begin{array}{c}\text { \% based upon the number } \\
\text { of respondents } \\
(\mathrm{N}=13)\end{array}$ \\
\hline Food & 3 & 23 \\
\hline Awareness of stereotypes & 2 & 15. \\
\hline Friendly atmosphere & 2 & 15 \\
\hline $\begin{array}{l}\text { Why we want to come to } \\
\text { the U.S. }\end{array}$ & 2 & \\
\hline
\end{tabular}

Students were questioned about how whether or not they had any experiences that made them more aware of their ethnic background (see Table 19). Seven students (54\%) responded that they had experienced situations where they were treated differently because of their ethnicity (see Table 19). Students discussed that because Spanish was their first language, people sometimes had looked at them oddly because of the accents. Students also commented that, at time, people seemed offended because of their accents. 
Table 19

Ethnicity Experiences

\begin{tabular}{lcc}
\hline $\begin{array}{l}\text { Interview response: } \\
\text { Awareness of ethnicity }\end{array}$ & $\begin{array}{c}\text { Number of responses } \\
(\mathrm{N}=18)\end{array}$ & $\begin{array}{c}\text { \% based upon the number } \\
\text { of respondents (N=13) }\end{array}$ \\
\hline Treated differently & 7 & 54 \\
\hline None & 6 & 23 \\
\hline Language & 3 & 15 \\
\hline Racial profiling & 2 & \\
\hline
\end{tabular}

One of these seven students commented that although she really liked her professor, she was told from the beginning that she may struggle in the class because it was an Italian course, so the professor told her the language barrier may present challenges. This business student explained,

Last semester my teacher was an Italian woman. She has an Italian background. She speaks American. Her parents were from Italy, so she told me from the beginning I was going to have a hard time with English because people attending here, the first language is English and I was Spanish. She told me, "You are going to have to do your best and if you need something, to tell me, but I recommend you bring your dictionary, and I cannot wait for you to get all the information, so you have to work." Then at the end, she was surprised because I was improving my writing, so she told me the last class before the final test, I don't want you to fail the class because I know that you are doing your assignments with help because I can tell in your writing. So the last two essays you have to do by yourself, so I am not sure if you can and I say my last essays I did by myself because I didn't have time to come to the tutoring, so these are mine. So, she say oh 
really, I see that you are improving, but anyway I don't want to you to come without hope that you are going to pass. I am sure that I did a great job on the last two essays and the final. Sometimes people don't trust you about your capacity to adapt.

A twenty-two-year- old business major discussed her situation by explaining,

The times I have to speak in public, that fact that I have an accent and the reaction sometimes. Most of the people don't really care, but I see sometimes different reactions. I don't know if it is ethnicity or race. I don't really think of them as the same.

Six students (46\%) responded that they had not had any experiences that made them aware of their ethnic identities or if they did, it did not affect them (see Table 19). Three students (23\%) responded that not knowing the English language made them more aware of their ethnicity and two students (15\%) that they were made aware of their ethnicity because of racial profiling. One student explained this by commenting about the first college he attended, Yes, definitely, at my first college because my college was incredibly colored, but I think visiting friends at more White colleges, like Loyola College in Baltimore, you were definitely a bit of an outsider. I remember a time that I was visiting a girlfriend of mine, and I was outside of the apartment building in Loyola. Loyola is a small private Catholic college. I had a bunch of friends there, and I had actually finished for the semester, and I had bought myself a new car. Campus police came because I was walking around in front of the apartment building, and thought I was like checking out which places to rob because the semester was ending. They demanded identification and called the police, and it was pretty bad.

Students were asked if they thought about whether being Hispanic affected their lives right now (see Table 20). Seven students (54\%) reported that they did not feel as though their 
lives were affected in any way (see Table 20). Three students (23\%) responded that they their lives were changing because they were getting an education and start their careers, but not they were being affected because they were Hispanic. One student (8\%) responded that she did not feel that her life was being affected because she was Hispanic, but that her life was being affected because she was given the opportunity to come to America. This business student explained,

I guess I feel affected/lucky because I have been given this opportunity to come to the U.S. It makes me appreciate being Hispanic. I really like it here. Everyone has been great, but I really miss my culture. I miss the [relaxation] of not always being in a hurry like people are here. Of course, I miss my family, but I think most of all, I miss my [um, I'm not sure how to say this] my being comfortable. I'm sorry. I'm not quite sure how to say that.

Table 20

Affects of Being Hispanic

\begin{tabular}{lcc}
\hline $\begin{array}{l}\text { Interview response: } \\
\text { How is life affected by being }\end{array}$ & $\begin{array}{c}\text { Number of responses } \\
\text { Hispanic }\end{array}$ & $\begin{array}{c}\text { \% based upon the number } \\
\text { of respondents } \\
(\mathrm{N}=13)\end{array}$ \\
\hline Not affected & 7 & 56 \\
\hline Getting an education & 3 & 23 \\
\hline $\begin{array}{l}\text { Opportunity to live in } \\
\text { America }\end{array}$ & 1 & 8 \\
\hline
\end{tabular}

Students were asked if their feelings as a Hispanic had changed since they entered college (see Table 21). Eight students (62\%) responded that their feelings had not changed and that they have always been aware of their ethnicity, but that they felt more proud of the being in college. A Mexican business student commented, 
No, my feelings have not changed at all. I would actually miss my culture and the things

I would do daily. I miss the music and celebrations. We seem to have more celebrations than what they do in the United States.

Three students (23\%) commented that they became more aware because of the way that people are separated by groups in America (see Table 21). An Argentinean student commented, No, they have not changed since I came to the states because I never thought about my race before, never. In Argentine, we have a lot of different races, but we are all Argentinas. We are not Italian Argentinas. We are not Spanish Argentinas or African Argentinas. That just sounds ridiculous to us. We are all Aregentinas. You are in the place that you were born, so I never thought about that before.

Table 21

Ethnicity Awareness

\begin{tabular}{lcc}
\hline $\begin{array}{l}\text { Interview response: Change } \\
\text { in Awareness of Ethnicity }\end{array}$ & $\begin{array}{c}\text { Number of responses } \\
(\mathrm{N}=13)\end{array}$ & $\begin{array}{c}\text { \% based upon the number } \\
\text { of respondents } \\
(\mathrm{N}=13)\end{array}$ \\
\hline Nothing has changed & 8 & 62 \\
\hline Aware of differences & 3 & 23 \\
\hline More in-tune with self & 2 & 15 \\
\hline
\end{tabular}

Two students (15\%) commented that they were more aware and proud of their ethnicity resulting in positive feelings (see Table 21).

Students were asked to discuss whether they thought they would continue to attend college in consecutive semesters until they completed their degrees. Thirteen students (100\%) interviewed were committed to completing either a two-or four-year degree. Although some students reported that finances are definitely an issue, all students said that they would continue 
to enroll in consecutive semesters until they complete a program. Students discussed that once they made the decision to attend college that they were committed to completing their degrees.

\section{Multigroup Ethnic Identity Measure}

The researcher asked students to complete Jean Phinney's Model of Ethnic Identity (1999). Using Likert scale responses, students identified how they felt about themselves individually and as a group.

This researcher believes that ethnic identity is essential to the development of a positive self-concept for minority students. It helps students by developing from a shared culture, religion, geography, and language and connects by a strong loyalty and kinship.

Phinney's model (1999) discussed two stages (factors) for students. Ethnic Identify Search (questions 1, 2, 4, 8, and 10) and Affirmation, Belonging, and Commitment (questions 3, 5, 6, 7, 9, 11, 12). Questions 13, 14, and 15 are identification and categorization demographic questions. The MEIM questions are scored on a Likert-type scale with scores ranging from 4, strongly agree to 1 , strongly disagree.

\section{Multigroup Ethnic Identity Measure Results}

When asked about whether students have spent time to learn more about their ethnic group and its history, traditions, and customs, four students (31\%) reported that they strongly agreed, six students (46\%) agreed, and three students (23\%) disagreed that they had done this (see Table 22).

When asked if students were active in organizing social groups that included mostly members of their own ethnic group, six students (46\%) strongly agreed that they had. Four students (31\%) agreed that they had, and three students (23\%) disagreed (see Table 22). 
Table 22

Knowledge College MEIM Responses

\begin{tabular}{|c|c|c|c|c|}
\hline Item & $\begin{array}{l}4 \\
\text { SA } \\
\% \text { based on } \\
\text { the number of } \\
\text { responses } \\
(\mathrm{N}=13)\end{array}$ & $\begin{array}{l}3 \\
\text { A } \\
\% \text { based on the } \\
\text { number of } \\
\text { responses } \\
(\mathrm{N}=13)\end{array}$ & $\begin{array}{l}2 \\
D \\
\% \text { based on the } \\
\text { number of } \\
\text { responses } \\
(\mathrm{N}=13)\end{array}$ & $\begin{array}{l}1 \\
\mathrm{SD} \\
\% \text { based on the } \\
\text { number of } \\
\text { responses } \\
(\mathrm{N}=13)\end{array}$ \\
\hline $\begin{array}{l}\text { I have spent time trying to find } \\
\text { out more about my ethnic groups } \\
\text { such as its history, traditions, and } \\
\text { custom. }\end{array}$ & $\begin{array}{l}31 \\
(\mathrm{~N}=4)\end{array}$ & $\begin{array}{l}46 \\
(\mathrm{~N}=6)\end{array}$ & $\begin{array}{l}23 \\
(\mathrm{~N}=3)\end{array}$ & $\begin{array}{l}0 \\
(\mathrm{~N}=0)\end{array}$ \\
\hline $\begin{array}{l}\text { I am active in organizations or } \\
\text { social groups that include mostly } \\
\text { members of my own ethnic } \\
\text { groups. }\end{array}$ & $\begin{array}{l}46 \\
(\mathrm{~N}=6)\end{array}$ & $\begin{array}{l}31 \\
(\mathrm{~N}=4)\end{array}$ & $\begin{array}{l}23 \\
(\mathrm{~N}=3)\end{array}$ & $\begin{array}{l}0 \\
(\mathrm{~N}=0)\end{array}$ \\
\hline $\begin{array}{l}\text { I have a clear sense of my ethnic } \\
\text { background and what it means } \\
\text { for me. }\end{array}$ & $\begin{array}{l}77 \\
(\mathrm{~N}=10)\end{array}$ & $\begin{array}{l}23 \\
(\mathrm{~N}=3)\end{array}$ & $\begin{array}{l}0 \\
(\mathrm{~N}=0)\end{array}$ & $\begin{array}{l}0 \\
(\mathrm{~N}=0)\end{array}$ \\
\hline $\begin{array}{l}\text { I think a lot about how my life } \\
\text { will be affected by my ethnic } \\
\text { group membership. }\end{array}$ & $\begin{array}{l}15 \\
(\mathrm{~N}=2)\end{array}$ & $\begin{array}{l}46 \\
(\mathrm{~N}=6)\end{array}$ & $\begin{array}{l}31 \\
(\mathrm{~N}=4)\end{array}$ & $\begin{array}{l}0 \\
(\mathrm{~N}=1)\end{array}$ \\
\hline $\begin{array}{l}\text { I am happy that I am a member } \\
\text { of the group I belong to. }\end{array}$ & $\begin{array}{l}92 \\
(\mathrm{~N}=12)\end{array}$ & $\begin{array}{l}8 \\
(\mathrm{~N}=1)\end{array}$ & $\begin{array}{l}0 \\
(\mathrm{~N}=0)\end{array}$ & $\begin{array}{l}0 \\
(\mathrm{~N}=0)\end{array}$ \\
\hline $\begin{array}{l}\text { I have a strong sense of } \\
\text { belonging to my own ethnic } \\
\text { group. }\end{array}$ & $\begin{array}{l}69 \\
(\mathrm{~N}=9)\end{array}$ & $\begin{array}{l}31 \\
(\mathrm{~N}=4)\end{array}$ & $\begin{array}{l}0 \\
(\mathrm{~N}=0)\end{array}$ & $\begin{array}{l}0 \\
(\mathrm{~N}=0)\end{array}$ \\
\hline $\begin{array}{l}\text { I understand pretty well what my } \\
\text { ethnic group membership means } \\
\text { to me. }\end{array}$ & $\begin{array}{l}69 \\
(\mathrm{~N}=9)\end{array}$ & $\begin{array}{l}31 \\
(\mathrm{~N}=4)\end{array}$ & $\begin{array}{l}0 \\
(\mathrm{~N}=0)\end{array}$ & $\begin{array}{l}0 \\
(\mathrm{~N}=0)\end{array}$ \\
\hline $\begin{array}{l}\text { In order to learn more about my } \\
\text { ethnic background, I have often } \\
\text { talked to other people about my } \\
\text { ethnic group. }\end{array}$ & $\begin{array}{l}46 \\
(\mathrm{~N}=6)\end{array}$ & $\begin{array}{l}38 \\
(\mathrm{~N}=5)\end{array}$ & $\begin{array}{l}15 \\
(\mathrm{~N}=2)\end{array}$ & $\begin{array}{l}0 \\
(\mathrm{~N}=0)\end{array}$ \\
\hline $\begin{array}{l}\text { I have a lot of pride in my ethnic } \\
\text { group. }\end{array}$ & $\begin{array}{l}85 \\
(\mathrm{~N}=11)\end{array}$ & $\begin{array}{l}15 \\
(\mathrm{~N}=2)\end{array}$ & $\begin{array}{l}0 \\
(\mathrm{~N}=0)\end{array}$ & $\begin{array}{l}0 \\
(\mathrm{~N}=0)\end{array}$ \\
\hline $\begin{array}{l}\text { I participate in cultural practices } \\
\text { of my own groups, such as } \\
\text { special food, music or customs. }\end{array}$ & $\begin{array}{l}62 \\
(\mathrm{~N}=8)\end{array}$ & $\begin{array}{l}31 \\
(\mathrm{~N}=4)\end{array}$ & $\begin{array}{l}8 \\
(\mathrm{~N}=1)\end{array}$ & $\begin{array}{l}0 \\
(\mathrm{~N}=0)\end{array}$ \\
\hline $\begin{array}{l}\text { I feel a strong attachment toward } \\
\text { my own ethnic group. }\end{array}$ & $\begin{array}{l}69 \\
(\mathrm{~N}=9)\end{array}$ & $\begin{array}{l}23 \\
(\mathrm{~N}=3)\end{array}$ & $\begin{array}{l}8 \\
(\mathrm{~N}=1)\end{array}$ & $\begin{array}{l}0 \\
(\mathrm{~N}=0)\end{array}$ \\
\hline $\begin{array}{l}\text { I feel good about my cultural or } \\
\text { ethnic background. }\end{array}$ & $\begin{array}{l}92 \\
(\mathrm{~N}=12)\end{array}$ & $\begin{array}{l}8 \\
(\mathrm{~N}=1)\end{array}$ & $\begin{array}{l}0 \\
(\mathrm{~N}=0)\end{array}$ & $\begin{array}{l}0 \\
(\mathrm{~N}=0)\end{array}$ \\
\hline
\end{tabular}


Students were asked if they had a clear sense of their ethnic background and what it meant for them, ten students (77\%) reported that they strongly agreed with this statement, and three students (23\%) reported that they agreed with this statement (see Table 22).

Students were asked if they thought a lot about whether their lives will be affected by being a member of their ethnic group. Two students (15\%) responded that they strongly agreed that they do think a lot about it. Six students (46\%) responded that they agree that they think a lot about their ethnic group. Four students (31\%) responded that they disagreed that they thought a lot about they would be affected by being a member of their ethnic group, and one student (8\%) responded that he strongly disagreed that he thought about it at all (see Table 22).

When asked if they were happy that they were members of the groups they belong to, twelve students (92\%) strongly agreed that they were and one student (8\%0 agreed that he was happy about being a member of his group (see Table 22).

Students were asked if they had a strong sense of belonging to their own ethnic groups. Nine students (69\%) reported that they strongly agreed that they did. Four students (31\%) responded that they agreed that they had a strong sense of their belonging (see Table 22).

Students were asked if they understood what their ethnic group membership meant to them. Nine students (69\%) responded that they strongly agreed that they understood what membership in their ethnic group meant to them, and four students (31\%) responded that they agreed that they understood what their membership meant to them (see Table 22).

When asked if students had talked with others to learn more about their own ethnic group, six students (46\%) strongly agreed that they had. Five students (38\%) agreed that they had, and two students (15\%) responded that they disagreed that they had try to talk to others about their ethnic groups (see Table 22). 
When asked if students had pride in their ethnic groups, the majority of students (85\%) responded that they strongly agreed (see Table 22).

Students were asked if they participated in cultural practices of their own groups. including special foods, music, or customs. Eight students (62\%) responded that they strongly agreed that they participated in cultural practices. Four students (31\%) responded that they agreed that they participated in cultural practices, and one student (8\%) responded that she disagreed that she responded in cultural practices (see Table 22).

When questioned about having a strong attachment toward their own ethnic group, nine students (69\%) responded that they strongly agreed that they did. Three students (23\%) responded that they agreed that they had a strong attachment to their ethnic group, and one student (8\%) responded that he did not have a strong attachment to his ethnic group (see Table 22).

Students were asked if they felt good about their culture or ethnic background. Eleven students (92\%) responded that they strongly agreed that they felt good about their ethnic back ground and one student (8\%) responded that he disagreed that he felt good about his own ethnic group (see Table 22).

The next three questions on the MEIM required students to identify their ethnicity (see Table 23), their father's ethnicity (see Table 24), and their mother's ethnicity (see Table 25). Nine students (69\%) reported their ethnicity was Hispanic (see Table 23). Three students 23\%) reported their ethnicity as mixed with their parents being from two different groups. One student (8\%) wrote that he was mixed because his mother was Hispanic, but his father was half-Black and half-White (see Table 23). 
Table 23

Knowledge College Students’ Ethnicity

\begin{tabular}{llll}
\hline $\begin{array}{l}\text { Question } \\
13\end{array}$ & $\begin{array}{l}\text { Hispanic of } \\
\text { Hispanic, including } \\
\text { Mexican American, } \\
\text { Central American, } \\
\text { and others }\end{array}$ & $\begin{array}{l}\text { Mixed: } \\
\text { Parents } \\
\text { are from } \\
\text { two } \\
\text { different } \\
\text { groups }\end{array}$ & \\
\hline $\begin{array}{l}\text { My } \\
\text { ethnicity } \\
\text { is }\end{array}$ & 69 & 23 & 8 \\
& $(\mathrm{~N}=9)$ & $(\mathrm{N}=3)$ & $(\mathrm{N}=1)$ \\
\hline
\end{tabular}

With regard to their father's ethnicity, eleven students (85\%) reported that their fathers were Hispanic (see Table 24). Two students (15\%) reported that their father's were mixed from two different groups.

Table 24

Knowledge College Father's Ethnicity

\begin{tabular}{lll}
\hline $\begin{array}{l}\text { Question } \\
14\end{array}$ & $\begin{array}{l}\text { Hispanic of Hispanic, } \\
\text { including Mexican American, } \\
\text { Central American, and others }\end{array}$ & $\begin{array}{l}\text { Mixed: Parents are from } \\
\text { two different groups }\end{array}$ \\
\hline $\begin{array}{l}\text { My } \\
\text { father's } \\
\text { ethnicity }\end{array}$ & 85.0 & 15.0 \\
is & $(\mathrm{N}=11)$ & $(\mathrm{N}=2)$ \\
\hline
\end{tabular}

With regard to their mother's ethnicity, ten students (77\%) reported that their mother's were Hispanic (see Table 25). Two students (15\%) reported that their mothers were mixed from two different groups, and one student (8\%) reported that his mother had multiple types of ethnicity, but that she was half Hispanic. 
Table 25

Knowledge College Mother's Ethnicity

\begin{tabular}{llll}
\hline Question 15 & $\begin{array}{l}\text { Hispanic of Hispanic, } \\
\text { including Mexican } \\
\text { American, Central } \\
\text { American, and others }\end{array}$ & $\begin{array}{l}\text { Mixed: } \\
\text { Parents are } \\
\text { from two } \\
\text { different } \\
\text { groups }\end{array}$ & Other, Write in \\
\hline $\begin{array}{l}\text { My mother's } \\
\text { ethnicity is }\end{array}$ & 77.0 & 15.0 & 8.0 \\
& $(\mathrm{~N}=10)$ & $(\mathrm{N}=2)$ & $(\mathrm{N}=1)$ \\
\hline
\end{tabular}




\section{Chapter Five: Poor Folks College}

\section{Institutional Background}

Poor Folks College is a small college located in a rural setting. It has nearly 4000 students enrolled and offers a 17 to 1 student to instructor ratio. The college is a two-year public college that offers more than 50 associates degrees, over 15 certificates, and over 10 letters of recognition. The mission statement for Poor Folks College stated that it serves all surrounding communities, and that the college's focus is the preparation of individuals in mind, body, and spirit for lives of fulfillment, leadership, and service in a diverse and global society. The college mission statement emphasizes that the college is committed to engaging students in rich and challenging learning opportunities within a small college atmosphere that is known for its personal touch (Poor Folk website).

The college is located on 316 acres and includes 15 buildings. The buildings are very easy to find. Each building is identified with a huge sign that makes the campus easy to maneuver from building to building. Faculty are also extremely helpful when a person is trying to find a certain location. In fact, two of the faculty members helped this researcher locate a student and e-mail him to let him know that she was on campus to conduct an interview.

Poor Folks College is a mixed part-full time exclusively undergraduate medium two-year college (Poor Folks website). According to the college's website, the median family income in the city where the college is located is $\$ 30,970$. Poor Folks College participates in Title IV Federal Financial Aid Programs. Eighty-one percent of the students attending Poor Folks College are receiving financial aid (Poor Folks website). 
Poor Folks College has an open-admissions policy, but it does require students to take a placement test in reading and algebra. Students who do not pass these tests are required to take remedial classes. These classes do not count as credit courses.

Poor Folks College has 77 full-time tenured faculty. Thirty-six are male and 41 are female. It also employs 30 non-tenured, but tenure-track faculty. Eleven are male and 19 are female, and four faculty members are non-tenured track, one is male, and three are female (Poor Folks website).

\section{Study Participants}

Thirteen Hispanic students were interviewed at Poor Folks College in March of 2011. These students met individually with the researcher and answered questions from a protocol created by the researcher. After each interview, students were given the Multigroup Ethnic Identity Measure (MEIM) to determine how they rated themselves regarding their ethnicity. All students were provided information regarding confidentiality before completing the interviews and the MEIM. Students were once again informed that their identities would be kept anonymous. Pseudonyms for the participants and their respective colleges are used to maintain confidentiality throughout the discussion of emergent themes.

Table 26 shows demographic results of the thirteen students interviewed. Nine students (69\%) interviewed were females. Four students (31\%) were males. The ages of the students interviewed ranged from 18-35. Overall, eight students (62\%) were non-traditional students (see Table 26).

Eleven of the students (85\%) had earned over 22 credits, and two students (15\%) were unsure of how many credits they had earned (see Table 26). 
Table 26

\section{Demographics}

\begin{tabular}{|c|c|c|c|c|c|c|c|c|}
\hline Participant & Gender & Age & Credits & Major & GPA & $\begin{array}{l}\text { Ed. } \\
\text { Goal }\end{array}$ & Former Residence & $\begin{array}{l}\text { Present } \\
\text { Residence } \\
\end{array}$ \\
\hline 1 & $\mathrm{~F}$ & 19 & 36 & $\begin{array}{l}\text { Secondary } \\
\text { Education }\end{array}$ & 3.2 & Transfer & California & $\begin{array}{l}\text { With } \\
\text { Parents }\end{array}$ \\
\hline 2 & $\mathrm{~F}$ & 19 & 18 & $\begin{array}{l}\text { Pre-Human } \\
\text { Service }\end{array}$ & 3.0 & Transfer & $\mathrm{N} / \mathrm{A}$ & $\begin{array}{l}\text { With } \\
\text { Parents }\end{array}$ \\
\hline 3 & $\mathrm{~F}$ & 20 & 36 & $\begin{array}{l}\text { OT } \\
\text { Assistant }\end{array}$ & 3.5 & $2 Y$ & $\begin{array}{l}\text { Hometown with } \\
\text { parents }\end{array}$ & $\begin{array}{l}\text { House in } \\
\text { Town }\end{array}$ \\
\hline 4 & $\mathrm{~F}$ & 22 & $20+$ & $\begin{array}{l}\text { Criminal } \\
\text { Justice }\end{array}$ & 2.0 & $2 Y$ & $\begin{array}{l}\text { Hometown with } \\
\text { parents }\end{array}$ & $\begin{array}{l}\text { House in } \\
\text { Town }\end{array}$ \\
\hline 5 & $\mathrm{~F}$ & 29 & 36 & Nursing & 3.8 & $2 Y$ & N/A & Husband \\
\hline 6 & $\mathrm{~F}$ & 24 & 42 & Nursing & 3.5 & $2 Y$ & N/A & Husband \\
\hline 7 & $\mathrm{~F}$ & 19 & 36 & $\begin{array}{l}\text { Criminal } \\
\text { Justice }\end{array}$ & 2.7 & Transfer & $\mathrm{N} / \mathrm{A}$ & $\begin{array}{l}\text { Apartment } \\
\text { with } \\
\text { Family } \\
\end{array}$ \\
\hline 8 & $\mathrm{M}$ & 22 & 22 & $\begin{array}{l}\text { Computer } \\
\text { Science }\end{array}$ & 3.0 & $2 Y$ & $\mathrm{~N} / \mathrm{A}$ & $\begin{array}{l}\text { With } \\
\text { Parents }\end{array}$ \\
\hline 9 & $\mathrm{M}$ & 29 & $48+$ & $\begin{array}{l}\text { Computer } \\
\text { Science }\end{array}$ & 3.7 & $2 Y$ & N/A & $\begin{array}{l}\text { Apartment } \\
\text { with } \\
\text { Family } \\
\end{array}$ \\
\hline 10 & $\bar{M}$ & 24 & 36 & $\begin{array}{l}\text { Forest } \\
\text { Technology }\end{array}$ & 3.2 & $4 Y$ & $\mathrm{~N} / \mathrm{A}$ & $\begin{array}{l}\text { With } \\
\text { Parents }\end{array}$ \\
\hline 11 & $\mathrm{~F}$ & 18 & Unsure & $\begin{array}{l}\text { Physical } \\
\text { Therapist } \\
\text { Assistant } \\
\end{array}$ & 2.8 & Transfer & $\begin{array}{l}\text { New } \\
\text { York/Dominican } \\
\text { Republic }\end{array}$ & $\begin{array}{l}\text { Campus } \\
\text { Housing }\end{array}$ \\
\hline 12 & $\mathrm{~F}$ & 19 & Unsure & $\begin{array}{l}\text { Criminal } \\
\text { Justice }\end{array}$ & 2.5 & Transfer & Baltimore & $\begin{array}{l}\text { Campus } \\
\text { Housing }\end{array}$ \\
\hline 13 & $\mathrm{M}$ & 35 & 102 & $\begin{array}{l}\text { Business } \\
\text { Management }\end{array}$ & 2.8 & Transfer & New York & Apartment \\
\hline
\end{tabular}

Four students (31\%) interviewed were majoring in some type of medical field (see Table 26). Two students (15\%) were majoring in nursing, and the other two (15\%) were majoring in occupational and physical therapy assistant programs. Three students (23\%) were majoring in criminal justice and two students (15\%) were majoring in computer science. One student was majoring in business management. One student (8\%) was majoring in secondary education, one 
student (8\%) was majoring in pre-human services, and one student (8\%) was majoring in forest technology (see Table 26).

Students’ grade point averages ranged from 2.0 to 3.8. Seven students (54\%) reported that they will earn an associate's degree and will not continue toward a four-year degree (see Table 26). Five students (38\%) reported that they will transfer to a four-year college or university to complete their degrees (see Table 26).

After discussing demographics of age, major, GPA, and future plans, students were asked to describe the environment where they were raised. Twelve students (92\%) interviewed were born and raised in the United States (see Table 27). Marjorie Johnson, an 18-year-old physical therapy assistant major, was born in the Dominican Republic. Seven students (54\%) reported that they were raised in "normal” household environments. Seven students (54\%) reported that they were very close with their families. Six students (46\%) reported that they were raised in environments where money was a constant concern, and their parents were always worried about money and how to pay the bills (see Table 27). One student (8\%) commented that her mother died when she was young, so she was passed around to family members. An eighteen-year-oldstudent commented,

I actually was being raised by my mother. Typically, I was raised like a normal person. I was actually only with my mother. She raised us first, since we were babies to the age of 12. However, she got cancer, and then she died. Since then, I had to move to another city and live with my aunt. She was my guardian for three years, and then I moved with other family members. Then my dad had the passports and residence card to live in New York City, so he came and got us, and then we all moved to New York. That is where I lived until I came here. 
Table 27

Childhood Environments

\begin{tabular}{lcc}
\hline $\begin{array}{l}\text { Interview response: } \\
\begin{array}{l}\text { Describe the place where you } \\
\text { were raised }\end{array}\end{array}$ & $\begin{array}{c}\text { Number of } \\
\text { responses } \\
\mathrm{N}=33\end{array}$ & $\begin{array}{c}\text { \% based on } \\
\text { number of } \\
\text { respondents } \\
\mathrm{N}=13\end{array}$ \\
\hline Raised in the United States & 12 & 92 \\
\hline $\begin{array}{l}\text { Were close with their } \\
\text { families }\end{array}$ & 7 & 54 \\
\hline $\begin{array}{l}\text { Lived in a normal } \\
\text { environment }\end{array}$ & 7 & 54 \\
\hline $\begin{array}{l}\text { Lived in a low socio- } \\
\text { economic environments }\end{array}$ & 6 & 82 \\
\hline $\begin{array}{l}\text { Mother died when } \\
\text { interviewee was young }\end{array}$ & 1 & \\
\hline
\end{tabular}

Students were asked about their parents educational backgrounds (see Table 28). Ten students (77\%) reported that their parents had no education outside of high school, so obtaining jobs was very difficult, and their parents constantly struggled for work. Two students (15\%) reported that their fathers had attended some type of trade school. A twenty-two year-old criminal justice major student explained,

My parents live in Baltimore. My dad actually has a lot of experience with refrigerators and air conditioners and things like that. I know that he took some classes so that he could get certified so that he could make more money, but he never was able to pass the test. I think it was because of the reading.

One student (8\%) reported that he was almost positive that his mother attended college, but he was not sure if she ever graduated. This thirty-five-year-old business major explained,

I know that my mom attended college, but I am not sure where. I am not sure if she ever graduated. It was somewhere in New York, but I left home when I was 16, and I have never talked to her since. We lived in a really bad neighborhood in the Bronx, and I had 
to leave. The situation there was really bad, so I left. I came here because I had an aunt, but my mom was involved in some things, so I got out of the city, and I have never gone back.

Table 28

Parents’ Educational Backgrounds

\begin{tabular}{lcc}
\hline $\begin{array}{l}\text { Interview response: } \\
\text { Educational background of } \\
\text { parents }\end{array}$ & $\begin{array}{c}\text { Number of } \\
\text { responses } \\
\mathrm{N}=13\end{array}$ & $\begin{array}{c}\text { \% based on } \\
\text { number of } \\
\text { respondents } \\
\mathrm{N}=13\end{array}$ \\
\hline Did not attend college & 10 & 77 \\
\hline Attended trade school & 2 & 15 \\
\hline Possibly attended college & 1 & 8 \\
\hline
\end{tabular}

Students were asked about their decisions to attend college and who they thought was most instrumental in influencing them to attend college (see Table 29). Ten students (77\%) commented that their mothers were most influential in their decisions to attend college (see Table 29). A second-year criminal justice major explained, Mostly mom and her side of the family influenced me. A couple of my cousins have high school diplomas, but only a very few have college degrees, so they encouraged me to look into college. It was always a dream of mine to go to college. I just assumed after high school I would try to go to college. I really didn’t want to go to work after high school. I mean, like a job-job. I work part-time, I just don’t want that to be my real job. Another student explained,

Well, I think my dad got as far as middle school or maybe high school. I'm not sure, but I know that my mom didn't get hardly any education. She only got to the $1^{\text {st }}$ grade, so she really doesn't know that much about school or anything, but she knows because of 
other family members that I need to go to college. So, I guess I would say that she is the one who has influenced me the most because in a way, I guess she doesn't want me to end up like her, like with no education.

She cleans houses and hates it. She has always said that she wants me to live in a house like the ones she cleans.

One (8\%) student reported that her father was the main person in who life who influenced her to attend college. One student (8\%) reported that her guidance counselor was most influential in her attending college, and one student (8\%) reported that he influenced himself to attend college.

Table 29

Influences to Attend College

\begin{tabular}{lcc}
\hline $\begin{array}{l}\text { Interview response: } \\
\text { Influences to attend college }\end{array}$ & $\begin{array}{c}\text { Number of responses } \\
(\mathrm{N}=13)\end{array}$ & $\begin{array}{c}\text { \% based upon the number } \\
\text { of respondents } \\
(\mathrm{N}=13)\end{array}$ \\
\hline Mother & 10 & 77 \\
\hline Father & 1 & 8 \\
\hline Counselor & 1 & 8 \\
\hline Self & 1 & 8 \\
\hline
\end{tabular}

Students were asked about their families’ expectations now that they were attending college (see Table 30). Ten students (77\%) reported that their families expected them to graduate with a degree from Poor Folks College (see Table 30). This would be a two-year degree. An eighteen -year-old freshman explained,

My father is expecting me to pass college. They want me to have a degree, to have a good job in the next years. My father wants me to pass my major, so that I can make it in 
my life. Then I think he pretty much wants me to get married and have kids. However, they want me to always be by their side, to be with my people.

A twenty-four year-old forestry major commented,

They just want me to finish my degree here. They don't care if it is associates or bachelors; they just want me to get a degree. They want me to be happy. I think they will probably want me to live with them after I finish, but I don't know if I will do that. Two students (15\%) reported that their parents expected them to get a four-year degree. One student (8\%) reported that his family had no expectations for him to graduate.

Table 30

Family Expectations

\begin{tabular}{lcc}
\hline $\begin{array}{l}\text { Interview response: } \\
\text { Influences to attend college }\end{array}$ & $\begin{array}{c}\text { Number of responses } \\
(\mathrm{N}=12)\end{array}$ & $\begin{array}{c}\text { \% based upon the number } \\
\text { of respondents } \\
(\mathrm{N}=13)\end{array}$ \\
\hline Complete two-year degree & 10 & 77 \\
\hline Complete four-year degree & 2 & 15 \\
\hline
\end{tabular}

Students were questioned about why they chose to attend Poor Folks College. Nine students (69\%) said that they live close to the college, so it was easy for them to commute (see Table 31). Eight students (62\%) reported that they chose Poor Folks College because the tuition was affordable. A nineteen-year-old business major explained,

I don't have to live on campus here. I can live at home, so I don't have to pay housing or anything like that. Plus, my parents can afford what I have to pay after I get help from financial aid. My brother also works close by here, so he drops me off and then I pick him up after my classes. Sometimes I go to the library and do my work until he gets off work, so that helps me study too. 
Table 31

Decision to Attend Poor Folks College

\begin{tabular}{lcc}
\hline $\begin{array}{l}\text { Interview response: } \\
\text { Why students chose } \\
\text { Knowledge }\end{array}$ & $\begin{array}{c}\text { Number of responses } \\
(\mathrm{N}=20)\end{array}$ & $\begin{array}{c}\text { \% based upon the number } \\
\text { of respondents } \\
(\mathrm{N}=13)\end{array}$ \\
\hline Close proximity to home & 9 & 69 \\
\hline Affordable tuition & 8 & 62 \\
\hline Programs that were offered & 3 & 23 \\
\hline
\end{tabular}

A twenty-two- year- old computer science major commented,

I went to high school here and really didn’t apply myself in high school. I really didn’t have any goals, so I just hung out with my parents. But that got old, so I decided to go to college, and this is the one that is closest for me. I mean I can still live at home and don't have to pay for a dorm or an apartment. That's why I came here.

A nineteen -year-old human services major commented,

I chose to come here because it is near my family. We are really a close family. We are always with each other. My grandmother lives with us, and we do everything together. I do not want to go away from them, so this is the closest place I could go and still live with my family. Also, I mean, my parents have money for me to attend college, like not a lot, but enough, and so this was a good place for me to go because it is affordable for my family.

Three students (23\%) said that they attended Poor Folks because of programs that it offered (see Table 31). One student explained this by commenting,

It was during a search that I did on collegeboard.com. It was one of the colleges that did have the physical therapist program because there were only a few where I live, and there 
were others that were outside the city too. I did apply to them, but I didn't get the acceptance letter in time. I didn’t have any choice to come here all the way here to Maryland. So it was my only choice.

A twenty-year- old occupational therapy major commented, I came up here with my high school. We had a tour or something like that, and I liked the setting and atmosphere. I had never been here. I didn’t even know about Poor Folks before because I live all the way in Catskills County. I like the place, that is was a different place, far away from where I live. I just wanted to explore and get to know other places. When I saw that they had an OT program here, it was basically an easy decision.

Students were questioned about challenges they encountered while making decisions to attend Poor Folks College (see Table 32). Nine students (69\%) reported that they did not have any challenges trying to decide to attend this college because it was so close to home, and so it was an easy decision. Seven students (54\%) reported that finances were a concern and a constant challenge while they were attending college. Six students (46\%) reported that they knew that they would be accepted to Poor Folks; however, they did not pass the assessment tests and had to take remedial classes. Four students (31\%) reported that they had financial difficulties, so Poor Folks was the decision that they had to make (see Table 32). One twentyfour year-old student commented that she was torn between this college and one other, but she explained that Poor Folks College was more fitting to her financial needs, so she chose Poor Folks College. Another student explained, 
Well, one of the major reasons that I am here is the financial situation. So, basically, since my family (well, we are not poor), but you know we have financial struggles just like every single Hispanic family in my city, where we are living is one [reason]. The other reason is racism. I don't see it here, and I am friends with both Black people and White people here. However, it is noticeable where I live. We have our community, and we really don't go outside of it. You know that it is different. I can't explain it. But here, when you get into your classes, and we have to do projects; we just work together. I’m sorry, I can't explain it. It's just that there is not racism stuff here. Not that I see anyway.

Table 32

Challenges Students Encountered

\begin{tabular}{lcc}
\hline $\begin{array}{l}\text { Interview response: } \\
\text { Challenges students have } \\
\text { encountered }\end{array}$ & $\begin{array}{c}\text { Number of responses } \\
(\mathrm{N}=19)\end{array}$ & $\begin{array}{c}\text { \% based upon the number } \\
\text { of respondents } \\
(\mathrm{N}=13)\end{array}$ \\
\hline $\begin{array}{l}\text { No Challenges due to } \\
\text { proximity }\end{array}$ & 9 & 69 \\
\hline Finances & 7 & 54 \\
\hline Remedial Courses & 6 & 46 \\
\hline
\end{tabular}

Students were asked how their high schools provided supports or if any programs existed that helped them decide to go to college (see Table 33). Seven students (54\%) responded that they received help when they were in high school. Students responded that they received assistance from their guidance counselors and had help completed necessary paperwork. An eighteen -year-old education major commented,

The people who work at the high school I was in said it was one of the bad high schools that our city has because there is so much violence and stuff. However, it is now four 
schools in one, so it is even worse because of all of the different kinds of people. The people in my high school did help me a lot because they did not want me to stay in that area. Some of the people were my friends because I actually worked for them outside of school, so I think that that is why they helped me even more.

They are the ones who guided me on how to apply. They guided me on writing essays for the colleges and they helped me learn about financial aid. I think that probably without them, I would not be here.

Table 33

Programs and Support in High School

\begin{tabular}{lcc}
\hline $\begin{array}{l}\text { Interview response: } \\
\text { What types of support did } \\
\text { you receive in high school? }\end{array}$ & $\begin{array}{c}\text { Number of responses } \\
(\mathrm{N}=18)\end{array}$ & $\begin{array}{c}\text { \% based upon the number } \\
\text { of respondents } \\
(\mathrm{N}=13)\end{array}$ \\
\hline $\begin{array}{l}\text { Were supported in High } \\
\text { School }\end{array}$ & 7 & 54 \\
\hline $\begin{array}{l}\text { Did not receive support in } \\
\text { high School }\end{array}$ & 6 & 46 \\
\hline $\begin{array}{l}\text { Saw flyers around their high } \\
\text { schools }\end{array}$ & 4 & 81 \\
\hline Tour & 1 & 8 \\
\hline
\end{tabular}

Six students (46\%) reported that they did not receive any type of help to attend college when they were in high school (see Table 33).. Four students (31\%) stated that they saw flyers around school, but did not necessarily have anyone work with them individually (see Table 33). Nineteen year-old human services major reported,

That is a hard question. I went to two high schools. In the middle of $10^{\text {th }}$ grade, I moved to Pennsylvania, but they don’t really do programs. Basically they hand out papers and stuff that say there is going to be an open-house here and an open- house there, but I 
don't think that they ever really did any programs, and I know that no one ever talked to me specifically.

One student (8\%) reported that she made the decision to attend Poor Folks College because she came to visit the college when she was in high school (see Table 33). This criminal justice major commented,

I came up here with my high school. We had a tour or something like that, and I like the setting or atmosphere. I had never been, and I didn’t even know about Poor Folks College before because I live three hours away. I like the place. I liked that it was a different place-far from where I live. I just wanted to explore and get to know other places.

Students were asked if they were receiving any type of loan or grant to help them afford college (see Table 34). Twelve students (92\%) reported that they are currently receiving loans, grants, and/or financial aid to attend college. Of these 12 students, 9 students (75\%) reported that they were or had received Pell grants. Three students (23\%) were not sure what type of financial aid they were receiving. Human services major reported,

Yes, I know that I am, but I don't know what it is. I think it is called a PELL or something like that, but I am not sure. My father filled out all of the paperwork for me. He was aware of these forms, so he did it.

A nineteen year-old physical therapy major commented, I am receiving from the federal government, the PELL grant. Loans and basically for me, that's it. I am receiving those two financial aids. I mean there are three, but two of them are loans, and one of them is the grant. I was supposed to receive more than that. I was supposed to receive the Federal Work Study, the opportunity grant. However, I don't 
know what happened that they say they didn’t have enough money, so basically I didn’t have it.

One student (8\%) reported that he was not receiving any type of financial aid, but he was actually not sure whether he was or not. This computer science major commented, No, at least I don't think so. I am the oldest of seven kids, so you would think that I would be getting something. Maybe I just didn’t pay attention. I don’t know. I will probably try to see if I can get something next year. I'm not really much of a social person, though, so I probably won’t go ask anybody.

Table 34

Receiving Financial Aid

\begin{tabular}{lcc}
\hline $\begin{array}{l}\text { Interview response: } \\
\text { Are you currently receiving } \\
\text { financial aid? }\end{array}$ & $\begin{array}{c}\text { Number of responses } \\
(\mathrm{N}=22)\end{array}$ & $\begin{array}{c}\text { \% based upon the number } \\
\text { of respondents } \\
(\mathrm{N}=13)\end{array}$ \\
\hline $\begin{array}{l}\text { Currently receiving } \\
\text { financial aid }\end{array}$ & 12 & 92 \\
\hline Receiving Pell grants & 9 & 75 \\
\hline $\begin{array}{l}\text { Are not currently receiving } \\
\text { financial aid }\end{array}$ & 1 & 8 \\
\hline
\end{tabular}

Students were asked about what college resources they used while they were attending Poor Folks College (see Table 35). Seven students (54\%) reported that they use the labs and the library almost daily. A nineteen year-old occupational therapists major commented,

Well, I don’t have a computer at home, so I use the library and computer lab almost daily. That is why it was a good time for me to meet you today. I have three hours between my classes, so I always come here and use this time to work. I also use the writing lab. You can take your paper and they will go over it for you. I mean they will find the 
grammatical mistakes and help you fix them before you have to turn your paper in to your professor.

A twenty-two year old computer science major explained,

I come to the library all of the time. With all of the noise at my house, it is so hard to concentrate. Plus, everyone is fighting over the computer, so I just come here, put my headphones on, and use one of the computers. No one bothers you here.

A nineteen-year-old human services major commented,

I use the library all of the time. My grandmother lives with us, and she only speaks Spanish, so there will be all kinds of conversations going on in my house. Half will be in Spanish, and half will be in English. I mean I like all of the people, it is just so difficult when you are trying to study. Plus, my grandmother is always asking me what I am doing, and it takes me so long to try to explain it to her.

Table 35

Services Used

\begin{tabular}{lcc}
\hline $\begin{array}{l}\text { Interview response: } \\
\text { What college resources do } \\
\text { you use? }\end{array}$ & $\begin{array}{c}\text { Number of responses } \\
(\mathrm{N}=16)\end{array}$ & $\begin{array}{c}\text { \% based upon the number } \\
\text { of respondents } \\
(\mathrm{N}=13)\end{array}$ \\
\hline Library & 7 & 54 \\
\hline Writing lab & 5 & 38 \\
\hline Tutoring services & 4 & 31 \\
\hline
\end{tabular}

Five students (38\%) reported that they use the writing lab because they can have their papers graded before they give them to their professors for a classroom grade (see Table 35). Four students (31\%) reported that they use the tutoring services provided by the school. A secondary education major commented, 
When I first got here, I didn't use the tutoring. I thought that I could make it on my own, and then my instructor, he told me, "No, you have to go to tutoring. You will be so much better off. You can get someone to go over your work.”

After that, I started going to tutoring and my grades improved in his class, so then I started to go to tutoring for all of my classes. Now I am passing all of my classes and I really like it here.

Students were asked how socially connected they felt to the college (see Table 36).

Twelve students (92\%) responded that the faculty they have are very supportive and help them in their classes. A criminal justice major explained,

When I first got here, I didn’t use the tutoring. I thought that I could make it on my own, and then my instructor told me, “No, you have to go to tutoring. You will be so much better off. You can get someone to go over your work.”

After that, I started going to tutoring and my grades improved in his class, so then I started to go to tutoring for all of my classes. Now I am passing all of my classes and really like it here.

Eleven students (85\%) reported that they did not feel socially connected to a Hispanic population at Poor Folks College (see Table 36). Eight students (62\%) responded that they currently did not feel socially connected to the college because they lived at home and only came to the campus for their classes (see Table 36). Five students (38\%) responded that although they did not feel socially connected to the college, they felt that they had made friends from their classes and had fun working on group projects. A secondary education major Sam Cogar stated, I don’t really feel like I have a lot of friends here necessarily from my social group, but I work so much that I don’t have time for friendships anyway. I have had assignments 
where some of us are assigned a group project and we have to meet in the library to do it. I like that and have fun working with people, but I feel bad sometimes because people have to work around my work schedule.

Table 36

Socially Connected

\begin{tabular}{lcc}
\hline $\begin{array}{l}\text { Interview response: } \\
\begin{array}{l}\text { How socially connected do } \\
\text { students feel with students } \\
\text { and faculty? }\end{array}\end{array}$ & $\begin{array}{c}\text { Number of responses } \\
(\mathrm{N}=36)\end{array}$ & $\begin{array}{c}\text { \% based upon the number } \\
\text { of respondents } \\
(\mathrm{N}=13)\end{array}$ \\
\hline $\begin{array}{l}\text { Feel socially connected } \\
\text { with the faculty }\end{array}$ & 12 & 92 \\
\hline $\begin{array}{l}\text { Do not feel socially } \\
\text { connected with Hispanic } \\
\text { students }\end{array}$ & 11 & 62 \\
\hline $\begin{array}{l}\text { Do not feel socially } \\
\text { connected with students }\end{array}$ & 8 & 38 \\
\hline $\begin{array}{l}\text { Feel socially connected } \\
\text { with students when } \\
\text { assigned projects }\end{array}$ & 5 & \\
\hline
\end{tabular}

Students were asked if they belonged to any clubs or campus organizations. Students’ responses varied (see Table 37). Although seven students (54\%) acknowledged that clubs did exist on the campus, they reported that they were not actively engaged in them. For example, students commented that they had seen signs and banners on campus, but they were not really sure if they would qualify for that specific club. Students discussed that they were not aware of any type of clubs that existed for minority or groups based on ethnicity. Three students (23\%) commented that they were in clubs that were associated with the degrees they were working toward, but were not really sure exactly what the clubs did. A twenty-two year old Anne Marker explained,

I am aware of SOTO. That is the club where I belong. It is for the degree that I am getting. However, I do not know if there are any clubs that are for Hispanic students or 
for even minorities. I see a lot of Black students on campus, but I don't even think there is, you know, like an African American Club or anything like that.

Ironically, when this student was asked what SOTO meant or represented, she was unable to answer. She informed the researcher that she didn’t know, but she knew that it has something to do with her degree.

Table 37

Club Participation

\begin{tabular}{lcc}
\hline $\begin{array}{l}\text { Interview response: } \\
\text { Awareness of Clubs on } \\
\text { Campus }\end{array}$ & $\begin{array}{c}\text { Number of responses } \\
(\mathrm{N}=13)\end{array}$ & $\begin{array}{c}\text { \% based upon the number } \\
\text { of respondents } \\
(\mathrm{N}=13)\end{array}$ \\
\hline $\begin{array}{l}\text { Aware but do not } \\
\text { participate }\end{array}$ & 7 & 54 \\
\hline Participate in clubs & 3 & 23 \\
\hline Are not aware of any clubs & 3 & 23
\end{tabular}

Three students (23\%) reported that they were not aware of any clubs that existed on campus (see Table 37). However, twenty-year old Zachary Alt commented,

No, I don't know of any clubs. Well, I guess I shouldn't say that. I'm not really a social person, so I guess I haven’t really looked. I am sure that there are, but I probably wouldn’t participate in them anyway. I have to work all the time, so for me, that is something that is more high school than college.

I guess I could meet more people, but I don’t really have time for them anyway, so I don't know, I guess there are [clubs].

Students were asked if they enjoyed their classes since they enrolled in Poor Folks College and how they felt their instructors cared about their classes (see Table 38). Twelve 
students (92\%) responded that they enjoyed their classes. A computer science major, Cole Marker commented,

I really enjoy all of my classes here. I have to work, but there are so many people here to help you. I like that there aren’t a lot of people in my classes, so I have gotten to know most of the people in my classes. We do a lot of group work and have some study groups, so I really like it a lot.

Table 38

Classes at Poor Folks

\begin{tabular}{lcc}
\hline $\begin{array}{l}\text { Interview response: } \\
\text { How students feel about } \\
\text { their classes }\end{array}$ & $\begin{array}{c}\text { Number of responses } \\
(\mathrm{N}=22)\end{array}$ & $\begin{array}{c}\text { \% based upon the number } \\
\text { of respondents } \\
(\mathrm{N}=13)\end{array}$ \\
\hline Enjoy classes & 12 & 92 \\
\hline $\begin{array}{l}\text { Feel that professors care } \\
\text { about their progress }\end{array}$ & 9 & 69 \\
\hline Do not enjoy classes & 1 & 8 \\
\hline
\end{tabular}

Nine students (69\%) reported that they felt that they instructors cared about their progress. A secondary education major explained, I think that they professors really do care about my progress. Dr. Smith [this researcher had gotten this student from Dr. Smith's class] she makes everything very calm. I have to take this math class with her, and I am not very good at math. Aye, it is so frustrating to me, but when I come here, the class is so small and the people are so nice, it doesn't scare me. Yes, I think she cares a lot about my progress.

One student (8\%) reported that he did not enjoy his classes (see Table 38). When asked for reasons, this researcher learned that this student did actually like his instructors; he just did not want to have to go to school in general. This student commented, 
Oh, I guess I like all of my professors. I just have never really liked school. I’m not really sure what I want to do, so my parents pretty much told me that I had to go to school or they were pretty much going to cut me off [financially].

Students were asked if they had experienced any obstacles while attending Poor Folks College (see Table 39). Seven students (54\%) reported that the lack of money was a concern, so they had to work. Four students (31\%) responded that working and attending school were difficult at times, especially when they were working in groups with other students. One student (8\%) reported that she had an experience with one of the students who lived near her, but ironically, that student had gotten in trouble on campus and was forced to leave the campus and consequently move.

Table 39

Obstacles at Poor Folks College

\begin{tabular}{lcc}
\hline $\begin{array}{l}\text { Interview response: } \\
\begin{array}{l}\text { Obstacles students } \\
\text { encountered at Poor Folks } \\
\text { College }\end{array}\end{array}$ & $\begin{array}{c}\text { Number of responses } \\
(\mathrm{N}=12)\end{array}$ & $\begin{array}{c}\text { \% based upon the number } \\
\text { of respondents } \\
(\mathrm{N}=13)\end{array}$ \\
\hline Finances & 7 & 54 \\
\hline $\begin{array}{l}\text { Scheduling work with } \\
\text { school }\end{array}$ & 4 & 31 \\
\hline Bully & 1 & 8 \\
\hline
\end{tabular}

Students were asked what they would like to teach people at Poor Folks about their culture (see Table 40). Nine students (69\%) responded that they would teach people about the food. Four students (31\%) responded that they would like to teach people that a lot of the stereotypes that exist are not true. Three students (23\%) responded that they wished that they knew more about their cultures so they could teach others (see Table 40). Computer science major, Brian Sisk commented, 
Well, I know the food is good. I really wish I would have spent more time researching our background and speaking with my grandparents and my father concerning our culture, so I can convey what my ethnic background means to me, but unfortunately I haven't. Sure, I would love to visit [Columbia] so that I could teach people more about my culture. I have heard it is beautiful and that is about it.

Table 40

Education of Culture

\begin{tabular}{lcc}
\hline $\begin{array}{l}\text { Interview response: } \\
\text { What students would teach } \\
\text { others about their culture }\end{array}$ & $\begin{array}{c}\text { Number of responses } \\
(\mathrm{N}=16)\end{array}$ & $\begin{array}{c}\text { \% based upon the number } \\
\text { of respondents } \\
(\mathrm{N}=13)\end{array}$ \\
\hline Foods & 9 & 69 \\
\hline Awareness of stereotypes & 4 & 31 \\
\hline $\begin{array}{l}\text { Wish they had more time to } \\
\text { explore their own culture }\end{array}$ & 3 & 23 \\
\hline
\end{tabular}

Eighteen- year-old Greg Davis responded,

I think that I would want people to know that I do not speak Spanish to offend them. Sometimes, we [my family] try not to [speak Spanish] because we think it offends other people and other people believe that we are talking about them, and we don't want other people to think that we are talking about them because we are actually focusing on something else. We would like to have respect and show respect, so whenever we are in the stores and are talking, people aren't offended by our language. I mean here it is a little different because there are a lot of nationalities and most Americans, they basically know they are speaking to each other about something, but not about me. There it is different, it is oh, they must be talking about me and really we are not. I would like to teach people that. 
Nineteen -year-old Angela Dean discussed,

I guess I was raised in a White environment. We didn’t speak Spanish in my household. My dad didn’t want to teach my mother, so he didn't teach us - that is what he tells us. I mean I wish he would have. I guess I would just teach them the different things that I learned when I was younger that my grandmother taught me about our culture. Just different foods and recipes and things like that. I have always wanted to go to where our family is from, which is Guatemala. I haven't been able to do that. My brother has.

Students were asked if they thought about whether being Hispanic currently affected their lives (see Table 41). Ten students (77\%) reported that they did not feel that being Hispanic affects their lives right now. Two students (15\%) reported that they thought that being Hispanic did affect their lives right now. A nineteen-year- old human services major commented, I don’t know if you could say that it affects my life in like making it easier or more difficult, but it definitely affects my life with how I feel about my heritage. I am very proud of my heritage and my family. We are very close, and I couldn’t imagine it any other way. I like being around all of the people.

Table 41

Affects of Being Hispanic

\begin{tabular}{lcc}
\hline $\begin{array}{l}\text { Interview response: } \\
\text { Does ethnicity } \\
\text { affect lives right now }\end{array}$ & $\begin{array}{c}\text { Number of responses } \\
(\mathrm{N}=12)\end{array}$ & $\begin{array}{c}\text { \% based upon the number } \\
\text { of respondents } \\
(\mathrm{N}=13)\end{array}$ \\
\hline $\begin{array}{l}\text { Does not affect life right } \\
\text { now }\end{array}$ & 10 & 77 \\
\hline Affects life right now & 2 & 15 \\
\hline
\end{tabular}

Students were asked if they had encountered any experiences which made them more aware of their ethnic background (see Table 42). Students' responses varied. Eight students 
(62\%) reported that they had encountered experiences where they were treated differently because they were Hispanic. These responses varied from where students discussed how people looked at them when they spoke in Spanish to students feeling that they were mistreated outside of the college environment because of their ethnicity. An eighteen-year-old undecided major commented,

Being Hispanic and moving to another place, different society actually makes it hard because you are learning a different language, different cultures, and a different way of life. This is very different from what I was used to living in the Dominican Republic, so pretty much it is mostly harder than easier.

Five students responded that they had not noticed any type of awareness since they have entered college. A business major explained,

I don't think it is any type of awareness that you have because you are in college. I think it is an awareness you have because you have always been made to be aware. I really haven’t paid that much attention to being different it's kind of like you just are and depending on where you are, you may act differently. When I am at home with my family and other Hispanic people, we tend to be louder than what I am in most places, but I don’t really think of it as awareness, it is just the way it is. 
Table 42

Ethnicity Awareness

\begin{tabular}{lcc}
\hline $\begin{array}{l}\text { Interview response: } \\
\text { Awareness of ethnicity. }\end{array}$ & $\begin{array}{c}\text { Number of responses } \\
(\mathrm{N}=15)\end{array}$ & $\begin{array}{c}\text { \% based upon the number } \\
\text { of respondents } \\
(\mathrm{N}=13)\end{array}$ \\
\hline $\begin{array}{l}\text { Treated differently because } \\
\text { of Ethnicity }\end{array}$ & 8 & 62 \\
\hline $\begin{array}{l}\text { Have not noticed any kind } \\
\text { of awareness }\end{array}$ & 5 & 38 \\
\hline $\begin{array}{l}\text { Encountered positive } \\
\text { experiences }\end{array}$ & 2 & 15 \\
\hline
\end{tabular}

Two students (15\%) commented that although they had encountered experiences, they were not necessarily negative. A nursing student commented,

I used to live up there on campus housing. At the school, I don't see many Hispanic people, so you know when I was up there, it was "that Spanish girl over there." That is pretty much it. Other than that, I have really not had any other experiences that made me aware of my ethnicity. It is kind of funny because where I am from, there are so many Hispanics that I have never been called "that Spanish girl” before.

After these set of questions, students were asked about their success in college and when they expected to graduate. Furthermore, students were asked if they would remain in college for consecutive semesters until the completed their degrees. Thirteen of the students (100\%) reported that they would remain in college until they graduated. One student discussed that returning consecutively would be difficult because of money, but that she didn't want to quit because she was afraid that she would not return.

\section{Multigroup Ethnic Identity Measure}

Next, the researcher asked students to complete Jean Phinney’s Model of Ethnic Identity. This researcher believes that ethnic identity is essential to the development of a positive self- 
concept for minority students. It helps students by developing from a shared culture, religion, geography, and language and connects by a strong loyalty and kinship.

Phinney’s Model (1999) discussed two stages (factors) for students. Ethnic Identify Search (questions 1, 2, 3, 4, 8, and 10) and Affirmation, Belonging, and Commitment (questions 3, 5, 6, 7, 9, 11, 12). Questions 13, 14, and 15 are identification and categorization demographic questions. The MEIM questions are scored on a Likert-type scale with scores of 1-4 possible. The Mean of the Ethnic Identity Search questions tells far into identify search a person is, and the mean of the Affirmation, Belonging, and Commitment questions scores gauge how affirmed a person is in his or her ethnicity.

\section{Multigroup Ethnic Identity Measure Results}

After students were interviewed, each student was given the MEIM to determine how he or she felt about his or her ethnicity. Using Likert Scale responses, students identified how they felt about themselves individually and as a group. Table 43 discusses the results of each student responses.

When asked about whether students have spent time to learn more about their ethnic group and its history, traditions, and customs, eight students (62\%) reported that they strongly agreed, four students (31\%) agreed, and one student (8\%) disagreed that they had done this (see Table 43). 
Table 43

Poor Folks MEIM Responses

\begin{tabular}{|c|c|c|c|c|}
\hline Item & $\begin{array}{l}4 \\
\text { SA } \\
\text { \% based on the } \\
\text { number of } \\
\text { responses } \\
(\mathrm{N}=13)\end{array}$ & $\begin{array}{l}3 \\
\text { A } \\
\% \text { based on } \\
\text { the number } \\
\text { of responses } \\
(\mathrm{N}=13)\end{array}$ & $\begin{array}{l}2 \\
\mathrm{D} \\
\% \text { based on } \\
\text { the number } \\
\text { of responses } \\
(\mathrm{N}=13)\end{array}$ & $\begin{array}{l}1 \\
\text { SD } \\
\% \text { based on } \\
\text { the number } \\
\text { of responses } \\
(\mathrm{N}=13)\end{array}$ \\
\hline $\begin{array}{l}\text { I have spent time trying to find out } \\
\text { more about my ethnic groups such } \\
\text { as its history, traditions, and } \\
\text { custom. }\end{array}$ & $\begin{array}{l}62 \\
(\mathrm{~N}=8)\end{array}$ & $\begin{array}{l}31 \\
(\mathrm{~N}=4)\end{array}$ & $\begin{array}{l}8 \\
(\mathrm{~N}=1)\end{array}$ & $\begin{array}{l}0 \\
(\mathrm{~N}=0)\end{array}$ \\
\hline $\begin{array}{l}\text { I am active in organizations or } \\
\text { social groups that include mostly } \\
\text { members of my own ethnic groups. }\end{array}$ & $\begin{array}{l}62 \\
(\mathrm{~N}=8)\end{array}$ & $\begin{array}{l}31 \\
(\mathrm{~N}=4)\end{array}$ & $\begin{array}{l}8 \\
(\mathrm{~N}=1)\end{array}$ & $\begin{array}{l}0 \\
(\mathrm{~N}=0)\end{array}$ \\
\hline $\begin{array}{l}\text { I have a clear sense of my ethnic } \\
\text { background and what it means for } \\
\text { me. }\end{array}$ & $\begin{array}{l}69 \\
(\mathrm{~N}=9)\end{array}$ & $\begin{array}{l}31 \\
(\mathrm{~N}=4)\end{array}$ & $\begin{array}{l}0 \\
(\mathrm{~N}=0)\end{array}$ & $\begin{array}{l}0 \\
(\mathrm{~N}=0)\end{array}$ \\
\hline $\begin{array}{l}\text { I think a lot about how my life will } \\
\text { be affected by my ethnic group } \\
\text { membership. }\end{array}$ & $\begin{array}{l}15 \\
(\mathrm{~N}=2)\end{array}$ & $\begin{array}{l}77 \\
(\mathrm{~N}=10)\end{array}$ & $\begin{array}{l}8 \\
(\mathrm{~N}=1)\end{array}$ & $\begin{array}{l}0 \\
(\mathrm{~N}=0)\end{array}$ \\
\hline $\begin{array}{l}\text { I am happy that I am a member of } \\
\text { the group I belong to. }\end{array}$ & $\begin{array}{l}85 \\
(\mathrm{~N}=11)\end{array}$ & $\begin{array}{l}15 \\
(\mathrm{~N}=2)\end{array}$ & $\begin{array}{l}0 \\
(\mathrm{~N}=0)\end{array}$ & $\begin{array}{l}0 \\
(\mathrm{~N}=0)\end{array}$ \\
\hline $\begin{array}{l}\text { I have a strong sense of belonging } \\
\text { to my own ethnic group. }\end{array}$ & $\begin{array}{l}77 \\
(\mathrm{~N}=10)\end{array}$ & $\begin{array}{l}15 \\
(\mathrm{~N}=2)\end{array}$ & $(\mathrm{N}=1)$ & $(\mathrm{N}=0)$ \\
\hline $\begin{array}{l}\text { I understand pretty well what my } \\
\text { ethnic group membership means to } \\
\text { me. }\end{array}$ & $\begin{array}{l}62 \\
(\mathrm{~N}=8)\end{array}$ & $\begin{array}{l}38 \\
(\mathrm{~N}=5)\end{array}$ & $\begin{array}{l}0 \\
(\mathrm{~N}=0)\end{array}$ & $\begin{array}{l}0 \\
(\mathrm{~N}=0)\end{array}$ \\
\hline $\begin{array}{l}\text { In order to learn more about my } \\
\text { ethnic background, I have often } \\
\text { talked to other people about my } \\
\text { ethnic group. }\end{array}$ & $\begin{array}{l}54 \\
(\mathrm{~N}=7)\end{array}$ & $\begin{array}{l}38 \\
(\mathrm{~N}=5)\end{array}$ & $\begin{array}{l}8 \\
(\mathrm{~N}=1)\end{array}$ & $\begin{array}{l}0 \\
(\mathrm{~N}=0)\end{array}$ \\
\hline $\begin{array}{l}\text { I have a lot of pride in my ethnic } \\
\text { group. }\end{array}$ & $\begin{array}{l}92 \\
(\mathrm{~N}=12)\end{array}$ & $\begin{array}{l}8 \\
(\mathrm{~N}=1)\end{array}$ & $\begin{array}{l}0 \\
(\mathrm{~N}=0)\end{array}$ & $\begin{array}{l}0 \\
(\mathrm{~N}=0)\end{array}$ \\
\hline $\begin{array}{l}\text { I participate in cultural practices of } \\
\text { my own groups, such as special } \\
\text { food, music or customs. }\end{array}$ & $\begin{array}{l}69 \\
(\mathrm{~N}=9)\end{array}$ & $\begin{array}{l}23 \\
(\mathrm{~N}=3)\end{array}$ & $\begin{array}{l}8 \\
(\mathrm{~N}=1)\end{array}$ & $(\mathrm{N}=0)$ \\
\hline $\begin{array}{l}\text { I feel a strong attachment toward } \\
\text { my own ethnic group. }\end{array}$ & $\begin{array}{l}77 \\
(\mathrm{~N}=10)\end{array}$ & $\begin{array}{l}15 \\
(\mathrm{~N}=2)\end{array}$ & $\begin{array}{l}8 \\
(\mathrm{~N}=1)\end{array}$ & $\begin{array}{l}0 \\
(\mathrm{~N}=0)\end{array}$ \\
\hline $\begin{array}{l}\text { I feel good about my cultural or } \\
\text { ethnic background. }\end{array}$ & $\begin{array}{l}85 \\
(\mathrm{~N}=11)\end{array}$ & $\begin{array}{l}15 \\
(\mathrm{~N}=2)\end{array}$ & $\begin{array}{l}0 \\
(\mathrm{~N}=0)\end{array}$ & $\begin{array}{l}0 \\
(\mathrm{~N}=0)\end{array}$ \\
\hline
\end{tabular}


When asked if students were active in organizing social groups that included mostly members of their own ethnic group, eight students (62\%) strongly agreed that they had. Four students (31\%) agreed that they had, and one student (8\%) disagreed (see Table 43).

Students were asked if they had a clear sense of their ethnic background and what it meant for them, nine students (69\%) reported that they strongly agreed with this statement, and four students (31\%) reported that they agreed with this statement (see Table 43).

Students were asked if they thought a lot about whether their lives will be affected by being a member of their ethnic group. Two students (15\%) responded that they strongly agreed that they do think a lot about it. Ten students (77\%) responded that they disagreed that they think a lot about their ethnic group. One student (8\%) responded that he strongly disagreed that that he thought a lot about how he would be affected by being a member of their ethnic group. (see Table 43).

When asked if they were happy that they were members of the groups they belong to, eleven students (85\%) strongly agreed that they were and two students (15\%) agreed that he was happy about being a member of his group (see Table 43).

Students were asked if they had a strong sense of belonging to their own ethnic groups (see Table 43). Ten students (77\%) reported that they strongly agreed that they did. Two students (15\%) responded that they agreed that they had a strong sense of their belonging to their ethnic group. One student (8\%) responded that he disagreed that he had a strong sense of belonging to his ethnic group (see Table 43).

Students were asked if they understood what their ethnic group membership meant to them. Eight students (62\%) responded that they strongly agreed that they understood what 
membership in their ethnic group meant to them. Five students (38\%) responded that they agreed that they understood what their membership meant to them. (see Table 43).

When asked if students had talked with others to learn more about their own ethnic group, seven students (54\%) strongly agreed that they had. Five students (38\%) agreed that they had, and one student (8\%) responded that he disagreed that he had tried to talk to others about their ethnic groups (see Table 43).

When asked if students had pride in their ethnic groups, 12 students (92\%) responded that they strongly agreed (see Table 43). One student (8\%) responded that he strongly agreed that he had pride in his ethnic group.

Students were asked if they participated in cultural practices of their own groups which include special foods, music, or customs. Nine students (69\%) responded that they strongly agreed that they participated in cultural practices (see Table 43). Three students (23\%) responded that they agreed that they participated in cultural practices, and 2 students (15\%) responded that they disagreed that she responded in cultural practices (see Table 43).

When questioned about having a strong attachment toward their own ethnic group, ten students (77\%) responded that they strongly agreed that they did. Two students (15\%) responded that they agreed that they had a strong attachment to their ethnic group, and one student (8\%) responded that he did not have a strong attachment to his ethnic group (see Table 43).

Students were asked if they felt good about their culture or ethnic background (see Table 43). Twelve students (92\%) responded that they strongly agreed that they felt good about their ethnic back ground and one student (8\%) responded that he disagreed that he felt good about his own ethnic group (see Table 43). 
The next three questions on the MEIM required students to identify their ethnicity (see Table 44), their father’s ethnicity (see Table 45), and their mother’s ethnicity (see Table 46). Nine students (62\%) at Poor Folks College reported their ethnicity was Hispanic (see Table 44). Five students (38\%) reported their ethnicity as mixed with their parents being from two different groups (see Table 44).

Table 44

Poor Folks Students’ Ethnicity

\begin{tabular}{lll}
\hline & $\begin{array}{l}\text { Hispanic of Hispanic, } \\
\text { including Mexican } \\
\text { American, Central } \\
\text { American, and others }\end{array}$ & $\begin{array}{l}\text { Mixed: Parents are from two } \\
\text { different groups }\end{array}$ \\
\hline $\begin{array}{l}\text { My ethnicity } \\
\text { is }\end{array}$ & 62 & 38 \\
& $(\mathrm{~N}=8)$ & $(\mathrm{N}=5)$ \\
\hline
\end{tabular}

With regard to their father's ethnicity, eight students (62\%) reported that their fathers were Hispanic (see Table 45). Five students (38\%) reported that their father's were mixed from two different groups (see Table 45).

Table 45

Poor Folks Father's Ethnicity

\begin{tabular}{lll}
\hline & $\begin{array}{l}\text { Hispanic of Hispanic, including } \\
\text { Mexican American, Central } \\
\text { American, and others }\end{array}$ & $\begin{array}{l}\text { Mixed: Parents are from } \\
\text { two different groups }\end{array}$ \\
\hline $\begin{array}{l}\text { My father's } \\
\text { ethnicity is }\end{array}$ & 62 & 38 \\
& $(\mathrm{~N}=8)$ & $(\mathrm{N}=5)$ \\
\hline
\end{tabular}


With regard to their mother's ethnicity, nine students (69\%) reported that their fathers were Hispanic (see Table 46). Four students (31\%) reported that their father's were mixed from two different groups (see Table 46).

Table 46

Poor Folks Mother's Ethnicity

\begin{tabular}{lll}
\hline & $\begin{array}{l}\text { Hispanic of Hispanic, } \\
\text { including Mexican } \\
\text { American, Central American, } \\
\text { and others }\end{array}$ & $\begin{array}{l}\text { Mixed: Parents are from } \\
\text { two different groups }\end{array}$ \\
\hline $\begin{array}{l}\text { My mother's } \\
\text { ethnicity is }\end{array}$ & 69 & 31 \\
& $(\mathrm{~N}=9)$ & $(\mathrm{N}=4)$ \\
\hline
\end{tabular}




\section{Chapter Six: Cross-Site Analysis of Two Maryland Community Colleges}

\section{Introduction}

The purpose of this study was to conduct qualitative research that would allow the researcher to interview Hispanic students who were enrolled in college and experiencing success as college students. The researcher wanted to gain insight about what enabled these students to experience success in college. Furthermore, the researcher wanted to learn how to assist students and families to become aware of programs and services that would help more students attend college in the future. In addition, the researcher's goal was to learn, through students, what resources are needed at the secondary level to assist with the transition from high school to college. By obtaining this information, hopefully school systems will begin to partner with each other and begin to see an increase in the enrollment of their Hispanic students. In this chapter, the researcher examined common themes which emerged at Knowledge College and Poor Folks College. The researcher interviewed a total of 26 students to discover emerging themes from their college experiences.

The Hispanic culture tends to rely heavily on the support system within the family unit (Castelllanos \& Jones, 2003). As pointed out by Arellano and Padill (1996) one of the major factors that contribute to the success of Hispanic students in higher education is the parental influence that exists within the family. Consequently, the expectations of the family members play a significant role in the outcome of student achievement.

\section{Comparison of Institutional Background}

The researcher visited Knowledge College first and was able to gather from interviewing students that many of these undergraduates had affluent parents who were able to help them with college preparation and choices. Some of these students had parents who had obtained degrees 
in other countries, made money to come the United States, (U.S.), and then pursued their college degrees once in the United States. One of the students interviewed had obtained a teaching degree in Columbia, but he was not able to use this degree in the United States, so he was currently working on a secondary teaching certificate in the U.S.

Knowledge College is located outside of a major city, so some of these students had parents who had professional careers and worked in the city. Therefore, many of these students had the advantage of living in the suburbs of a major city, but attended a small college.

Poor Folks College, on the other hand, presented a much poorer socio-economic class of students. Only one student reported that his mother had attended college, but he was not sure if she graduated. Consequently, this researcher perceived that 13 (100\%) of the students interviewed at Poor Folks College were first-generation college students.

\section{Study Participants}

When describing the environments where they were raised, this researcher concluded that the majority of the students were close with their parents and families. Twelve students (92\%) from Knowledge College reported that they were close to their parents, and seven students (54\%) from Poor Folks College reported that they were close with their parents and families (see Table 47). Six students (46\%) at Poor Folks College reported that they lived in a low socio-economic environment when they discussed their living environments; however, this researcher perceived that this number was much higher. For example, ten students (77\%) at Poor Folks College reported that their parents had not attended any type of schooling outside of high school, and all ten students received financial aid. Consequently, this researcher perceived that the socioeconomic status may be different than how some students responded. Three students (23\%) from Knowledge College reported that they lived in poor living conditions (see Table 47). 
Seven students (54\%) from Knowledge College reported that they lived in friendlier environments, and three students (23\%) from Knowledge College reported that they lived in a livelier environment (see Table 47).

Table 47

Environments Where Students Were Raised

\begin{tabular}{llllccc}
\hline $\begin{array}{l}\text { Interview response: } \\
\text { Describe your } \\
\text { childhood } \\
\text { environment }\end{array}$ & $\mathrm{N}$ & Knowledge & Poor Folks & $\begin{array}{c}\text { Number of } \\
\text { responses } \\
(\mathrm{N}=38)\end{array}$ & $\begin{array}{c}\text { \% based upon } \\
\text { the number of } \\
\text { respondents } \\
\text { (N=26) }\end{array}$ \\
\hline $\begin{array}{l}\text { Close connection } \\
\text { with their families }\end{array}$ & 12 & 92 & 7 & 54 & 19 & 73 \\
\hline $\begin{array}{l}\text { Poor living } \\
\text { conditions }\end{array}$ & 3 & 23 & 6 & 46 & 9 & 27 \\
\hline $\begin{array}{l}\text { Friendlier } \\
\text { living conditions }\end{array}$ & 7 & 54 & 0 & 0 & 7 & 12 \\
\hline $\begin{array}{l}\text { Lived in a livelier } \\
\text { environment }\end{array}$ & 3 & 23 & 0 & 0 & 3 & 34 \\
\hline
\end{tabular}

After questioning students about their childhood environments, the researcher asked students about their parents' educational backgrounds. Responses from students overwhelmingly showed that students who were from Poor Folks College were definitely at a disadvantage when compared to those of Knowledge College (see Table 48). Ten students (77\%) from Poor Folks reported that neither parent had attended college compared to three students (23\%) at Knowledge. Moreover, eight students (62\%) from Knowledge reported that both of their parents had graduated from college compared to none of the students (0\%) from Poor Folks College reporting that that both of their parents attended college (see Table 48). Three students (23\%) from Knowledge College reported that at least one of their parents had attended college, and only one student (8\%) student from Poor Folks College reported that his mother attended college. Two students (15\%) from Poor Folks College reported that their fathers attended a trade school, but they were not sure what they were called. 
Table 48

Parents’ Educational Backgrounds

\begin{tabular}{lllllcc}
\hline $\begin{array}{l}\text { Interview response: } \\
\begin{array}{l}\text { Educational } \\
\text { background of } \\
\text { parents }\end{array}\end{array}$ & $\mathrm{N}$ & $\%$ & $\mathrm{~N}$ & $\%$ & $\begin{array}{c}\text { Kumber of } \\
\text { responses } \\
(\mathrm{N}=27)\end{array}$ & $\begin{array}{c}\text { \% based upon } \\
\text { the number of } \\
\text { respondents } \\
\text { (N=26) }\end{array}$ \\
\hline $\begin{array}{l}\text { Neither parent } \\
\text { attended college }\end{array}$ & 3 & 23 & 10 & 77 & 13 & 50 \\
\hline $\begin{array}{l}\text { Both parents attended } \\
\text { college }\end{array}$ & 8 & 62 & 0 & 0 & 8 & 31 \\
\hline $\begin{array}{l}\text { One parent attended } \\
\text { college }\end{array}$ & 3 & 23 & 1 & 8 & 4 & 8 \\
\hline $\begin{array}{l}\text { One parent attended } \\
\text { trade school }\end{array}$ & 0 & 0 & 2 & 15 & 2 & \\
\hline
\end{tabular}

Although the socio-economic status was extremely different at the two schools, emerging themes with regard to the Hispanic population and the expectations of the culture were evident. Students discussed the value of family and the expectations that family members had for each other. Castellanos and Jones (2003) report that family is considered the most important institution within the Hispanic culture. Students from both schools discussed the importance they had with regard to their responsibilities to their families. Students interviewed were very clear that their family’s needs came before their educational desires.

The researcher asked students who was most influential in their decision to attend college (see Table 49). Twenty students (77\%) reported that it was their mothers who were most insistent that their children get an education. These students reported the hardships that their parents faced when trying to obtain jobs and pass tests. For example, forestry major, Steve Morgan reported,

My dad has always had jobs here and jobs there. He hasn’t really had a steady job. He works all the time, but there are several of my uncles and my dad who mainly work together. It is very hard because they are always looking for the next job. So, like my 
mom, she always tells me that I have to go to school. I have to an education. I have to have a job where I don’t wear my body out.

Two students (8\%) responded that their fathers were most influential in their decisions to attend college. Two students (8\%) responded that it was their spouses who helped them decide to go to college. One student (4\%) responded that he was the only person who influenced himself to attend college, and one student (4\%) responded that a counselor influenced her to attend college(see Table 49) .

Table 49

\section{Most Influential Person}

\begin{tabular}{|c|c|c|c|c|c|c|}
\hline \multirow{2}{*}{$\begin{array}{l}\text { Interview response: } \\
\text { Person who was } \\
\text { most influential in } \\
\text { persuading you to } \\
\text { attend college }\end{array}$} & \multicolumn{2}{|c|}{ Knowledge } & \multicolumn{2}{|c|}{ Poor Folks } & \multirow{2}{*}{$\begin{array}{l}\text { Number of } \\
\text { responses } \\
(\mathrm{N}=26)\end{array}$} & \multirow{2}{*}{$\begin{array}{l}\% \text { based upon } \\
\text { the number of } \\
\text { respondents } \\
(\mathrm{N}=26)\end{array}$} \\
\hline & $\mathrm{N}$ & $\%$ & $\mathrm{~N}$ & $\%$ & & \\
\hline Mother & 10 & 77 & 10 & 77 & 20 & 77 \\
\hline Father & 1 & 8 & 1 & 8 & 2 & 8 \\
\hline Spouse & 2 & 15 & 0 & 0 & 2 & 8 \\
\hline Self & 0 & 0 & 1 & 8 & 1 & 4 \\
\hline Counselor & 0 & 0 & 1 & 8 & 1 & 4 \\
\hline
\end{tabular}

Students at both institutions also reported that they chose to attend their respective colleges because of the proximity of their homes (see Table 50). Nine students (69\%) from Poor Folks College reported that they attended their respective college because it was close to their homes and families. Five students (38\%) from Knowledge College reported that they attended their respective college for the same reasons. 
Table 50

Decision to Attend a Certain College

\begin{tabular}{|c|c|c|c|c|c|c|}
\hline \multirow{2}{*}{$\begin{array}{l}\text { Interview response: } \\
\text { Why students chose } \\
\text { to attend these } \\
\text { colleges }\end{array}$} & \multicolumn{2}{|c|}{ Knowledge } & \multicolumn{2}{|c|}{ Poor Folks } & \multirow{2}{*}{$\begin{array}{c}\text { Number of } \\
\text { responses } \\
(\mathrm{N}=36)\end{array}$} & \multirow{2}{*}{$\begin{array}{l}\text { \% based upon the } \\
\text { number of } \\
\text { respondents } \\
(\mathrm{N}=26)\end{array}$} \\
\hline & $\mathrm{N}$ & $\%$ & $\mathrm{~N}$ & $\%$ & & \\
\hline Proximity & 5 & 38 & 9 & 69 & 14 & 54 \\
\hline $\begin{array}{l}\text { Affordable college } \\
\text { tuition }\end{array}$ & 6 & 46 & 8 & 62 & 14 & 54 \\
\hline $\begin{array}{l}\text { Programs for host } \\
\text { families }\end{array}$ & 3 & 23 & 0 & 0 & 3 & 12 \\
\hline $\begin{array}{l}\text { Programs for } \\
\text { specific degrees }\end{array}$ & 0 & 0 & 3 & 23 & 3 & 12 \\
\hline Sports scholarships & 2 & 15 & 0 & 0 & 2 & 8 \\
\hline
\end{tabular}

Tinto (1993) discusses that minority students who attend college may choose to attend colleges that are close to home because they may have family responsibilities that keep them closer to home. Three students (12\%) reported that they would not be able to attend any other college other than the community college in their neighborhoods because of their children. One nursing student reported,

I am a single mom. My mom helps me with my daughter when I am at school. There would be no way that I could attend a college anywhere else because I would have no one to watch my daughter. I also work. I am a waitress, so my mom watches my daughter while I am at work too. And now I am an intern, so I will have to kind of like two jobs. That is why I am at this college.

According to Tinto (1993) attending college may not be an equal opportunity for all students. Tinto (1993) reports that for married female students, family responsibilities may outweigh the possibility of a college degree. This is evident as this nursing student reported, 
Oh, I actually decided that I wanted to go back to school and that was a really big deal for me, but I knew that my kids would come first. My husband has a good job, so I know that my first job is my kids, and then it is my school. Plus, with my husband's job, I know that we might have to move, so I know that if that happens, I will quit. I should graduate in May though, so I don’t see anything like that happening.

A thirty-five-year-old business major commented,

There was no choice as the where I attended college. When I started college five years ago I only had a bike, so I could only go to this college because I could ride my bike from home, and it was still 20 miles.

Eight students (62\%) from Poor Folks College reported that the cheap cost of tuition was reason they attended their respective college. Six students (46\%) from Knowledge College reported that they attended Knowledge because of the cheap cost of tuition (see table 50). Three students (23\%) from Knowledge discussed that they came to Knowledge because of the program that allowed them to come to the U.S. Three students from Poor Folks (23\%) commented that they came to Poor Folks College because of the health programs that the college offers (see Table 50). Two students (15\%) from Knowledge attended school because of sports scholarships.

Students were asked what their families expected of them now that they were in college (see Table 51). Ten students (77\%) from Knowledge College reported that their families insisted that they were to transfer to a four-year college after they completed their two-year degrees compared to only two students (15\%) at Poor Folks College who reported that their parents expected them to complete a four-year degree after they graduated from Poor Folks College (see Table 51). Ten students (77\%) from Poor Folks College reporting that their parents expected them to graduate with a two-year degree. Three students (23\%) from Knowledge College 
reported that their parents expected them to complete their two-year degrees. Three students (23\%) from Knowledge reported that their parents expected them to learn English while they were attending college (see Table 51).

Table 51

Family Expectations

\begin{tabular}{|c|c|c|c|c|c|c|}
\hline \multirow{2}{*}{$\begin{array}{l}\text { Interview response: } \\
\text { Expectations of } \\
\text { family members }\end{array}$} & \multicolumn{2}{|c|}{ Knowledge } & \multicolumn{2}{|c|}{ Poor Folks } & \multirow{2}{*}{$\begin{array}{l}\text { Number of } \\
\text { responses } \\
(\mathrm{N}=36)\end{array}$} & \multirow{2}{*}{$\begin{array}{l}\text { \% based upon the } \\
\text { number of } \\
\text { respondents } \\
(\mathrm{N}=26)\end{array}$} \\
\hline & $\mathrm{N}$ & $\%$ & $\mathrm{~N}$ & $\%$ & & \\
\hline $\begin{array}{l}\text { Complete a two- } \\
\text { year degree }\end{array}$ & 3 & 23 & 10 & 77 & 13 & 50 \\
\hline $\begin{array}{l}\text { Complete a four- } \\
\text { year degree }\end{array}$ & 10 & 77 & 2 & 15 & 12 & 46 \\
\hline $\begin{array}{l}\text { Become fluent in } \\
\text { English }\end{array}$ & 3 & 23 & 0 & 0 & 3 & 12 \\
\hline
\end{tabular}

Students were asked what types of challenges they faced when deciding to attend college (see Table 52). Although a total of 24 students (92\%) reported that they worked and had to in order to support either themselves or their families or both, only four students (15\%) said that their work schedules, at times, made it impossible for them to attend classes.

A total of thirteen students (50\%) reported that they had financial challenges when deciding to go to college. Seven (54\%) of these students were from Poor Folks, and six (46\%) of these students were from Knowledge College. Seven students (27\%) from both schools reported that they had difficulties in their classes because of a language barrier with reading, speaking, and comprehending English. Hernandez (2002) reported that Hispanic students who were involved in a qualitative study reported that they had difficulty adjusting to college due to a lack of preparedness from high school. He further stated that these findings were similar to that of a study conducted by Richardson and Skinner (1992) where these researchers also cited the reason for underachievement with regard to minority students was due to lack of preparation. In their 
research, students reported that they often wondered if they had what it took to make it in college and questioned their academic preparation (Richardson \& Skinner).

Six students (23\%) all of whom were from Poor Folks College were not able to pass the standard placement tests that admitted them to their English and math classes, so they had to take remedial courses (see Table 52).

Table 52

\section{Challenges Students Encountered}

\begin{tabular}{lllllcc}
\hline $\begin{array}{l}\text { Interview response: } \\
\begin{array}{l}\text { Challenges students } \\
\text { encountered }\end{array}\end{array}$ & Knowledge & Poor Folks & $\begin{array}{c}\text { Number of } \\
\text { responses } \\
(\mathrm{N}=48)\end{array}$ & $\begin{array}{c}\text { \% based upon the } \\
\text { number of } \\
\text { respondents } \\
\text { (N=26) }\end{array}$ \\
\hline Work & 3 & 23 & 1 & 8 & 4 & 15 \\
\hline Financial struggles & 6 & 46 & 7 & 54 & 13 & 50 \\
\hline $\begin{array}{l}\text { Difficulty } \\
\text { understanding }\end{array}$ & 3 & 23 & 4 & 31 & 7 & 27 \\
$\begin{array}{l}\text { English } \\
\text { Passing } \\
\text { standardized tests }\end{array}$ & 0 & 0 & 6 & 46 & 6 & 23 \\
\hline
\end{tabular}

With regard to barriers due to work schedules, when this researcher went to Poor Folks College to interview one of the students, she discovered that the class was being recorded. The researcher had already talked with this student's professor and was given permission to interview him during the class. However, once the researcher went to the class, she was informed that the student would not be there because of his work schedule. Ironically, after this researcher was able to interview the student, she was surprised to learn that the professor was taping the class for this student. Apparently, this student had worked extremely hard to graduate, and his work schedule was changed. Consequently, he could not attend the Calculus class that he needed in 
order to graduate. This professor was willing to tape the classes for him, so the student could watch them at home and still participate in the class. This business major commented, I couldn’t believe it when they changed my work schedule. They would not be lenient and give me another shift. I thought about quitting and getting another job, but I had been at this one for so long that I was making really good money. I went to my professor and explained the situation. I thought for sure that he would tell me to drop his class, but he said that he was going to try to help me because he knew how hard I had worked for this degree. I couldn't believe that he was going to do this for me. I just was like, "No way.” I tried to come to as many classes as I could, but it was only like two that I was able to attend, so I always watch the classes on tape, which actually has been really good for me because I can rewind what my professor is saying so I kind of have an advantage in that way.

Students were asked how their high schools supported their transition from high school to college (see Table 53). Twelve students (46\%) responded that they had assistance from their school guidance counselors. Seven of these students (54\%) were from Poor Folks College, and five (38\%) of these students were from Knowledge. Eleven students (42\%) said that they had no help transitioning from high school to college. Six of these students (46\%) of these students were from Poor Folks and five students (38\%) were from Knowledge. Four students (15\%) reported that they had assistance through programs that existed in their high schools, and two students (8\%) reported their assistance was through coaches at their secondary and postsecondary schools. 
Table 53

Help Students Had Transferring from High School to College

\begin{tabular}{|c|c|c|c|c|c|c|}
\hline \multirow{2}{*}{$\begin{array}{l}\text { Interview response: } \\
\text { Why students chose } \\
\text { to attend these } \\
\text { colleges }\end{array}$} & \multicolumn{2}{|c|}{ Knowledge } & \multicolumn{2}{|c|}{ Poor Folks } & \multirow{2}{*}{$\begin{array}{l}\text { Number of } \\
\text { responses } \\
(\mathrm{N}=26)\end{array}$} & \multirow{2}{*}{$\begin{array}{l}\text { \% based upon the } \\
\text { number of } \\
\text { respondents } \\
(\mathrm{N}=26)\end{array}$} \\
\hline & $\mathrm{N}$ & $\%$ & $\mathrm{~N}$ & $\%$ & & \\
\hline $\begin{array}{l}\text { Help from guidance } \\
\text { counselor }\end{array}$ & 5 & 38 & 7 & 54 & 12 & 46 \\
\hline $\begin{array}{l}\text { Did not receive help } \\
\text { in high school }\end{array}$ & 5 & 38 & 6 & 46 & 11 & 42 \\
\hline $\begin{array}{l}\text { Programs in their } \\
\text { high schools }\end{array}$ & 3 & 23 & 1 & 8 & 4 & 15 \\
\hline Sports scholarships & 2 & 15 & 0 & 0 & 2 & 7 \\
\hline
\end{tabular}

Students were asked about how they found out about financial aid and whether or not they were currently receiving financial aid (see Table 54). Students from both schools reported that they were currently receiving financial aid; however, 12 students (92\%) from Poor Folks reported that they were receiving financial aid compared to 5 students (38\%) who were receiving financial aid at Knowledge College. Overall, 17 students (65\%) of the students interviewed were receiving financial aid (see Table 54). Nine students (75\%) from Poor Folks College reported that they were receiving Pell grants, although, one student was not sure if that was, was it was called. Three students (23\%) from Knowledge College reported that they were receiving Pell Grants. Two students (15\%) from Knowledge College were receiving monies though athletic scholarships, and one student (8.0\%) from Knowledge was receiving assistance though the army (see Table 54). 
Table 54

Financial Aid

\begin{tabular}{|c|c|c|c|c|c|c|}
\hline \multirow{2}{*}{$\begin{array}{l}\text { Interview response: } \\
\text { Students receiving } \\
\text { help with paying for } \\
\text { college }\end{array}$} & \multicolumn{2}{|c|}{ Knowledge } & \multicolumn{2}{|c|}{ Poor Folks } & \multirow{2}{*}{$\begin{array}{c}\text { Number of } \\
\text { responses } \\
(\mathrm{N}=32)\end{array}$} & \multirow{2}{*}{$\begin{array}{l}\text { \% based upon the } \\
\text { number of } \\
\text { respondents } \\
(\mathrm{N}=26)\end{array}$} \\
\hline & $\mathrm{N}$ & $\%$ & $\mathrm{~N}$ & $\%$ & & \\
\hline $\begin{array}{l}\text { Students receiving } \\
\text { financial aid }\end{array}$ & 5 & 38 & 12 & 92 & 17 & 65 \\
\hline $\begin{array}{l}\text { Students receiving } \\
\text { Pell grants }\end{array}$ & 3 & 23 & 9 & 75 & 12 & 46 \\
\hline $\begin{array}{l}\text { Athletic } \\
\text { scholarships }\end{array}$ & 2 & 15 & 0 & 0.0 & 2 & 8 \\
\hline $\begin{array}{l}\text { Free tuition through } \\
\text { the army }\end{array}$ & 1 & 8 & 0 & 0.0 & 1 & 4 \\
\hline
\end{tabular}

Students were asked what resources they used at the colleges they were attending (see Table 55). Eighteen students (69\%) reported that they used the library because they could use the computers and get assistance through school personnel at the library. Six students (23\%) reported that they used the tutoring services provided by the school (see Table 55). Five students from Poor Folks College (38\%) reported that they used the writing labs to get help with writing assignments, and two students (15\%) from Knowledge College reported e-mailing professors as a resource they used (see Table 55). 
Table 55

Resources Students Used at College

\begin{tabular}{|c|c|c|c|c|c|c|}
\hline \multirow{2}{*}{$\begin{array}{l}\text { Interview response: } \\
\text { What resources } \\
\text { students use at their } \\
\text { colleges }\end{array}$} & \multicolumn{2}{|c|}{ Knowledge } & \multicolumn{2}{|c|}{ Poor Folks } & \multirow{2}{*}{$\begin{array}{l}\text { Number of } \\
\text { responses } \\
(\mathrm{N}=31)\end{array}$} & \multirow{2}{*}{$\begin{array}{l}\text { \% based upon the } \\
\text { number of } \\
\text { respondents } \\
(\mathrm{N}=26)\end{array}$} \\
\hline & $\mathrm{N}$ & $\%$ & $\mathrm{~N}$ & $\%$ & & \\
\hline Library & 11 & 85 & 7 & 54 & 18 & 69 \\
\hline Tutoring & 2 & 15 & 4 & 31 & 6 & 23 \\
\hline Writing lab & 0 & 0 & 5 & 38 & 5 & 19 \\
\hline $\begin{array}{l}\text { Interaction with } \\
\text { faculty }\end{array}$ & 2 & 15 & 0 & 0 & 2 & 8 \\
\hline
\end{tabular}

Students were questioned about how socially connected they felt with the college (see Table 56). Tinto (1993) discusses that departure from college is most likely caused by the lack of social and intellectual integration into a membership or community on campus. Tinto (1993) is emphatic that student success relies heavily on the interaction among students and the peers and faculty. Furthermore, in order for colleges to retain their students, Tinto (1993) suggests that students’ needs social and academic needs must be addressed. Lanaan (2000) reports that attending a community college after high school graduation is a more popular route for minority students, so this researcher questioned students about how integrated they felt in their respective colleges.

Twenty-five students (96\%) reported that they felt socially connected to faculty at their colleges. Furthermore, students from both colleges reported that they felt a connection with faculty members, and that most of the faculty members truly cared about their success and persistence in college. 
Twelve students (46\%) reported that they felt socially connected with students on their respective campuses Seven of these students (54\%) were from Knowledge College, and five (38\%) of these students were from Poor Folks College (see Table 56). It is important to note that although students reported that they felt socially connected, students from both colleges reported that they were not aware of many other Hispanic students who attended the college, and they would be extremely interested in meeting other Hispanic students who attended their colleges. Four students (31\%) from Knowledge College reported that they did not feel socially connected to students on their campus, and eight students (62\%) from Poor Folks College reported that they did not feel socially connected to students on their campus. Furthermore, four students (31\%) from Knowledge College and 11 students (85\%) from Poor Folks College reported that they did not feel socially connected to the Hispanic population on campus (see Table 56).

Table 56

Social Connection to College

\begin{tabular}{|c|c|c|c|c|c|c|}
\hline \multirow{2}{*}{$\begin{array}{l}\text { Interview response: } \\
\text { Are students socially } \\
\text { connected to their } \\
\text { colleges? }\end{array}$} & \multicolumn{2}{|c|}{ Knowledge } & \multicolumn{2}{|c|}{ Poor Folks } & \multirow{2}{*}{$\begin{array}{c}\text { Number of } \\
\text { responses } \\
(\mathrm{N}=64)\end{array}$} & \multirow{2}{*}{$\begin{array}{l}\text { \% based upon the } \\
\text { number of } \\
\text { respondents } \\
(\mathrm{N}=26)\end{array}$} \\
\hline & $\mathrm{N}$ & $\%$ & $\mathrm{~N}$ & $\%$ & & \\
\hline $\begin{array}{l}\text { Feel socially } \\
\text { connected to the } \\
\text { faculty }\end{array}$ & 13 & 100 & 12 & 92 & 25 & 96 \\
\hline $\begin{array}{l}\text { Feel socially } \\
\text { connected to } \\
\text { students on their } \\
\text { campuses }\end{array}$ & 7 & 54 & 5 & 38 & 12 & 46 \\
\hline $\begin{array}{l}\text { Do not feel socially } \\
\text { connected to } \\
\text { students on their } \\
\text { campuses }\end{array}$ & 4 & 31 & 8 & 62 & 12 & 46 \\
\hline $\begin{array}{l}\text { Do not feel socially } \\
\text { connected to } \\
\text { Hispanic students on } \\
\text { their campuses }\end{array}$ & 4 & 31 & 11 & 84 & 15 & 58 \\
\hline
\end{tabular}


Students were questioned about whether or not they participated in any type of club or organization that involved minority students or some type of ethnicity awareness of Hispanic students (see Table 57). Braxton, Hirschy, and McClendon (2004) reported that if students are in an environment where their culture is not the dominant culture, then there must be some kind or organization that exists that shares the same values, beliefs, and customs of these students if students are expected to remain in college. Tinto (1997) discusses that institutions that promote improving the social climate and making in more in tune with the lives of the students on the campus, then those students will have a much more positive college experience and will be must more likely to stay and earn their degrees. Students must have a sense of belonging. They must have programs, services, centers, mentors, and tutoring in order to experience a successful transition in higher education (Tinto, 1997).

When questioned about how many on-campus clubs interviewees participated in, 11 students (42\%) reported that they were not aware of any clubs that existed on campus (see Table 57). Eight of these students (62\%) were from Knowledge College, and three of these students (23\%) were from Poor Folks College (see Table 57). Seven students (54\%) from Poor Folks College reported that they were aware of clubs that existed on campus, but that they did not participate. Two students (15\%) from Knowledge reported that they were aware of clubs, but that they did not participate (see Table 57). Three students (23\%) from Poor Folks College reported that they did participate in clubs that pertained to their degrees, however, only one student (4\%) from both schools reported that she was involved in a club that was designed to meet the needs of minority students. However, this club was an organization that was opened to community members. It was not affiliated with the college. Two students (15\%) from 
Knowledge reported that they participated in sports, so they felt that it was similar to

participation in a club.

Table 57

Student Participation in Organizations

\begin{tabular}{lcccccc}
\hline $\begin{array}{l}\text { Interview response: } \\
\begin{array}{l}\text { Do students participate } \\
\text { in colleges clubs and } \\
\text { organizations? }\end{array}\end{array}$ & $\begin{array}{c}\text { Knowledge } \\
\text { College }\end{array}$ & $\begin{array}{c}\text { Poor Folks } \\
\text { College }\end{array}$ & $\begin{array}{c}\text { Number of } \\
\text { responses } \\
(\mathrm{N}=25)\end{array}$ & $\begin{array}{c}\text { \% based upon the } \\
\text { number of } \\
\text { respondents } \\
(\mathrm{N}=26)\end{array}$ \\
\hline $\begin{array}{l}\text { Are not aware of clubs } \\
\text { or organizations on } \\
\text { campus }\end{array}$ & 8 & 62 & 3 & 23 & 11 & 42 \\
\hline $\begin{array}{l}\text { Aware of clubs but do } \\
\text { not participate }\end{array}$ & 2 & 15 & 7 & 54 & 9 & 35 \\
\hline $\begin{array}{l}\text { Participate in clubs that } \\
\text { pertain to their degrees }\end{array}$ & 0 & 0 & 3 & 23 & 3 & 8 \\
\hline Participation in sports & 2 & 15 & 0 & 0 & 2 & \\
\hline
\end{tabular}

Students were asked how they felt about their classes at their respective colleges, and if they felt that their instructors cared about their progress (see Table 58). Twelve students (92\%) at Poor Folks College reported that they enjoyed their classes compared to five students (38\%) at Knowledge College who reported that they enjoyed their classes. Furthermore, nine (69\%) students are Poor Folks College reported that they felt that their professors cared about their progress compared to five students (38\%) at Knowledge who reported that they felt that their professors cared about their progress. Four students (31\%) at Knowledge College reported that they loved their classes (see Table 58). 
Table 58

Feelings about Classes

\begin{tabular}{lcccccc}
\hline $\begin{array}{l}\text { Interview response: } \\
\begin{array}{l}\text { How do students feel } \\
\text { about their classes }\end{array}\end{array}$ & $\begin{array}{c}\text { Knowledge } \\
\text { College }\end{array}$ & $\begin{array}{c}\text { Poor Folks } \\
\text { College }\end{array}$ & $\begin{array}{c}\text { Number of } \\
\text { responses } \\
(\mathrm{N}=35)\end{array}$ & $\begin{array}{c}\text { \% based upon the } \\
\text { number of } \\
\text { respondents } \\
\text { (N=26) }\end{array}$ \\
\hline Enjoy classes & 5 & 38 & 12 & 92 & 17 & 65 \\
\hline $\begin{array}{l}\text { Feel that professors } \\
\text { care about their progress }\end{array}$ & 5 & 38 & 9 & 69 & 14 & 15 \\
\hline Love their classes & 4 & 0 & 0 & 0 & 4 & \\
\hline
\end{tabular}

Students were asked if they encountered any obstacles while they were in college (see Table 59). A total of 13 students (50\%) interviewed reported that finances were a constant obstacle they had while attending college. As previously stated, 24 students (92\%) reported that they had to work in order to make money for either themselves or their families while attending college. Four students (31\%) from Knowledge College reported that time management was an obstacle, and four students (31\%) from Poor Folks College reported that working while attending college was an obstacle (see Table 59).

Table 59

Obstacles Students Encountered

\begin{tabular}{|c|c|c|c|c|c|c|}
\hline \multirow{2}{*}{$\begin{array}{l}\text { Interview response: } \\
\text { Did students } \\
\text { encounter obstacles } \\
\text { while attending } \\
\text { college? }\end{array}$} & \multicolumn{2}{|c|}{ Knowledge } & \multicolumn{2}{|c|}{ Poor Folks } & \multirow{2}{*}{$\begin{array}{c}\text { Number of } \\
\text { responses } \\
(\mathrm{N}=21)\end{array}$} & \multirow{2}{*}{$\begin{array}{l}\text { \% based upon the } \\
\text { number of } \\
\text { respondents } \\
(\mathrm{N}=26)\end{array}$} \\
\hline & $\mathrm{N}$ & $\%$ & $\mathrm{~N}$ & $\%$ & & \\
\hline Finances & 6 & 46 & 7 & 54 & 13 & 50 \\
\hline $\begin{array}{l}\text { Time } \\
\text { Management }\end{array}$ & 4 & 31 & 0 & 0 & 4 & 15 \\
\hline Work Schedules & 0 & 0 & 4 & 31 & 4 & 15 \\
\hline
\end{tabular}


Students were asked if they could teach others about their culture, what they would teach them (see Table 60). Twelve students (46\%) from both colleges responded that they would like to teach others about their foods (see Table 60). Six students (23\%) from both colleges responded that they would teach others about stereotypes and more about their ways of life so that others would feel more comfortable around Hispanic people. Three students (23\%) from Knowledge College reported that they would like to teach others about how much fun they have in their culture. Three students (23\%) from Poor Folks College commented that they would like to learn more about their own culture, and two students (15\%) from Knowledge College reported that they would like to teach others why they want to come to the U.S.

Table 60

Education of Culture

\begin{tabular}{|c|c|c|c|c|c|c|}
\hline Interview & \multicolumn{2}{|c|}{ Knowledge } & \multicolumn{2}{|c|}{ Poor Folks } & \multirow{2}{*}{$\begin{array}{l}\text { Number of } \\
\text { responses } \\
(\mathrm{N}=26)\end{array}$} & \multirow{2}{*}{$\begin{array}{l}\text { \% based upon the } \\
\text { number of } \\
\text { respondents } \\
(\mathrm{N}=26)\end{array}$} \\
\hline $\begin{array}{l}\text { others about their } \\
\text { culture }\end{array}$ & $\mathrm{N}$ & $\%$ & $\mathrm{~N}$ & $\%$ & & \\
\hline Food & 3 & 23 & 9 & 69 & 12 & 46 \\
\hline $\begin{array}{l}\text { Awareness of } \\
\text { stereotypes }\end{array}$ & 2 & 15 & 4 & 31 & 6 & 23 \\
\hline $\begin{array}{l}\text { Want to learn } \\
\text { more about } \\
\text { their culture } \\
\end{array}$ & 0 & 0 & 3 & 23 & 3 & 12 \\
\hline $\begin{array}{l}\text { Friendlier } \\
\text { atmosphere }\end{array}$ & 3 & 23 & 0 & 0 & 3 & 12 \\
\hline $\begin{array}{l}\text { Why we want } \\
\text { to come to } \\
\text { the U.S. }\end{array}$ & 2 & 15 & 0 & 0 & 2 & 8 \\
\hline
\end{tabular}

Students were asked if they had any experiences that made them more aware of their ethnicity (see Table 61). 
Table 61

Ethnicity Experiences

\begin{tabular}{|c|c|c|c|c|c|c|}
\hline $\begin{array}{l}\text { Interview } \\
\text { response: } \\
\text { Experiences that } \\
\text { made students } \\
\text { more aware of } \\
\text { their ethnicity }\end{array}$ & $\mathrm{Kr}$ & ledge & $\mathrm{N}$ & olks & $\begin{array}{c}\text { Number of } \\
\text { responses } \\
(\mathrm{N}=29)\end{array}$ & $\begin{array}{l}\text { \% based upon the } \\
\text { number of } \\
\text { respondents } \\
(\mathrm{N}=26)\end{array}$ \\
\hline $\begin{array}{l}\text { Treated } \\
\text { differently } \\
\text { because of } \\
\text { ethnicity }\end{array}$ & 7 & 54 & 8 & 62 & 15 & 58 \\
\hline $\begin{array}{l}\text { Have not noticed } \\
\text { any kind of } \\
\text { awareness }\end{array}$ & 6 & 46 & 5 & 38 & 11 & 42 \\
\hline $\begin{array}{l}\text { Encountered } \\
\text { positive } \\
\text { experiences } \\
\end{array}$ & 0 & 0 & 2 & 15 & 2 & 8 \\
\hline Racial profiling & 2 & 15 & 0 & 0 & 2 & 8 \\
\hline
\end{tabular}

Fifteen students (58\%) from both schools responded that they had encountered experiences which made them more aware of their ethnicity. However, students from Knowledge College tended to discuss that most of the differences came from times where they had to speak in public or discuss reports within the classroom. Students from Knowledge tended to answer the question regarding experiences they had encountered in the school setting.

Students from Poor Folks College on the other hand tended to answer the question not within the college setting but within the setting of the town where they resided. A human services major explained this by commenting,

I always know that when I am talking to my friends in Spanish that other people are making faces, you know gestures, like why can’t they use English. I am so tired of hearing people say, they are in our country, they should use our language. The funny thing is, this is my country too. I was born here. I am not a citizen of any other country- 
only America. So, like in that sense it is kind of funny but aggravating at the same time. You know, I just want to say. I was born in the states just like you. Maybe you need to go back and learn some history as to why so many people in our country speak Spanish. But, then I just don't worry about it because I know the mentality. But it happens all the time-especially in this area. This area is a difficult area to be um well, not White. You know and sometimes, I just want to say look at the numbers. We are increasing. Maybe sometimes that is what the fear is about. We are taking over or something. I don't know but it is all so silly to me [pause] but extremely frustrating as well.

Several students discussed that they believe that Hispanics are perceived lazy individuals, and one student even discussed that she does not know why Hispanic people have been thought of as dirty. These students discussed the negative stereotypes that people think about Hispanic people and that typically the people who make comments have never been around the Hispanic culture and have no reason to make these comments. A thirty-five-year-old business major commented,

Oh, I guess the ways that people stereotype Mexicans is somewhat annoying, but I just think that those people are so stupid that it doesn't bother me. I don't have any kids yet, but some of my friends do, and sometimes their kids get upset because of things that are said to them. I guess if I had kids and someone said something to them, it would make me angry, but I am not concerned with those people now.

Eleven students (42\%) from both colleges reported that they had not encountered any experiences because of their ethnicity (see Table 61). Two students (15\%) from Knowledge College reported that they had encountered experiences based on their ethnicity by racial 
profiling; however, it is important to note that these incidences did not occur on their college campus.

Students were asked if they thought they were affected in anyway, right now, because of their ethnicity (see Table 62). An overwhelming 18 students (69\%) reported that they did not feel that they were affected by their ethnicity. Five students (19\%) from both colleges reported that they did currently feel affected by their ethnicity (see Table 62).

Table 62

Ethnicity Awareness

\begin{tabular}{|c|c|c|c|c|c|c|}
\hline \multirow{2}{*}{$\begin{array}{l}\text { Interview response: } \\
\text { Have students been } \\
\text { affected because of } \\
\text { their ethnicity? }\end{array}$} & \multicolumn{2}{|c|}{ Knowledge } & \multicolumn{2}{|c|}{$\begin{array}{l}\text { Poor } \\
\text { Folks }\end{array}$} & \multirow{2}{*}{$\begin{array}{l}\text { Number of } \\
\text { responses } \\
(\mathrm{N}=25)\end{array}$} & \multirow{2}{*}{$\begin{array}{l}\text { \% based upon the } \\
\text { number of } \\
\text { respondents } \\
(\mathrm{N}=26)\end{array}$} \\
\hline & $\mathrm{N}$ & $\%$ & $\mathrm{~N}$ & $\%$ & & \\
\hline $\begin{array}{l}\text { Not aware of any } \\
\text { differences }\end{array}$ & 8 & 62 & 10 & 77 & 18 & 69 \\
\hline $\begin{array}{l}\text { Aware of } \\
\text { differences }\end{array}$ & 3 & 23 & 2 & 38 & 5 & 19 \\
\hline
\end{tabular}

\section{Cross-Site Analysis of MEIM}

In order to discover how students felt socially connected with their ethnicity and their confidence with their ethnicity identity awareness, students from both colleges completed the Multigroup Ethnicity Measure (MEIM).

When comparing the two schools, the researcher learned that when students were asked to respond if they had spent time trying to find out more about their ethnic groups such as its history, traditions, and customs, eight students (62\%) from Poor Folks College strongly agreed that they had and four students (31\%) from Poor Folks College responded that they had spent time (see Table 63). 
Students from Knowledge College, however, reported that four students (31\%) strongly agreed and 6 students (46\%) agreed that they had spent time trying to find out about their ethnic group (see Table 63). 


\section{Multigroup Ethnic Identity Measure Results}

Table 63

Cross-Site Analysis

\begin{tabular}{|c|c|c|c|c|c|c|c|c|}
\hline Item & $\begin{array}{l}4 \\
\text { SA } \\
\% \text { based on } \\
\text { the number } \\
\text { of responses } \\
(\mathrm{N}=13) \\
\text { Knowledge }\end{array}$ & $\begin{array}{l}4 \\
\text { SA } \\
\% \text { based on } \\
\text { the number } \\
\text { of responses } \\
(\mathrm{N}=13) \\
\text { Poor Folks }\end{array}$ & $\begin{array}{l}3 \\
A \\
\% \text { based on } \\
\text { the number } \\
\text { of responses } \\
(\mathrm{N}=13) \\
\text { Knowledge }\end{array}$ & $\begin{array}{l}3 \\
A \\
\% \text { based on } \\
\text { the number } \\
\text { of responses } \\
(\mathrm{N}=13) \\
\text { Poor Folks }\end{array}$ & $\begin{array}{l}2 \\
D \\
\% \text { based on } \\
\text { the number } \\
\text { of responses } \\
(\mathrm{N}=13) \\
\text { Knowledge }\end{array}$ & $\begin{array}{l}2 \\
D \\
\% \text { based on } \\
\text { the number } \\
\text { of responses } \\
(\mathrm{N}=13 \text { ) } \\
\text { Poor Folks }\end{array}$ & $\begin{array}{l}1 \\
\text { SD } \\
\% \text { based on } \\
\text { the number } \\
\text { of responses } \\
(\mathrm{N}=13) \\
\text { Knowledge }\end{array}$ & $\begin{array}{l}1 \\
\text { SD } \\
\% \text { based } \\
\text { on the } \\
\text { number of } \\
\text { responses } \\
(\mathrm{N}=13) \\
\text { Poor Folks }\end{array}$ \\
\hline $\begin{array}{l}\text { I have spent } \\
\text { time trying to } \\
\text { find out more } \\
\text { about my } \\
\text { ethnic groups } \\
\text { such as its } \\
\text { history, } \\
\text { traditions, and } \\
\text { custom. }\end{array}$ & $\begin{array}{l}31 \\
(N=4)\end{array}$ & $\begin{array}{l}62 \\
(\mathrm{~N}=8)\end{array}$ & $\begin{array}{l}46 \\
(N=6)\end{array}$ & $\begin{array}{l}31 \\
(N=4)\end{array}$ & $\begin{array}{l}23 \\
(N=3)\end{array}$ & $\begin{array}{l}8 \\
(N=1)\end{array}$ & $\begin{array}{l}0 \\
(\mathrm{~N}=0)\end{array}$ & $\begin{array}{l}0 \\
(\mathrm{~N}=0)\end{array}$ \\
\hline $\begin{array}{l}\text { I am active in } \\
\text { organizations } \\
\text { or social groups } \\
\text { that include } \\
\text { mostly } \\
\text { members of my } \\
\text { own ethnic } \\
\text { groups. }\end{array}$ & $\begin{array}{l}46 \\
(\mathrm{~N}=6)\end{array}$ & $\begin{array}{l}62 \\
(\mathrm{~N}=8)\end{array}$ & $\begin{array}{l}31 \\
(\mathrm{~N}=4)\end{array}$ & $\begin{array}{l}31 \\
(\mathrm{~N}=4)\end{array}$ & $\begin{array}{l}23 \\
(N=3)\end{array}$ & $\begin{array}{l}8 \\
(\mathrm{~N}=1)\end{array}$ & $\begin{array}{l}0 \\
(\mathrm{~N}=0)\end{array}$ & $\begin{array}{l}0 \\
(\mathrm{~N}=0)\end{array}$ \\
\hline $\begin{array}{l}\text { I have a clear } \\
\text { sense of my } \\
\text { ethnic } \\
\text { background } \\
\text { and what it } \\
\text { means for me. }\end{array}$ & $\begin{array}{l}77 \\
(\mathrm{~N}=10)\end{array}$ & $\begin{array}{l}69 \\
(N=9)\end{array}$ & $\begin{array}{l}23 \\
(N=3)\end{array}$ & $\begin{array}{l}31 \\
(N=4)\end{array}$ & $\begin{array}{l}0 \\
(\mathrm{~N}=0)\end{array}$ & $\begin{array}{l}0 \\
(\mathrm{~N}=0)\end{array}$ & $\begin{array}{l}0 \\
(\mathrm{~N}=0)\end{array}$ & $\begin{array}{l}0 \\
(\mathrm{~N}=0)\end{array}$ \\
\hline $\begin{array}{l}\text { I think a lot } \\
\text { about how my } \\
\text { life will be } \\
\text { affected by my } \\
\text { ethnic group } \\
\text { membership. }\end{array}$ & $\begin{array}{l}15 \\
(\mathrm{~N}=2)\end{array}$ & $\begin{array}{l}15 \\
(\mathrm{~N}=2)\end{array}$ & $\begin{array}{l}46 \\
(N=6)\end{array}$ & $\begin{array}{l}77 \\
(\mathrm{~N}=10)\end{array}$ & $\begin{array}{l}31 \\
(N=4)\end{array}$ & $\begin{array}{l}8 \\
(N=1)\end{array}$ & $\begin{array}{l}0 \\
(N=1)\end{array}$ & $\begin{array}{l}0 \\
(\mathrm{~N}=0)\end{array}$ \\
\hline $\begin{array}{l}\text { I am happy that } \\
\text { I am a member } \\
\text { of the group I } \\
\text { belong to. }\end{array}$ & $\begin{array}{l}92 \\
(\mathrm{~N}=12)\end{array}$ & $\begin{array}{l}85 \\
(\mathrm{~N}=11)\end{array}$ & $\begin{array}{l}8 \\
(\mathrm{~N}=1)\end{array}$ & $\begin{array}{l}15 \\
(N=2)\end{array}$ & $\begin{array}{l}0 \\
(\mathrm{~N}=0)\end{array}$ & $\begin{array}{l}0 \\
(\mathrm{~N}=0)\end{array}$ & $\begin{array}{l}0 \\
(\mathrm{~N}=0)\end{array}$ & $\begin{array}{l}0 \\
(\mathrm{~N}=0)\end{array}$ \\
\hline $\begin{array}{l}\text { I have a strong } \\
\text { sense of } \\
\text { belonging to } \\
\text { my own ethnic } \\
\text { group. }\end{array}$ & $\begin{array}{l}69 \\
(N=9)\end{array}$ & $\begin{array}{l}77 \\
(N=10)\end{array}$ & $\begin{array}{l}31 \\
(N=4)\end{array}$ & $\begin{array}{l}15 \\
(N=2)\end{array}$ & $\begin{array}{l}0 \\
(\mathrm{~N}=0)\end{array}$ & $\begin{array}{l}8 \\
(N=1)\end{array}$ & $\begin{array}{l}0 \\
(\mathrm{~N}=0)\end{array}$ & $\begin{array}{l}0 \\
(\mathrm{~N}=0)\end{array}$ \\
\hline
\end{tabular}


Table 63 (continued)

Cross-Site Analysis

\begin{tabular}{|c|c|c|c|c|c|c|c|c|}
\hline $\begin{array}{l}\text { I understand } \\
\text { pretty well } \\
\text { what my ethnic } \\
\text { group } \\
\text { membership } \\
\text { means to me. }\end{array}$ & $\begin{array}{l}69 \\
(N=9)\end{array}$ & $\begin{array}{l}62 \\
(N=8)\end{array}$ & $\begin{array}{l}31 \\
(\mathrm{~N}=4)\end{array}$ & $\begin{array}{l}38 \\
(\mathrm{~N}=5)\end{array}$ & $\begin{array}{l}0 \\
(\mathrm{~N}=0)\end{array}$ & $\begin{array}{l}0 \\
(\mathrm{~N}=0)\end{array}$ & $\begin{array}{l}0 \\
(\mathrm{~N}=0)\end{array}$ & $\begin{array}{l}0 \\
(\mathrm{~N}=0)\end{array}$ \\
\hline $\begin{array}{l}\text { In order to } \\
\text { learn more } \\
\text { about my } \\
\text { ethnic } \\
\text { background, I } \\
\text { have often } \\
\text { talked to other } \\
\text { people about } \\
\text { my ethnic } \\
\text { group. }\end{array}$ & $\begin{array}{l}46 \\
(\mathrm{~N}=6)\end{array}$ & $\begin{array}{l}54 \\
(\mathrm{~N}=7)\end{array}$ & $\begin{array}{l}38 \\
(N=5)\end{array}$ & $\begin{array}{l}38 \\
(\mathrm{~N}=5)\end{array}$ & $\begin{array}{l}15 \\
(\mathrm{~N}=2)\end{array}$ & $\begin{array}{l}8 \\
(\mathrm{~N}=1)\end{array}$ & $\begin{array}{l}0 \\
(\mathrm{~N}=0)\end{array}$ & $\begin{array}{l}0 \\
(\mathrm{~N}=0)\end{array}$ \\
\hline $\begin{array}{l}\text { I have a lot of } \\
\text { pride in my } \\
\text { ethnic group. }\end{array}$ & $\begin{array}{l}85 \\
(\mathrm{~N}=11)\end{array}$ & $\begin{array}{l}92 \\
(\mathrm{~N}=12)\end{array}$ & $\begin{array}{l}15 \\
(N=2)\end{array}$ & $\begin{array}{l}8 \\
(\mathrm{~N}=1)\end{array}$ & $\begin{array}{l}0 \\
(\mathrm{~N}=0)\end{array}$ & $\begin{array}{l}0 \\
(\mathrm{~N}=0)\end{array}$ & $\begin{array}{l}0 \\
(\mathrm{~N}=0)\end{array}$ & $\begin{array}{l}0 \\
(\mathrm{~N}=0)\end{array}$ \\
\hline $\begin{array}{l}\text { I participate in } \\
\text { cultural } \\
\text { practices of my } \\
\text { own groups, } \\
\text { such as special } \\
\text { food, music or } \\
\text { customs. }\end{array}$ & $\begin{array}{l}62 \\
(\mathrm{~N}=8)\end{array}$ & $\begin{array}{l}69 \\
(N=9)\end{array}$ & $\begin{array}{l}31 \\
(\mathrm{~N}=4)\end{array}$ & $\begin{array}{l}23 \\
(\mathrm{~N}=3)\end{array}$ & $\begin{array}{l}8 \\
(\mathrm{~N}=1)\end{array}$ & $\begin{array}{l}8 \\
(\mathrm{~N}=1)\end{array}$ & $\begin{array}{l}0 \\
(\mathrm{~N}=0)\end{array}$ & $\begin{array}{l}0 \\
(\mathrm{~N}=0)\end{array}$ \\
\hline $\begin{array}{l}\text { I feel a strong } \\
\text { attachment } \\
\text { toward my } \\
\text { own ethnic } \\
\text { group. }\end{array}$ & $\begin{array}{l}69 \\
(N=9)\end{array}$ & $\begin{array}{l}77 \\
(N=10)\end{array}$ & $\begin{array}{l}23 \\
(\mathrm{~N}=3)\end{array}$ & $\begin{array}{l}15 \\
(\mathrm{~N}=2)\end{array}$ & $\begin{array}{l}8 \\
(\mathrm{~N}=1)\end{array}$ & $\begin{array}{l}8 \\
(\mathrm{~N}=1)\end{array}$ & $\begin{array}{l}0 \\
(\mathrm{~N}=0)\end{array}$ & $\begin{array}{l}0 \\
(\mathrm{~N}=0)\end{array}$ \\
\hline $\begin{array}{l}\text { I feel good } \\
\text { about my } \\
\text { cultural or } \\
\text { ethnic } \\
\text { background }\end{array}$ & $\begin{array}{l}92 \\
(\mathrm{~N}=12)\end{array}$ & $\begin{array}{l}85 \\
(\mathrm{~N}=11)\end{array}$ & $\begin{array}{l}8 \\
(\mathrm{~N}=1)\end{array}$ & $\begin{array}{l}15 \\
(\mathrm{~N}=2)\end{array}$ & $\begin{array}{l}0 \\
(\mathrm{~N}=0)\end{array}$ & $\begin{array}{l}0 \\
(\mathrm{~N}=0)\end{array}$ & $\begin{array}{l}0 \\
(\mathrm{~N}=0)\end{array}$ & $\begin{array}{l}0 \\
(\mathrm{~N}=0)\end{array}$ \\
\hline
\end{tabular}

When asked if students were active in organizing social groups that included mostly members of their own ethnic group, eight students from Poor Folks (62\%) strongly agreed, and four students (31\%) agreed (see Table 63). Six students (46\%) from Knowledge College strongly agreed and four students (31\%) from Knowledge College agreed. 
Six students (46\%) from Knowledge College responded that they strongly agreed to this statement. Four students (31\%) responded that they agreed, and three students (23\%) responded that they disagreed.

Students were asked if they had a clear sense of their ethnic background and what it meant for them. Students from both colleges overwhelming strongly agreed with this statement. Ten students (77\%) from Knowledge College strongly agreed with this statement, and nine students (69\%) from Poor Folks College agreed with this statement (see Table 63). Moreover, three students (23\%) from Knowledge College and 4 students (31\%) from Poor Folks College agreed with this statement (see Table 63).

Students were asked if they thought a lot about whether their lives will be affected by being a member of their ethnic group. At Poor Folks College, 12 students (92\%) either strongly agreed or agreed with this statement compared to a total of eight students (62\%) who strongly agreed or agreed at Knowledge College. Furthermore, four students (31\%) from Knowledge College reported that they disagreed with this statement compared to only one student (8\%) from Poor Folks College who disagreed with this statement (see Table 63).

When asked if they were happy that they were members of the groups they belonged, thirteen students (100\%) from Poor Folks College either strongly agreed or agreed with this statement, and thirteen students (100\%) from Knowledge College either strongly agreed or agreed with this statement.

Students were asked if they had a strong sense of belonging to their own ethnic groups (see Table 63). Ten students (77\%) from Poor Folks College reported that they strongly agreed with this statement compared to nine students (69\%) from Knowledge College who agreed with this statement. However, four students (31\%) from Knowledge College agreed with this 
statement compared to two students (15\%) from Poor Folks College (see Table 63). One student (8\%) from Poor Folks College responded that he disagreed with this statement.

Students were asked if they understood what their ethnic group membership meant to them. Overall, 17 students (65\%) responded that they strongly agreed with this statement. Nine students (69.0) were from Knowledge College, and 8 students (62\%) were from Poor Folks College (see Table 63). Nine students (35\%) from both colleges agreed with this statement. Five students (38\%) were from Poor Folks College and four students (31\%) were from Knowledge College (see Table 63).

When asked if students had talked with others to learn more about their own ethnic group, seven students (54\%) from Poor Folks College agreed with this statement compared to six students (46\%) at Knowledge (see Table 63). Five students (38\%) from Poor Folks College agreed with this statement, and five students (38\%) from Knowledge College agreed with this statement. One student (8\%) from Poor Folks College disagreed with this statement (see Table 63).

When asked if students had pride in their ethnic groups, twenty-three students (88\%) from both colleges strongly agreed with this statement. Twelve students (92\%) were from Poor Folks College and 11 students (88\%) were from Knowledge College responded that they strongly agreed (see Table 63).

Students were asked if they participated in cultural practices of their own groups which include special foods, music, or customs. Nine students (69\%) from Poor Folks College responded that they strongly agreed that they participated in cultural practices, and 8 students (62\%) from Knowledge College responded that they strongly agreed with the statement (see Table 63). Two students (15\%) from Poor Folks College responded that they agreed with this 
statement, and four students (31\%) from Knowledge College responded that they agreed with this statement (see Table 63).

When questioned about having a strong attachment toward their own ethnic group, a total of 19 students (38\%) from both colleges strongly agreed with this statement, and a total of six students (23\%) from both colleges agreed with this statement (see Table 63).

Students were asked if they felt good about their culture or ethnic background (see Table 61). A total of 21 students (81\%) from both colleges strongly agreed with this statement and a total of four students (15\%) from both colleges disagreed with this statement (see Table 63).

\section{Synthesis of Multigroup Ethnic Identity Measure}

With regard to survey items one, two, four, eight, and ten, ethnic identity search, students from both colleges expressed that they do talk to other about their culture, item number eight, and they do participate in cultural practices of their own groups that involve special music, food, and customs, item number ten. However, when examining items one and two, students from Poor Folks College overwhelmingly reported that they spend time trying to find out more about their cultures, and that they are active in organizations or social groups that include mostly members of their ethnic groups. This researcher believes that it is important to note that students who come from a lower socio-economic household report they are searching more for their ethnic identities.

With regard to survey items three, five, six, seven, nine, eleven, and twelve, affirmation, belonging, and commitment, students from Knowledge College tended to have responses that strongly agreed or agreed and that were slightly higher than the students from Poor Folks College. This researcher feels that it is important to note that those students who reported a high socio-economic status tended to answer that they were more affirmed and felt a belonging 
to their ethnic group. Furthermore, these findings are similar to the responses from the protocol where students from Poor Folks College had more students report that they had experienced more incidences of being stereotyped and had been treated differently because of their ethnicity. Overall, the survey results confirmed the answers from the protocol questions that proved that Hispanic students continue to have strong bonds with their families, are aware of their culture and its practices and want to learn more about their ethnicity. 


\section{Chapter Seven: Summary, Conclusion, and Recommendations for Future Practice and Research}

\section{Summary and Major Findings}

Two community colleges were used as case studies for this qualitative research dissertation. A total of 26 students were interviewed for this study. All interviews were conducted on the campuses where the students attended college. All students were classified as Hispanic according to their demographics provided by their respective colleges. All students had completed a minimum of 12 credit hours and were working toward a two-year degree or reported that they were transferring to a college to pursue a four-year degree. Sixteen of the students interviewed were non-traditional students. One of the schools was located 20 miles from a major city; however, it was still in an extremely rural setting, and the other school was located in a rural area.

The majority of the students interviewed worked full-time, and many of the students interviewed had children or reported having family duties at home. Several of the students interviewed had a current residence in South America, but they were attending college in America to obtain a degree from the U.S. which would enable them to get better jobs once they returned home.

The majority of the students lived at home with their parents or with their spouses and children. Several students reported that they lived with their parents but also had children of their own. In order for them to attend college, these students reported that their parents helped by babysitting for them. Only one student interviewed reported that she and her husband were financially secure for her to attend college without family assistance.

Most students interviewed chose to attend their respective colleges because of proximity to their homes. Participants reported that because of family obligations, they lived at home and 
commuted to school. Moreover, students reported that they attended their respective colleges because of the low cost of tuition. It is important to note that only one of the colleges provided student housing, but none of the students interviewed at that college lived in that housing.

Students at both schools reported that the interaction with faculty members had an enormously huge impact on their decisions to remain in school. Students reported that many faculty members encouraged them to attend tutoring sessions and writing workshops. Furthermore, students reported that having the opportunity to e-mail professors outside of the classroom was extremely helpful because they were able to ask questions once the class was over. It was apparent to this researcher that without this interaction with faculty, many of these students would not have remained in college.

The majority of the students reported that they were attending college so they could have opportunities to get better employment which would allow them a more substantial income. As previously stated, none of the students interviewed at Poor Folks College had parents who had graduated from college. These students knew that to change their current economic situations, they must have some kind of skill. Students from both colleges reported that their mothers were most influential in pushing their children to get college degrees, but students at Poor Folks College actually commented that their mothers did not want them to "wear our their bodies" like their fathers did, and one mother commented that she wanted her daughter to live in a house like the ones she cleans.

Two students reported that they participated in sports; however, the majority of the students interviewed were not participating in any type club or organization on campus. None of the students interviewed were participating in a club or organization that involved minority 
students or had anything that recognized their culture with the college campus. Consequently, students reported that they were not aware of other Hispanic students on campus.

Although students did not report any type of racism or discrimination on their respective campuses, they did report incidences which occurred within the communities in which they resided. One student commented that he had been stopped by the police six times, but he had never received a ticket. This student commented that he was not speeding, but he believed that he was being stopped because of his ethnicity. Again, these incidences did not happen on the college campus.

Students interviewed reported that if given the opportunity, they would teach others about the foods and celebrations in their cultures. In addition, students reported that they would teach others about their families' histories and the close relationships they have with their family members.

All of the students interviewed reported that they were satisfied with the schools they were attending and would continue in their schools until they completed their degrees. Most students reported that they planned to complete their degrees and then transfer to another college to complete their four-year degrees.

\section{Conclusion}

As previously discussed in chapter three, the framework for this qualitative study was based on Tinto’s (1993) theory pertaining to retention in college. The interview protocol designed by this researcher asked participants questions that provided meaningful answers to each of the research questions.

This researcher learned that students were academically supported in both colleges. For example, students discussed that they e-mailed their professors, went to tutoring programs 
because of their professors, and one student even reported that his professor video-taped his class so this student could get needed information. Furthermore, students reported that they felt comfortable approaching faculty members outside of the classroom and were confident that their instructors cared about their progress. In addition, students reported that their colleges provided tutoring and writing workshops. Furthermore, school personnel were available at the libraries at both schools to assist students with assignments. Tinto (1993) discusses that students' decisions to remain in college depended upon their integration into the academic environment at their institutions. This aligns with the students' responses which indicated that their instructors were devoted to assisting them academically. Furthermore, students discussed that they were able to approach professors outside of the classroom. This again aligns with Tinto's (1993) theory that students must be integrated academically into the institution's environment. Castellanos and Jones (2003) state that a network and a need for mentoring students on the college campus is essential for student persistence. Students reported that they were encouraged by their instructors to attend workshops where school personnel and other students could assist them with their assignments. Again, this coincides with the literature review in that students must be academically acclimated with the college atmosphere. Students at both colleges also reported that their classes were challenging, but that they were still able to pass these classes. One student explained that the courses were not so demanding, but that sometimes students just simply did not complete their assignments.

Although students at both colleges reported having a strong rapport with faculty members, students at both institutions commented that they did not feel that they fit into the college culture socially. For example, several students at Knowledge College reported that the café was a popular place where students gathered and "hung out" and watched sporting events. 
However, none of these students had ever gone to the café to watch an event. Moreover, several students at Knowledge College reported that the African American population attending college sat together at the café, and the White population sat together. These students reported that although students got along with each other on campus, races were segregated. Consequently, these Hispanic students did not feel as though they belonged to a group on campus. Tinto (1993) discussed that for students to have the full college experience, they must be socially acclimated with the college as well as academically. Pascarella and Terenzini (2005) discuss that programs and activities for students to fit in the college as individuals must be provided. They suggest that organizations such as clubs memberships, participation in peer activities, and college-sponsored activities are essential to make students have a social comfort level within the institution. These students reported that after they finished their classes, they either went home or to work. They did not socialize with other students on campus.

Students from Poor Folks College reported that although they worked with students in group projects in their classes, they did not socialize with these students for non-academic events. These students reported that they went home or to work after their classes. Furthermore, these students reported that Poor Folks College did have a large number of African American students who attended the college, but that they did not socialize with this group. Moreover, these students reported that they wish they knew more Hispanic students on campus. Although these students reported that they would complete their degrees, they reported that they had family members who supported them outside of the college environment. Consequently, it is this researcher's opinion that students relied on faculty members and their families and did not depend on finding a "group” or “culture” on campus. These responses support the argument in the literature that many minority students attend community colleges because they do not have to 
leave home. However, it is also evident that these students do not obtain the entire college experience because they are not at all acclimated with the college life outside of the classroom.

After completing the cross-site analysis, the researcher concluded the following major points. Emergent themes that affect the Hispanic culture when transitioning from secondary education to higher education were established with regard to each research question. These themes are identified in this chapter to help bridge the gap that exists with Hispanic students in higher education.

\section{Research question 1.}

What internal influences affect Hispanic students to attend college?

a. How do parents and other family members or peers of Hispanic students encourage their children to attend college?

b. What are the expectations of the family once their son or daughter attends college?

Nora and Cabrera (1996) discuss that parent support and encouragement is critical when students are deciding to pursue a college education. Furthermore, although students may have negative experiences while attending college, as long as they know that they are supported by their parents and families, many students can overcome these obstacles and continue pursuing their college degrees (Nora \& Cabrera, 1996). Moreover, students who know that have positive reinforcement from their parents at home, are more likely to remain in college.

Laanan (2000) reports that the extent of family influence directly affects where students will attend college and success that students will have once they enroll in college. Hernandez (2000) discusses that Hispanic students who have families who are familiar with the college structure will experience more success when they enter college. This was evident as the 
researcher interviewed students from different schools and learned that those students who had parents who had attended college were much more involved with their children's programs and were much more influential in encouraging their children to pursue four-year degrees.

Students from both colleges reported that their parents influenced them to attend college, and that the support and encouragement they received from their families was critical when helping them decide to attend college. Many of these students commented that they were attending these particular colleges because they were close to their homes. These responses reflect research completed by Laanan (2000) that showed that Hispanic students were much more likely to choose a college near their homes in order to keep the existing family ties and also support family needs.

\section{Research question 2.}

What external influences and supports do Hispanic students obtain from high schools?

a. What programs helped these students with transition to their higher education?

b. How are Hispanics made aware of opportunities such as grants and financial aid while attending high school?

c. What individuals in the public school encourage Hispanic students to consider college as an option? How do they encourage them?

Although family support is critical for Hispanic students when they are attending college, external influences also play a major role when assisting students in transferring from secondary education to college. Teachers play a tremendous role in helping students become aware of necessary programs and paperwork that exist to enter colleges. For example, teachers tend to have knowledge of programs that different colleges offer and may act as the liaison who shares that information with students. Kirst and Venezia (2004) report that teachers have one of the 
larger roles when it comes to providing information to students about colleges and their programs. Furthermore, many times, students need recommendations and do not know how to complete the necessary paperwork for scholarships and financial aid that is needed for students to attend college. Students rely on the daily interaction with the teachers to obtain critical information needed for college admittance (Kirst \& Venezia, 2004).

Because students often have to rely on information provided by their teachers, they may not be receiving accurate information for available scholarships and grants that they may be eligible. School guidance counselors, teachers, other students, college fairs, high school visitations, and high school newspapers are just a few sources where students may be able to obtain information regarding college (Tinto, 1993). Unfortunately, many times this information slips through the cracks, and students are not made aware of vital information that they need for college.

This research was evident as a number of students who were interviewed reported that they had no help from school guidance counselors. Only one student reported that she had been on a tour of a college when she was in high school. Most students reported that they relied on their parents, friends, family members, and other school personnel who had some college experience to complete necessary paperwork. Therefore, this researcher believes that students need more assistance through secondary schools to obtain current information.

\section{Research question 3.}

What supports and services did students obtain from the community college?

Because community colleges meet the needs of minority students who tend to choose to stay at home and close to their families, the number of minority students attending these colleges is increasing (Aragon, 2000). Community colleges often provide the tools necessary for these 
students to attend college and remain close to home. This information from the literature is proven from student responses when asked what resources they use at their colleges. For example, students from both colleges reported that they did not have computers and other necessities for completing assignments at their homes, but were able to use college libraries to complete assignments as well as get assistance from school personnel. Students also reported that they used the writing labs and tutoring services provided by the college. Furthermore, many of the students interviewed indicated that they did not have parents who could help them with their academics at home, so they had to rely on resources and school personnel provided by the college to complete their assignments. Students reported that interaction with faculty members was instrumental in their success in their classes.

\section{Research question 4.}

How socially integrated are students in the community college?

The social climate of the college atmosphere has a direct impact on the student's ability to remain in college and reach attainment (Pascarella \& Terenzini, 2005). Because students may enter a college environment that embodies a high White population, that college must provide programs and activities that involve social arenas for Hispanic students are essential to keep these students in school (Pascarella \& Terenzini, 2005). Many times, college campuses do not have an understanding of minority cultures, and consequently, these students may feel isolated on campus (Castellanos \& Jones, 2003). Braxton, Hirschy, and McClendon (2004) report that college campuses, where the White population is the dominant population, must provide some kind of cultural enclave of affinity group of students who share the same culture. Tinto (1997) reports that if this environment does not exist for students or is not created for students, they may not feel accepted on the campus and consequently may leave. 
Only one student interviewed reported that she was involved in a club that involved minority students. However, this club was sponsored by the community, not the college. None of the other students interviewed reported that they were involved or knew of any other types of clubs or organizations on their campuses that were geared toward minority students.

Consequently, students from both colleges reported that they did not spend any time after their classes on the campus. Only two students who reported that they were involved in sports talked about interacting with people outside of the classroom environment or in the libraries. Although both schools had a place where students could buy food, watch TV and socialize, none of the Hispanic students interviewed used these facilities. However, this researcher feels that it is important to note that the school where she completed her pilot study had dorms located in the center of campus. This researcher feels that because students who were interviewed in her pilot study lived on campus, they were much more socially acclimated to the college environment.

\section{Research question 5.}

How integrated are students academically in the community college?

O’Meara and Braskcamp (2005) discuss the gap that exists between the faculty member and the student. They report that with early retirement programs and the hiring of part-time and non-tenured track faculty, this gap in widening. Furthermore, Tinto (1993) reports that students’ persistence in college is directly tied to the academic integration that students have with the faculty members of the college.

As this researcher interviewed students, she learned that students attending these colleges worked very closely with its faculty. Students reported that they not only enjoyed their classes, but that they had close contact and relationships with their instructors. As previously stated, one instructor was video-taping his class because one of his students was unable to attend class 
because of a work schedule. Furthermore, students reported that they were able to e-mail instructors when they did not understand an assignment, and that instructors actually persuaded them to go to the tutoring center so they could pass their classes.

\section{Research question 6.}

What challenges do Hispanic students encounter as new students in higher education?

With regard to challenges, students overwhelmingly reported that finances were a constant challenge while they were attending college. These responses support the research that states that many time the parents of these students do not have the high paying jobs that many of the parents of their White counterparts do, and therefore, these students are much more concerned with paying for tuition. In addition, because most Hispanic families do not have monies in reserve to draw from for their children's educations, students must constantly worry about whether or not they are going to qualify for financial aid or when their Pell grants are going to run out. Although Tinto (1993) reports that students who apply for financial assistance are more likely to earn their degrees, he also points out that these students are often distracted from their class assignments because they are worried about their financial needs.

Students also reported that a challenge they encountered was that their work schedules were demanding at times, and caused them to miss their classes. One student commented that he would have graduated last year, but that he had to work and could not take the amount of classes that he needed to graduate. Consequently, this student's Pell grant expired, so he struggled even more to pay his college tuition. Students reported that they had families that they were obligated to support before they could work on their assignments. 


\section{Research question 7.}

How committed are students to their career goals and the completion of their community college degree?

All students interviewed reported that they are committed to completing their college degrees. Moreover, the majority of students interviewed reported that they were committed to transferring to another college and completing their four-year degrees. It is important to remember, though, that all students interviewed were identified as "successful” college students when this researcher initially contacted their institutions. Tinto (1993) emphasizes that an individual commitment must have goal and institutional commitment. These students who were interviewed, for the most part, had support from their families and also had support from their instructors at their respective institutions. Hernandez (2000) stresses those students who are provided opportunities to work with the faculty, administrators, and participate in curricular activities are more likely to develop a sense of belonging to the college community. These experiences were evident with the students this researcher interviewed.

\section{Recommendations for Future Practice}

The first recommendation for future practice is that middle and high school administrators identify students, at least beginning in the $9^{\text {th }}$ grade, who could be encouraged to consider enrolling in a college or university. These students should take the appropriate classes necessary for college admission. If school personnel at the secondary level begin identifying and tracking students, then these students will have an advantage when they begin high school of taking classes that align with the college curriculum. Although planning is difficult and faculty members are overloaded, school systems must get more involved in the long range plan of their students instead of focusing only on the immediate task at hand. For example, school systems 
should begin planning college visitation for students in the $8^{\text {th }}$ grade. Monies should be used to provide experiences through field trips and visitations to colleges allow students to experience first-hand what a college campus looks like. By exposing students to college campuses while they are in middle school, students may see that attending college is an attainable goal. This will allow students who have never been out of their towns and cities opportunities to explore an educational environment outside of their immediate schools.

The second recommendation for future practice is that high school teachers and counselors should carefully assess college-bound students including Hispanics to insure that they have the necessary skills to enter college. Too many times, Hispanic students enter college and are forced to take remedial classes. Consequently, they do not receive and credits for classes they have taken. Teachers and counselors must assess students and create tutoring sessions that are devoted to reading and math that will give students more time to concentrate on these critical skills that are crucial in order to pass standard college admittance exams.

The third recommendation for future practice is that representatives from rural areas in both secondary and college levels need to work with representatives from urban areas to determine best practices for the increasing number of Hispanic students about to enter the collegiate world.

The fourth and final recommendation for future practice is that community colleges must create clubs and organizations for Hispanic students to join. If students feel that they have some sense of belonging, they are more likely to stay. If community colleges begin developing clubs and organization that invite minority students, then perhaps some of these students would be able to create their own comfort zones. Creating clubs that focus on minority students would allow students to meet others students with the same ethnic backgrounds, customs, and traditions. This 
would enhance the environment for students and make them feel more accepted into the social atmosphere of the college environment. Consequently, students would remain in college and graduate.

\section{Recommendations for Future Research}

The first recommendation for future research is that a more in-depth study that involves interviewing high school guidance counselors to determine what types of services and programs their schools offer to assist Hispanic students to attend college should be completed. Perhaps by interviewing guidance counselors, awareness for the need to develop these programs will arise. Guidance counselors have so much work put upon them, and unfortunately, it does not involve working directly with students. Counselors need to be given more time to work with students within the school setting to help students learn about opportunities that exist with college applications, FAFSA forms, scholarships, and other programs that may provide opportunities for students to attend college.

A second recommendation is to complete a more in-depth study that involves investigating high school systems at the administrative level to determine what types of programs and services their school systems offer. Perhaps if more school systems were aware of what other systems are doing to help their students, this information can be shared and used. For example, counties in the inner cities currently offer more programs than those in the rural areas. However, with the growing Hispanic population, school systems in the rural settings are about to experience an increase with this population. By completing a study with administrators, these programs could be discussed and implemented at the state level to provide opportunities for all students, not just those in the inner cities. Furthermore, if programs were more uniform throughout the state level and trickled to the county levels, then students who tend to move from 
school to school would have a smoother transition and know what to expect when entering a new school.

The third recommendation for future research is to explore programs that exist for Hispanic students nationwide. If information was shared from other colleges around the country, colleges could use this information and incorporate successful programs in their institutions. Perhaps by using this information, students could have more social groups in their institutions that would allow them to participate in programs and activities that would promote their cultures.

The fourth and final recommendation for future research is to complete an in-depth study which would involve another minority group such as African American. By completing this study, the researcher could compare the responses provided by another minority group to determine similarities and differences that exist between the two different groups.

As this dissertation study has illustrated, more work must be completed in both the secondary and college levels of education to help assist Hispanic students with not only the transition to college, but to obtain vital information that will provide information about colleges and information to help assist them both financially. Furthermore, school systems must work closer together to ensure that Hispanic students are aware of choices they have and programs that colleges offer. Moreover, although most universities and four-year colleges provide activities and social programs for minority students, many community colleges do not. Ultimately, secondary school systems and colleges must be aware of the needs of their minority students in order to keep them in school, transition to college, and eventually graduate with a college degree. 


\section{References}

Aragon S. R. (2000). Beyond access: Methods and models for increasing retention and learning among minority students. (Available from the ERIC Document Reproduction Service No. ED 99-CO-0010).

Arbona, C. \& Novy, D.M. (1990). Hispanic college students: Are there within-group differences? Journal of College Student Development, 32(4), 334-341.

Arellano, A.R. \& Padilla, A.M. (1996). Academic invulnerability among a select group of Hispanic university students. Hispanic Journal of Behavioral Sciences, 18(4), 485-507.

Arnold, K. (1993). The fulfillment of promise: Minority valedictorians and salutatorians. Review of Higher Education, 16(3), 257-283.

Barton, P. (2004). Why does the gap persist? Educational Leadership, 62(3), 8-13.

Braxton, J.M. \& Hirschy, A.S. (2004). Reconceptualizing antecedents of social integration in student departure. Buckingham, U.K.: Open University Press.

Braxton, J.M., Hirschy, A.S., \& McClendon, S.A. (2004). Understanding and reducing college student departure. ASHE-ERIC Higher Education Report No. 3, Volume 30. Washington, DC.

Cabrera, A.F., Nora, A., \& Castaneda, M.B. (1993). Economic influences on persistence reconsidered. Journal of Higher Education, 64(2), 123-137.

Carnegie Foundation for the Advancement of Teaching (2009). The Carnegie Classification of Institutions of Higher Education. Retrieved December 1, 2009 from http://classifications.carnegiefoundation.org/ 
Castellanos, J. \& Jones, L. (2003). Latina/O undergraduate experiences in American higher education: The majority in the minority. Sterling, Virginia: Stylus Publishing.

Center for Community College Student Engagement (2009). 2005 Institutional Reports. Retrieved January 2, 2010 from http://www.mecc.edu/atd/2005ccsse_survey/Reports.htm Creswell, J.W. (1994). Research design: Qualitative and quantitative approaches. Thousand Oaks, CA: Sage.

Fraenkel, J.R. \& Wallen, N.E. (2000). How to design and evaluate research in education. New York: McGraw-Hill.

Fern. A.O. (2006) Two-year colleges. Lawrenceville, NJ: Thomson Peterson Publishing. Gandara, P. (2004). The crisis in the education of Hispanic students. Retrieved December 8, 2009 from http://www.nea.org/home/17404.htm

Gloria, A.M., Riechmann, T.R., \& Rush, J.D. (2000). Issues and recommendations for teaching in an ethnic/culture-based course. Teaching of Psychology, 27(2), 102-107.

Hale, F.W. (2004). What makes diversity work in higher education. Sterling, Virginia: Stylus Publishing.

Haro, R., Rodriguez, G., \& Gonzalez, J.L. (1994). Hispanic persistence in higher education: A 1994 survey of University of California and California State University Chicano/Hispanic students. Paper presented at the Hispanic Issues Forum, San Francisco.

Hernandez, J.C. (2000). Understanding the retention of Hispanic college students. Journal of College Student Development, 41(6), 575-588. 
Hernandez, J.C. (2002). A qualitative exploration of the first-year experience of Hispanic college students. NASPA Journal, 40(1), 69-84.

Horn, L., and Berger, R. (2004). College persistence on the rise? Changes in 5-year degree completion and postsecondary persistence rates between 1994 and 2000 (NCES 2005-156). U.S. Department of Education, National Center for Education Statistics. Washington, DC: U.S. Government Printing Office.

Hurtado, S., Carter, D.F., \& Spuler, A. (1996). Hispanic students transition to college: Assessing difficulties and factors in successful college adjustment. Research in Higher Education, 37(2), 135-157.

Kirst, M. \& Venezia, A. (2004). From high school to college: Improving opportunities for success in postsecondary education. San Francisco: Jossey-Bass.

Kurlaender, M. (2006). Choosing community college: Factors affecting Hispanic college choice. New Directions for Community Colleges, 1(133), 7-16.

Laanan, F.S. (2000). Two year college students’ degree aspirations. Paper presented at the Association for Institutional Research Annual Forum, Cincinnati, Ohio.

Longerbeam, S.D., Sedlacek, W.E., \& Alatorre, H.M. (2004). In their own voices: Hispanic student retention. NASPA Journal, 41(3), 538-550.

MacDonald, V. \& Garcia, T. (2003). Historical perspectives on Hispanic access to higher education. In J. Castellanos \& L. Jones (Eds.), Majority in the minority: Expanding the representation of Hispanic faculty, administration and students in higher education. Sterling, Virginia: Stylus Publishing. 
Mallette, B., \& Cabrera, A. (1991). Determinant of withdrawal behavior: An exploratory study. Research in Higher Education, 32(2), 179-194.

McDonough, P.M. (1997). Choosing colleges: How social class and schools structure Opportunity. Albany, NY: State University of New York Press.

Merriam, S. B. (2001). Qualitative research and case study applications in education. San Francisco: Jossey-Bass.

National Center for Education Statistics (2009). The nation’s report card: National assessment of educational progress. Retrieved December 8, 2009 from http://nces.ed.gov/nationsreportcard/

Nora, A. (1993). Two-year colleges and minority students’ aspirations: Help or hindrance? In J. Smart (Ed.), Higher education: Handbook of theory and research, IX, 212-247.

Nora, A. (2003). Access to higher education for Hispanic students: Real or illusionary. In J. Castellanos \& L. Jones (Eds.), Majority in the minority: Expanding the representation of Hispanic faculty, administration and students in higher education. Sterling, Virginia: Stylus Publishing.

Nora, A. \& Cabrera, A.F. (1996). The role of perceptions of prejudice and discrimination on the adjustment of minority students to college. Journal of Higher Education, 67(2), 119-148.

Nora, A., Cabrera, A.F., Hagedorn, L.S., \& Pascarella, E.T. (1996). Differential impacts of academic and social experiences on college-related behavioral outcomes across different ethnic and gender groups at four-year institutions. Research in Higher Education, 37(4), 427-452. 
Nora, A. \& Lang, D. (1999). The impact of psychosocial factors on the achievement, academic and social adjustment, and persistence of college students. Paper presented at the annual meeting of the Association for the Study of Higher Education, San Antonio, TX.

Nora, A. \& Wedham, E. (1991). Off-campus experiences: The pull factors affecting freshman-year attrition on a commuter campus. Paper presented at the annual meeting of the American Educational Research Association, Chicago.

O’Meara, K. \& Braskamp, L. (2005). Aligning faculty reward systems and development to promote faculty and student growth. National Association of Student Personnel Administrators (NASPA) Journal, 42(2), 223-240.

Orfield, G. \& Ashkinaza, C. (1991). The closing door: Conservative policy and Black opportunity. Chicago: University of Chicago Press.

Pascarella, E.T. \& Terenzini, P.T. (2005). How college affects students. San Francisco: Jossey-Bass.

Patton, M.Q. (2002). Qualitative research and evaluation methods. Thousand Oaks, CA: Sage.

Pernick, D. (2007). House of Representatives passes College Student Reform Act of 2007. Retrieved December 10, 2009 from http://lideres.nclr.org/content/article/detail/2774/

Phillippe, K.A., \& Patton, M. (2000). National profile of community colleges: Trends and statistics. Retrieved September 24, 2004 from http://www.newhorizons.org/strategies/multicultural/rodriguez.htm 
Phinney, J. (1992). The Multigroup Ethnic Identity Measure: A new scale for use with adolescents and young adults from diverse groups. Journal of Adolescent Research, 7, 156-176.

Rampey, B.D., Dion, G.S., and Donahue, P.L. (2009). NAEP 2008 Trends in Academic Progress (NCES 2009-479). National Center for Education Statistics, Institute of Education Sciences, U.S. Department of Education, Washington, D.C.

Reid, G.W. \& Filipp, L. (2008). 2008 Minority Achievement Report. Retrieved December 5, 2009 from http://mhec.maryland.gov/highered/about/meetings/edpolicymeetings/2008/09-1008/2008minorityachievementreportmemo.pdf

Rendon, L.I. \& Hope, R.O. (1996). Educating a new majority: Transforming America's educational system for diversity. San Francisco: Jossey-Bass.

Rendon, L.I, Jalomo, R., \& Nora, A. (2001). Minority student persistence. In J. Braxton (Ed.), Rethinking the departure puzzle: New theory and research on college student retention. Nashville: Vanderbilt University Press.

Rendon, L.I. \& Nora, A. (1997). Student academic progress: Key data trends. Report prepared for the National Center for Urban Partnerships, Ford Foundation, New York.

Richardson, R. C., Jr. \& Skinner, E. F. (1992). Helping first-generation minority students achieve degrees. In L. S. Zwerling \& H. B. London (Eds.), First-generation students: Confronting the cultural issues. New directions for community colleges (No. 80. pp.29-43). San Francisco: Jossey-Bass. 
Roberts, R., Phinney, J., Masse. L., Chen, Y., Roberts, C., \& Romero, A. (1999). The structure of ethnic identity in young adolescents from diverse ethnocultural groups. Journal of Early Adolescence, 19, 301-322.

Rodriguez. A. (2002) The Hispanic dilemma: what are we doing about it? Retrieved September 24, 2004, from http://www.newhorizons.org/strategies/multicultural/rodriguez.htm.

Strauss, A. \& Corbin, J. (1990). Basics of qualitative research: Grounded theory procedures and techniques. London: Sage.

Swail, W.S., Cabrera, A.F., Lee, C., \& Williams, A. (2005). Hispanic students and the educational pipeline. Retrieved December 10, 2009 from http://www.educationalpolicy.org/pdf/HispanicIII.pdf

Terenzini, P., Rendon, L., Upcraft, M., Millar, S., Allisong, K., Gregg, P., \& Jalomo, R. (1994). The transition to college: Diverse students, diverse stories. Research in Higher Education, 35(1), 57-73.

Tinto, V. (1975). Dropout from higher education: A theoretical synthesis of recent Research. Review of Educational Research, 45, 89-125.

Tinto, V. (1993). Leaving college: Rethinking the causes and cures of student attrition ( $2^{\text {nd }}$ ed.). Chicago: The University of Chicago Press.

Tinto, V. (1997). Classrooms as communities: Exploring the educational character of student persistence. The Journal of Higher Education, 68(6), 599-623. 
Tinto, V., and Love, A. G. (1995). A Longitudinal Study of Learning

communities at LaGuardia Community College, Office of

Education Research and Improvement, Washington, DC. (ERIC

Document Reproduction Service No. ED 380178).

Upcraft, M.L, Gardner, J.N., \& Barefoot, B.O. (2005). Challenging and supporting the first-year student: A handbook for improving the first year of college. San Francisco: Jossey-Bass.

Venezia, A., Kirst, M.W., and Antonio, A.L. (2003). Betraying the college dream: How disconnected K-12 and postsecondary education systems undermine student aspirations. Stanford, CA: Stanford Institute for Higher Education Research.

White House Initiative on Educational Excellence for Hispanic Americans (1999).

Latinos in education: Early childhood, elementary, secondary, undergraduate, graduate. Washington, DC: ED 440817.

Yin, R. K. (2003). Case study research: Design and methods (3rd ed.). Thousand Oaks, CA: Sage. 


\section{Appendix A}

Letter to Request Institutional Site Approval

\section{WestVirginiaUniversity.}

College of Human

Resources \& Education

Date

Address

Dear Dr.

I am working on my doctorate in education leadership at West Virginia University. My dissertation research involves looking at programs and services that may have enabled, helped or assisted Hispanic students to decide to attend college. The purpose of this study is to determine what, if any programs and services in high school, helped influence Hispanic students to attend college and programs and services that may exist on college campuses that help student stay in college. I will also look at factors regarding family influences on barriers that students may have experienced when deciding to enter college.

In order to gather this information, I am seeking your permission to conduct a qualitative study to interview Hispanic students attending \{institution\}. Students' identities, school location, and students' responses will be kept confidential. All interviews will be tape recorded and kept confidential. No specific student or family data will be reviewed or reported.

Results from this study will hopefully assist both secondary schools and colleges to work together to provide a more uniform and smoother transition for Hispanic students to attend college.

Should you need further details, a complete prospectus can be made available for your review. I thank you for your support of my efforts, and should you have further concerns or questions, please feel free to contact me at 304-813-0286 or Laura.holland@acps.k12.md.us.

Respectfully,

Laura Holland

Doctoral Student

West Virginia University 


\title{
Appendix B
}

\author{
Case Study Participant Invitation Letter
}

\section{Date}

Dear Student:

You are being asked to participate in a case study I am conducting in partial fulfillment of the requirements of a doctoral course at West Virginia University. The purpose of my study is to learn more about your college experiences at \{institution\} as a Hispanic student.

I would like to ask you to participate in a brief interview, which will take approximately 30-40 minutes, as well as a 15-question survey. Your responses will be kept anonymous. This interview will be audio taped and transcribed. After transcription, the tapes will be destroyed. No identifying comments will be used in transcription of interview discussions. Your participation is strictly voluntary, and you do not have to answer every question I ask. You may withdraw from the study at any time. If you choose not to participate in this study, your class standing, grades, or job status will not be affected. If you have any questions of concerns, please call Laura Holland at 304-788-0854 or email her at laura.holland@acps.k12.md.us.

I am delighted to have the opportunity to work with you and look forward to gaining insight into issues faced by Hispanic students in college. Thank you for this opportunity.

Sincerely,

Laura Holland 


\author{
Appendix C \\ Letter to Request Permission to Use MEIM \\ WestVirginiaUniversity. \\ College of Human \\ Resources \& Education
}

Dr. Phinney,

Hello, my name is Laura Holland. I am a doctoral student at West Virginia University. I am currently working on my prospectus and am hoping to defend my first three chapters in August. I am currently an 11th grade English teacher in Allegany County, Maryland. Although we do not currently have a high number of Hispanic students enrolled in our school, we are experiencing an increase of Hispanic students annually. I would like to gain a better understanding on how to assist these students with the transition from secondary school to higher education.

My goal is to interview Hispanic students in community colleges in the state of Maryland. I will be conducting an interview with students who have been enrolled in college for two consecutive semesters to try to determine what programs/supports may exist on campus that help students to remain in college.

After I complete the interview, I would like to follow up with the MEIM in order to gain a better understanding of how students my perceive themselves and how this perception affects them in college.

It is my understanding that I need your permission to use this measure. I am asking that you grant me permission to use the MEIM in my work. I appreciate your time and effort.

Sincerely,

Laura Holland

Doctoral Candidate at WVU

laura.holland@acps.k12.md.us

304-813-0286 


\section{Appendix D \\ Letter Template Granting Permission for Use of MEIM}

(on institutional letterhead)

Dear Laura,

There are several version of the MEIM available. I recommend either the widely used 1999 version (attached) or the revised shorter version, published as Table 1, in my 2007 article (with Anothony Ong) in the Journal of Counseling Psychology. You are welcome to use either in your research.

Sincerely,

Jean Phinney 
Appendix E

Letter to Request Institutional Approval for Pilot Study

\section{WestVirginiaUniversity.}

College of Human

Resources \& Education

Dr. Kerry O’Dell

101 Fort Avenue

Potomac State College

Keyser, WV 26726

August 30, 2010

Dear Dr. O’Dell:

I am working on my doctorate in education leadership at West Virginia University. My

dissertation research involves looking at programs and services that may have enabled, helped or assisted Hispanic students to decide to attend college. The purpose of this study is to determine what, if any programs and services in high school, helped influence Hispanic students to attend college and programs and services that may exist on college campuses that help student stay in college. I will also look at factors regarding family influences on barriers that students may have experienced when deciding to enter college.

In order to gather this information, I am seeking your permission to conduct a pilot study to interview Hispanic students attending Potomac State College. Students’ identity, school location, and students' responses will be kept confidential. All interviews will be tape recorded and kept confidential. No specific student or family data will be reviewed or reported. Because this is a pilot study, at the end of the interview, I would like to discuss, with each participant the interview protocol and follow-up identity measurement to make sure that the information was presented in a clear and concise manner. Results from this study will hopefully assist both secondary schools and colleges to work together to provide a more uniform and smoother transition for Hispanic students to attend college.

Should you need further details, a complete prospectus can be made available for your review. I thank you for your support of my efforts, and should you have further concerns or questions, please feel free to contact me at 304-813-0286 or Laura.holland@acps.k12.md.us.

Respectfully,

Laura Holland

Doctoral Student

West Virginia University 
Appendix F

Letter Template from Institution Granting Permission for Pilot Study

(Institution Letterhead)

(Date)

Laura Holland

Rt. 1 Box 226

Keyser, WV 26726

Dear Ms. Holland,

I am writing to indicate my support for your doctoral pilot study at Potomac State

College. I will provide you with a list of names and addresses for 15 of our students who: 1)

are Hispanic students; 2) will be enrolled for a program of study leading to a degree or

certification; 3) are either part- or full-time students; 4)are at least 18 years of age; and 5) are

male and female traditional and non-traditional students.

I understand that you will send each student a letter outlining your study and invite him or her to participate. I also understand that you will arrange interview times which should last no longer than 45 to 60 minutes. You have agreed to emphasize to the students that their participation is strictly voluntary and that they have the right to not respond to any item. Student participation in your study will not affect their class standing, grades, or membership in any student organization or athletic team. You have also agreed that you will not release students’ names or any other identifying information as their responses are to remain confidential.

Sincerely, (Name)

(Institution) 


\author{
Appendix G \\ Pilot Participant Invitation Letter
}

August 14, 2010

Dear Student:

You are being asked to participate in a qualitative pilot study I am conducting in partial fulfillment of the requirements of a doctoral course at West Virginia University. The purpose of my study is to learn more about your experiences at Potomac State College as a Hispanic student.

I would like to ask you to participate in a brief interview, which will take approximately 30-40 minutes, as well as a 15-question survey. Your responses will be kept anonymous. This interview will be audio taped and transcribed. After transcription, the tapes will be destroyed. No identifying comments will be used in transcription of interview discussions. Your participation is strictly voluntary, and you do not have to answer every question I ask. You may withdraw from the study at any time. If you choose not to participate in this study, your class standing, grades, or job status will not be affected. If you have any questions of concerns, please call Laura Holland at 304-788-0854 or email her at laura.holland@acps.k12.md.us.

I am delighted to have the opportunity to work with you and look forward to gaining insight into issues faced by Hispanic students in college. Thank you for this opportunity.

Sincerely,

Laura Holland 


\section{Appendix H}

\section{Interview Protocol}

Script: Hello, my name is Laura Holland. I am working on my doctoral degree in Educational Leadership Studies at West Virginia University. I want to learn more about your experiences in the community college and how you made decisions about attending college. I am going to ask you some questions about your educational and cultural background. If you do not feel comfortable with any of the questions, please let me know and we will move on to the next one. Also, please note that your participation in this study does not affect your grades nor does it affect your status in college. Thank you.

\section{Interview Questions}

1. What is your gender?

2. What is your age?

3. What was your primary language spoken where you were raised?

4. What is your major?

5. How many credits have you completed?

6. What is your grade point average at this community college??

7. Are you hoping to obtain a two year degree, a certificate, or possibly transfer to another school for a four year degree?

8. Where are you from? (town, city, state, country)

9. Do you currently live at home with your parents?

10. How would you describe the place where you were raised? (Probe: Additional information)

11. Describe your parents’ educational background. (Probe: Mother’s and Father's highest degree)

12. Who influenced you decision to attend college? (Probe: Mother, Father, Sister, Brother, friends) How did they influence your decision to attend college?

13. Now that you are in college, what are your family's expectations?

14. What made you decide to attend Community College? 
15. What types of challenges did you face as you made your decisions to attend this college?

16. (A) How did your high school provide support or what programs in high school helped you decide to go to college? (B) How did your guidance counselors help you?

17. (A) How did you become aware of financial aid and grants in high school? (B) Are you receiving financial aid or any type of grant?

18. (A) What college resources have you utilized your first year to help you in college? (B) How did these resources help you?

19. Have you had any experiences at which made you think about or be more aware of your ethnic background? For example, experiences where you thought you were treated primarily as a Hispanic rather than an individual.

20. Have you ever thought about whether being Hispanic affects your life right now? That is, have you ever thought about whether there are things that are easer or harder for you because you are Hispanic?

21. (A) How socially connected do you feel with students at this community college? How about faculty?

22. What types of clubs and/or organizations have you participated in at this community college?

23. If you had the chance to teach other people at culture, what would you teach them?

24. (A) Since you have enrolled at Community College, how much have you enjoyed your classes? (B) How much do the instructors of your classes care about you and your progress?

25. What obstacles or challenges have you experienced as a Hispanic attending college?

26. Have your feelings about yourself as a Hispanic changed since you have attended college?

27. How successful have you been this in college? (Can you describe some of your successes?)

28. (A) What are you career goals? (B) How certain are you about your career goals?

29. When do you anticipate completing your degree program?

30. Do you see yourself enrolling in consecutive semesters until you finish your degree? 


\section{Appendix I \\ Multigroup Ethnic Identity Measure (MEIM)}

In this country people come from many different countries and cultures, and there are many different words to describe the different backgrounds or ethnic groups that people come from. Some examples of the names of ethnic groups are Hispanic or Hispanic, Black or African American, Caucasian or White, Italian American, and many others. These questions are about your ethnicity or you ethnic group and how you feel about it or react to it.

Please fill in: In terms of ethnic group, I consider myself to be

Use the numbers below to indicate how much you agree or disagree with each statement.

\section{(4) Strongly agree (3) Agree (2) disagree (1) Strongly disagree}

1-I have spent time trying to find out more about my ethnic group such as its history, traditions, and custom.

\section{(4) Strongly agree (3) Agree (2) disagree (1) Strongly disagree}

2-I am active in organizations or social groups that include mostly members of my own ethnic group.

\section{(4) Strongly agree (3) Agree (2) disagree (1) Strongly disagree}

3-I have a clear sense of my ethnic background and what it means for me.

\section{(4) Strongly agree (3) Agree (2) disagree (1) Strongly disagree}

4-I think a lot about how my life will be affected by my ethnic group membership.

\section{(4) Strongly agree (3) Agree (2) disagree (1) Strongly disagree}

5-I am happy that I am a member of the group I belong to.

\section{(4) Strongly agree (3) Agree (2) disagree (1) Strongly disagree}

6-I have a strong sense of belonging to my own ethnic group.
(4) Strongly agree
(3) Agree
(2) disagree
(1) Strongly disagree

7-I understand pretty well what my ethnic group membership means to me.
(4) Strongly agree
(3) Agree
(2) disagree
(1) Strongly disagree 
8-In order to learn more about my ethnic background, I have often talked to other peole about my ethnic group.

\section{(4) Strongly agree (3) Agree (2) disagree (1) Strongly disagree}

9-I have a lot of pride in my ethnic group.

\section{(4) Strongly agree (3) Agree (2) disagree (1) Strongly disagree}

10-I participate in cultural practices of my own group, such as special food, music or customs.

\section{(4) Strongly agree (3) Agree (2) disagree (1) Strongly disagree}

11-I feel a strong attachment toward my own ethnic group.

\section{(4) Strongly agree (3) Agree (2) disagree (1) Strongly disagree}

12-I feel good about my cultural or ethnic background.

\section{(4) Strongly agree (3) Agree (2) disagree (1) Strongly disagree}

13-My ethnicity is

(1) Asian or Asian American, including Chinese, Japanese, and others

(2) Black or African American

(3) Hispanic or Hispanic, including Mexican American, Central American, and others

(4) White, Caucasian, Anglo, European American; not Hispanic

(5) American Indian/Native American

(6) Mixed; Parents are from two different groups

(7) Other (write in):

14-My father's ethnicity is

(1) Asian or Asian American, including Chinese, Japanese, and others

(2) Black or African American

(3) Hispanic or Hispanic, including Mexican American, Central American, and others

(4) White, Caucasian, Anglo, European American; not Hispanic

(5) American Indian/Native American

(6) Mixed; Parents are from two different groups

(7) Other (write in):

15-My mother's ethnicity is 
(1) Asian or Asian American, including Chinese, Japanese, and others

(2) Black or African American

(3) Hispanic or Hispanic, including Mexican American, Central American, and others

(4) White, Caucasian, Anglo, European American; not Hispanic

(5) American Indian/Native American

(6) Mixed; Parents are from two different groups

(7) Other (write in):

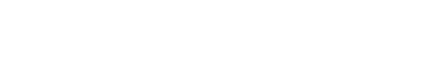

